\title{
REFINED COMPARATIVISM IN CONSTITUTIONAL LAW
}

\author{
David Fontana
}

This Article considers the possible uses of comparative constitutional law in American constitutional interpretation. Surveying the debates about the uses of comparative constitutional law at the Founding, and tracing these debates to contemporary times by looking at the role of comparative constitutional law in the history of the U.S. Supreme Court, David Fontana suggests that a moderate, workable practice of using comparative constitutional law is consistent with the original intention of the Founders and has some precedent in the case law of the U.S. Supreme Court.

This Article lays out a "refined comparativist" approach, whereby a court would consider comparative constitutional law only when faced with a "hard case," the comparative constitutional law can add something distinctive to American constitutional interpretation, and the contextual differences between the United States and the country the American court is considering borrowing from are slight. This Article then defends this refined comparativist model, paying particular attention to several strands of contemporary constitutional scholarship, before applying refined comparativism to address the constitutionality of hate speech.

I. TyPOlOGY OF COMPARATIVE CONSTITUTIONAL LAW USES ................................ 544

A. A History of the Uses of Comparative Constitutional Law

in American Judicial Opinions................................................................... 544

B. Typology of Past Usage ................................................................................. 550

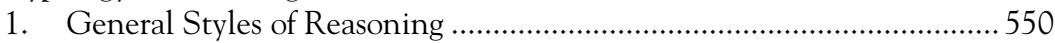

2. Role in the Legal Argument of a Judicial Opinion ...............................552

II. REFINED COMPARATIVISM: THE FRAMEWORK .................................................. 556

A. When a Court Should Consider Using Comparative Constitutional Law.

B. How a Court Should Use Comparative Constitutional Law:

The Process of Trial and Appeal

III. THE VIRTUES OF REFINED COMPARATIVISM

* D.Phil. candidate, Oxford University, 2004; J.D. candidate, Yale Law School, 2004; B.A., University of Virginia, 1999. Many thanks to Henry J. Abraham, Bruce A. Ackerman, Akhil Reed Amar, Guido Calabresi, William N. Eskridge, Jr., Martin S. Flaherty, Paul Gewirtz, David Halberstam, Adam Hickey, A.E. Dick Howard, Vicki C. Jackson, Vasan Kesavan, George Klosko, Nick Levin, Gerard N. Magliocca, Caleb Nelson, David M. O’Brien, Robert Stevens, Kate Stith, Mark Tushnet, and William Twining for their assistance in this project. Of course, the usual disclaimer applies: All arguments and mistakes are my own. 
A. Pragmatic Virtues of Refined Comparativism ......................................... 566

B. Normative Virtues of Refined Comparativism ....................................... 572

IV. A HiSTORY OF REFINED COMPARATIVISM......................................................... 574

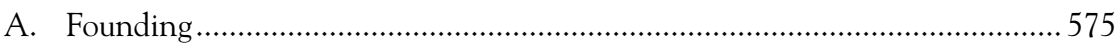

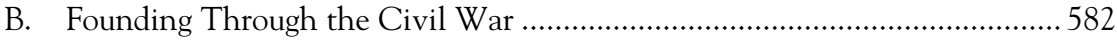

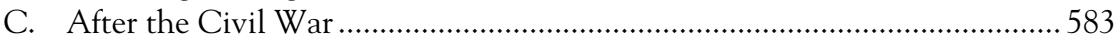

1. Relations Between Levels and Branches of Government:

Federalism and Separation of Powers................................................ 583

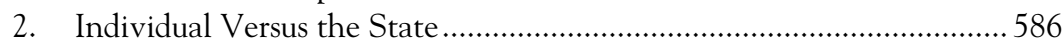

V. REFINED COMPARATIVISM AND CONTEMPORARY

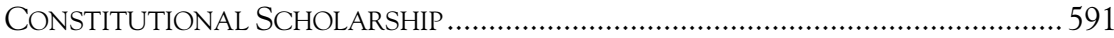

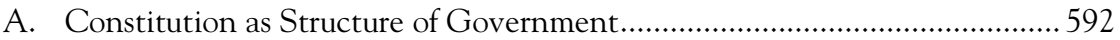

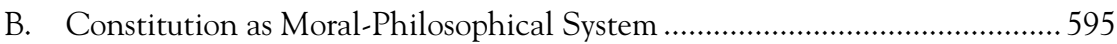

C. Constitution as Tradition/National Character............................................. 599

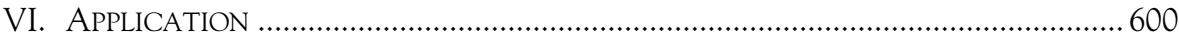

A. Canada, Hate Speech, and Refined Comparativism .....................................64 604

1. The Virtues of Looking to Canadian Constitutional Law on Hate Speech ....................................................................................... 606

2. Criticisms of Looking to Canadian Constitutional Law on Hate Speech.

B. Europe, Hate Speech, and Refined Comparativism ...................................612

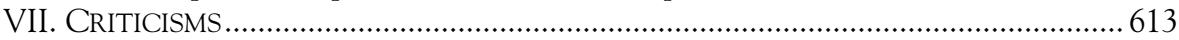

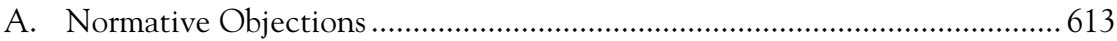

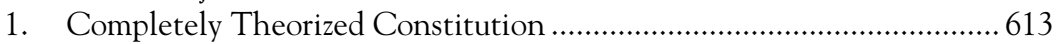

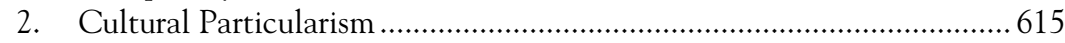

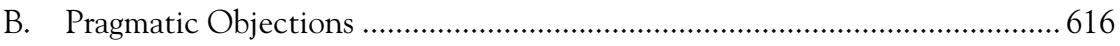

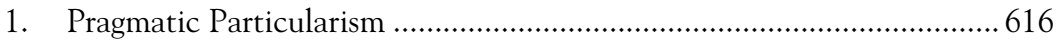

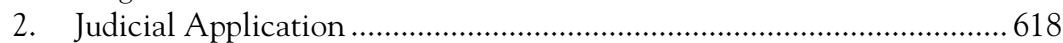

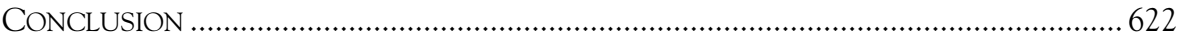

\section{INTRODUCTION}

In his memoirs, entitled Present at the Creation, ${ }^{1}$ Dean Acheson described the feeling at the State Department in the aftermath of World War II:

In a sense the postwar years were a period of creation .... Moreover, the state of the world in those years and almost all that happened during them was wholly novel within the experience of those who had to deal with it.... [F] or those who acted this drama did not know, nor do any of us yet know, the end. ${ }^{2}$

1. Dean Acheson, Present at the Creation: My Years in the State DEPARTMENT (1969).

2. Id. at xvii. 
A similar feeling echoes throughout American constitutional scholarship as it decides what to make of the "rise of world constitutionalism." Never before has American constitutional scholarship seriously considered advocating the use of comparative constitutional law ${ }^{4}$ in American constitutional cases. Now, some scholars are finally focusing on the age-old issue of legal borrowing within the American constitutional context. Being "present at the creation," Acheson reminds us, means one does not know what will happen in the future. This Article argues that the future should include an extension of the study of legal transplants ${ }^{6}$ to the constitutional context: American courts, in deciding constitutional cases, should sometimes refer to comparative constitutional law materials.

A number of U.S. Supreme Court opinions, authored by various Justices, have referred to comparative constitutional law materials. ${ }^{7}$ However, while the role of international law in domestic courts has been a subject of great interest in the academic literature, ${ }^{8}$ there has been no American

3. Bruce Ackerman, The Rise of World Constitutionalism, 83 VA. L. REV. 771 (1997).

4. An important question to answer in looking at the role of comparative constitutional "law" in American constitutionalism is what exactly is the "law" that judges can look to in foreign countries? Traditionally, comparative law has focused only on legal texts in foreign countries. Thus, leading comparativists, like Rodolfo Sacco and Günter Frankenberg in Europe, and Alan Watson in the United States, focused on comparative legal texts. ALAN WATSON, LEGAL TRANSPLANTS: AN APPROACH TO COMPARATIVE LAW 9 (1974); Günter Frankenberg, Critical Comparisons: Re-Thinking Comparative Law, 26 HARV. INT'L L.J. 411 (1985); Rodolfo Sacco, Legal Formants: A Dynamic Approach to Comparative Law, 39 AM. J. ComP. L. 1 (1991). As William Ewald describes it, comparative legal scholars have typically believed that "law includes statutes and case reports and decisions of administrative agencies- that is, the sorts of things that working attorneys characteristically consult in their day-to-day practice. But law does not include, except peripherally, legal history or the writings of philosophers, or the speculations of academics." William Ewald, Comparative Jurisprudence (I): What Was It Like to Try a Rat?, 143 U. PA. L. REV. 1889, 2107 (1995).

The judge interested in comparative constitutional law would be well advised to try to abide by this focus on legal texts and look mostly or only at written legal documents-legislation, judicial opinions-because the judge is best trained to read and understand those documents. The judge looking for insights on how a law in a foreign country has worked in actuality can look for information on that in formal legal documents, but also could look to studies of comparative constitutional sociology. As a general rule, however, the refined comparativist judge should stick to the examination of formal texts because "a full comparison... of any two legal systems ... requires the use of techniques unfamiliar to lawyers." RICHARD A. POSNER, LAW AND LEGAL THEORY IN ENGLAND AND AMERICA 70 (1996).

5. ACHESON, supra note 1 .

6. WATSON, supra note 4. By legal transplants, I mean borrowing legal ideas, doctrines, and other legal information from foreign countries.

7. Infra notes 20-43 and accompanying text.

8. The leading articles in this area of scholarship include, for example, Curtis A. Bradley, Breard, Our Dualist Constitution, and the Internationalist Conception, 51 STAN. L. REV. 529 (1999); Curtis A. Bradley \& Jack L. Goldsmith, Customary International Law as Federal Common Law: A Critique of the Modern Position, 110 HARV. L. REV. 815 (1997); Curtis A. Bradley, The Treaty Power and American Federalism, 97 MiCH. L. REV. 390 (1998); Curtis A. Bradley, The 
scholarship examining when and how judges should use the constitutional insights of other countries. Indeed, there are many casebooks that examine constitutional development in other individual countries, ${ }^{9}$ or constitutional development in all countries, ${ }^{10}$ but the debate about legal transplants does not appear in constitutional scholarship, with the exception of a handful of recent articles: Mark Tushnet's article on the criteria for measuring the success of constitutional borrowings ${ }^{11}$ and on the propriety of constitutional borrowings into American constitutional law based on certain legal theories, ${ }^{12}$ Sujit Choudhry's article examining the different styles of comparative constitutional law reasoning in countries around the world, ${ }^{13}$ and articles that examine the wisdom of constitutional borrowings in specific doctrinal contexts (such as Christopher McCrudden's article looking at the uses of comparative law in human rights jurisprudence, ${ }^{14}$ and Vicki Jackson's articles on the uses of comparative constitutional law to resolve different doctrinal issues in American constitutional law ${ }^{15}$ ). In other words, no scholar has yet directly posed the important question: Should American constitutional law borrow from comparative constitutional law? In this Article, the question is posed and then answered by building upon a latent practice in American constitutional adjudication: American judges have occasionally been using, and should continue to use, comparative constitutional law in a certain kind of way, a way I call "refined comparativism." This Article systematizes and provides a workable framework to improve upon this history of refined comparativism by suggesting criteria for when it should be used, how it can be used so that

Treaty Power and American Federalism, Part II, 99 MICH. L. REV. 98 (2000); and David M. Golove, Treaty-Making and the Nation: The Historical Foundations of the Nationalist Conception of the Treaty Power, 98 MICH. L. REV. 1075 (2000).

9. E.g., DONALD P. KOMMERS, THE CONSTITUTIONAL JURISPRUDENCE OF THE FEDERAL Republic of Germany (1997); Alec Stone, The Birth of Judicial POlitics in France: THE CONSTITUTIONAL COUNCIL IN COMPARATIVE PERSPECTIVE (1992).

10. MAURO CAPPELlETTI \& William COHEN, COMPARATIVE CONSTITUTIONAL LAW (1979); VICKI C. JACKSON \& MARK TUSHNET, COMPARATIVE CONSTITUTIONAL LAW (1999); WALTER F. MURPHY \& JOSEPH TANENHAUS, COMPARATIVE CONSTITUTIONAL LAW (1977).

11. Mark Tushnet, Returning with Interest: Observations on Some Putative Benefits of Studying Comparative Constitutional Law, 1 U. PA. J. CONST. L. 324 (1998).

12. Mark Tushnet, The Possibilities of Comparative Constitutional Law, 108 YALE L.J. 1225 (1999).

13. Sujit Choudhry, Globalization in Search of Justification: Toward a Theory of Comparative Constitutional Interpretation, 74 IND. L.J. 819 (1999).

14. Christopher McCrudden, A Common Law of Human Rights?: Transnational Judicial Conversations on Constitutional Rights, 20 OXFORD J. LEG. STUD. 499 (2000).

15. Vicki C. Jackson, Ambivalent Resistance and Comparative Constitutionalism: Opening Up the Conversation on "Proportionality," Rights and Federalism, 1 U. PA. J. CONST. L. 583 (1999) [hereinafter Jackson, Ambivalent Resistance]; Vicki C. Jackson, Narratives of Federalism: Of Continuities and Comparative Constitutional Experience, 2001 DUKE L.J. (forthcoming). 
it is as efficacious as possible, and why American judges ruling on constitutional matters should care about comparative constitutional law at all.

Part I of this Article catalogs the ways in which comparative constitutional law can be used in American judicial decisions. This Part looks at the different styles of comparative constitutional reasoning, and the different roles that such reasoning can play in the legal argument of a judicial opinion. In order to form a common language to better explain what exactly the Article is defending, this Part highlights the various ways in which one can use comparative constitutional law in American judicial decisions. Before arguing that the Court should and can "use" comparative constitutional law in a particular way, this Part attempts to show the various ways in which courts can "use" comparative constitutional law. Part I also begins to show that in fact the Court in a wide range of cases has already used comparative constitutional law.

Part II of this Article introduces the idea of "refined comparativism," a type of rulebook about when American courts adjudicating constitutional cases should use comparative constitutional law and how they should structure the process of legal borrowing within the context of a trial or an appeal. Parts I and II together constitute the essence of "refined comparativism." Part I discusses the various ways an American court deciding a constitutional issue can use comparative constitutional law, and Part II discusses when it is appropriate for an American court to use comparative constitutional law and how a court should go about using comparative constitutional law to make up for possible institutional limitations.

The next three Parts defend this vision of refined comparativism, demonstrating that it has historical support, fits with several important schools of contemporary constitutional scholarship, and will add something to contemporary American constitutional law. Part III discusses some of the benefits of refined comparativism. Part IV demonstrates that the version of refined comparativism sketched in Parts II and III in fact has some historical support. Focusing mostly on the Founding and on Supreme Court decisions, American constitutional law has from the outset used comparative constitutional law, both in the writing of the Constitution and in its interpretation. Part $\mathrm{V}$ tests the acceptability of the vision of refined comparativism, not according to original constitutional intention or subsequent practice, but rather according to various contemporary theoretical approaches to American constitutional law.

After sketching this vision of refined comparativism and defending it, Part VI then turns to a particular case and applies refined comparativism to illustrate the virtues it can have. Part VI applies the refined comparativist 
method implicit in past cases to one particular case, R.A.V. v. St. Paul, ${ }^{16}$ a case dealing with the constitutionality of a state hate crimes statute. Part VII refutes some potential criticisms of the refined comparativist vision, normative and pragmatic.

\section{Typology of COMPARATive CONSTItUTIONAL LAW USES}

Before we can examine whether American judges should cite to and use comparative constitutional law, and how they can do so most effectively, we must first examine the different styles of comparative constitutional reasoning in American constitutional law and the different roles that these styles of reasoning can play in the legal structure of a judicial decision. This Part focuses on exactly what role comparative constitutional law could play in a judicial decision, and on the different general styles of comparative constitutional reasoning. Of course, there are many different versions of comparative constitutional "law" that American judges can look to-formal legal texts, studies of law in action, and so on. ${ }^{17}$

\section{A. A History of the Uses of Comparative Constitutional Law in American Judicial Opinions}

The enterprise of comparing the laws of different countries is not at all new. Aristotle and Solon engaged in perhaps the first examples of comparative legal study, and in the eighteenth and nineteenth centuries, the Societe de Legislation Compare in France and the Society of Comparative Legislation in England engaged in lengthy studies of the legislation of different countries. In the American context, since the beginning of the Republic there has been an effort to spread the American constitutional philosophy around the world. As A.E. Dick Howard and I have attempted to show, this "constitutional advising" has taken on many different forms over the course of American history. ${ }^{18}$ However long Americans have been willing to make constitutional suggestions to others, they have very rarely been willing to listen to others' constitutional suggestions. This provincialism stands alone now that, with the end of the Cold War, the traffic in constitutional ideas in most countries includes both imports and exports

16. 505 U.S. 377 (1992).

17. Supra note 4.

18. A.E. Dick Howard \& David Fontana, The Changing Role of the American Constitutional Advisor (Nov. 2001) (unpublished manuscript, on file with author); see also CONSTITUTIONALISM AND RIGHTS: THE INFLUENCE OF THE UNITED STATES CONSTITUTION ABROAD (Louis Henkin \& Albert J. Rosenthal eds., 1990) (cataloging the influence of the U.S. Constitution on different countries' constitutional systems). 
from other sophisticated liberal constitutional democracies. The South African Bill of Rights, for example, empowers that country's courts to look abroad when interpreting it. ${ }^{19}$

Despite the resistance of American constitutional scholarship to consider constitutional borrowings, the Supreme Court has in fact not demonstrated all that much "ambivalent resistance" ${ }^{20}$ to using comparative constitutional law. The Court has been using comparative constitutional law from its inception, despite well-publicized remarks ${ }^{21}$ like Justice Antonin Scalia's argument in Printz v. United States ${ }^{22}$ that "comparative analysis [is] inappropriate to the task of interpreting a constitution, though it was of course quite relevant to the task of writing one, ${ }^{23}$ to which Justice Stephen Breyer, the Court's most ardent comparative constitutionalist, responded that comparative constitutional law "may ... cast an empirical light on the consequences of different legal solutions to a common legal problem." ${ }^{24}$

Indeed, almost every Justice now on the Court has used comparative constitutional law in their opinions. Although these usages of comparative constitutional law differ both in their general style of reasoning and in their exact role in the Justices' opinions, the willingness of the Court to occasionally look abroad at the same time American constitutional scholarship

19. S. AFR. CONST. of 1996, ch. 2, § 39(1)(b)-(c) (defining the use of foreign and public international law); id. ch. 14, § 231 (defining the mechanisms used to determine the legal status of international agreements). The interim Constitution of South Africa included similar provisions. S. AFR. CONST. of 1993 (IC), ch. 3, § 35(a); id. ch. 14, § 231. Indeed, in one of its most important opinions to date, State v. Makwanyane, Judgment of June 6, 1995 (State v. Makwanyane and Another), Constitutional Court No. CCT/3/94, at 3808-B-09a, the South African Constitutional Court made reference to the constitutional opinions of other courts. President Arthur Chaskalson's opinion alone discusses rulings of the U.S. Supreme Court, e.g., id. at 405G-06D, 410G-I n.35, 415F-17B, 420E-F, 421E-22D, 434F; the Massachusetts Supreme Judicial Court, e.g., id. at 432D-E, 432F-G; the California Supreme Court, e.g., id. at 432E-F, 434F-G, 445E; the Hungarian Constitutional Court, e.g., id. at 429H-30F; the German Constitutional Court, e.g., id. at 406A, 423B-C, 438B-F, 446G, 448A; the Privy Council, e.g., id. at 420I n.3; the Canadian Supreme Court, e.g., id. at 406A-B, 423D-24A-E, 436G-38B; the Tanzanian Court of Appeals, e.g., id. at 440H-41F; the Supreme Court of India, e.g., id. at 406BC, 426G-29C; the Supreme Court of Zimbabwe, e.g., id. at 402H-I n.3, 452I n.170; the European Court of Human Rights, e.g., id. at 406D, 425F-26A, 429D, 438F-39E; and the United Nations Committee on Human Rights, e.g., id. at 406D, 424E-25F, 429E-G.

20. Jackson, Ambivalent Resistance, supra note 15, at 589 (noting how the Court has been "sometimes silently, sometimes expressly" resistant to using comparative constitutional law).

21. See Linda Greenhouse, Appealing to the Law's Brooding Spirit, N.Y. TIMES, July 6, 1997, at E4.

22. 521 U.S. 898 (1997).

23. Id. at 921 n. 11 .

24. Id. at 977 (Breyer, J., dissenting). 
has hardly even noticed developments around the world is surprising. ${ }^{25}$ Most recently, in deciding not to hear an appeal of two death penalty cases that raised the issue of whether an undue delay prior to execution constitutes cruel and unusual punishment, Justices Breyer and Clarence Thomas engaged in another debate about the uses of comparative constitutional law. Justice Breyer argued that the "Court has long considered as relevant and informative the way in which foreign courts have applied standards roughly comparable to our own constitutional standards in roughly comparable circumstances.... I believe their views are useful even though not binding." ${ }^{26}$ Justice Thomas, concurring in the denial of certiorari, argued that "were there any such support in our own jurisprudence [for Breyer's argument], it would be unnecessary ${ }^{\text {"27 }}$ for Breyer to look abroad for the answer to the case before the Court.

Justice David Souter looked to Dutch constitutional practice in Washington v. Glucksberg ${ }^{28}$ to examine arguments presented to the Court

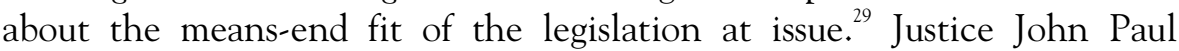
Stevens has used comparative constitutional law to decide whether a particular American legal practice was "cruel and unusual." In Thompson v. Oklahoma, ${ }^{31}$ Justice Stevens noted that the Court should look to "other nations" to confirm that it would "offend civilized standards of

25. Ackerman, supra note 3, at 772 ("[T]he global transformation [of constitutionalism] has not yet had the slightest impact on American constitutional thought."). In fairness to many scholars, Bruce Ackerman's lecture was published in 1997, well before the publication of the important Vicki Jackson and Mark Tushnet casebook and other leading articles in the field.

26. Knight v. Florida, 528 U.S. 990, 997-98 (1999) (Breyer, J., dissenting from denial of certiorari).

27. Id. at 990 (Thomas, J., concurring in denial of certiorari).

28. 521 U.S. $702(1997)$.

29. Id. at 785-87 (Souter, J., concurring).

30. U.S. CONST. amend. VIII.

31. 487 U.S. 815 (1988). This method of using comparative constitutional law to decide what constitutes cruel and unusual punishment can be traced back to Justice Arthur Goldberg's dissent from a denial of certiorari in Rudolph v. Alabama, 375 U.S. 889 (1963) (Goldberg, J., dissenting from denial of certiorari), in which he asserted that "[i]n light of the trend . . . throughout this world" the practice at issue should be struck down. Justice Goldberg made reference to a United Nations survey on the laws, regulations, and practices of countries around the world. Id. at 890-91. He argued that the combination of overwhelming international disapproval of the practice at issue, plus the McCulloch v. Maryland, 17 U.S. (4 Wheat.) 316 (1819), plea to interpret constitutions in an evolutionary manner, means that the practice at issue violates "evolving standards of decency that mark the progress of [our] maturing society." Id. at 890 (quoting Trop v. Dulles, 356 U.S. 86, 101 (1958)).

32. Id. at 830 (Stevens, J., plurality opinion). 
decency ${ }^{\prime 33}$ to execute juveniles before age sixteen. ${ }^{34}$ Justice Ruth Bader Ginsburg also joined an opinion making reference to comparative constitutional law. ${ }^{35}$

Chief Justice William Rehnquist cited to comparative constitutional law on abortion in Planned Parenthood $v$. Casey, ${ }^{36}$ and argued in the first lineitem veto case, Raines $v$. Byrd, ${ }^{37}$ that looking at foreign systems of standing helped show how an American statute might not be "irrational" 38 because foreign systems "operate[d] under one or another variant of . . a [similar] regime. ${ }^{39}$ Justice Scalia, the critic of comparative constitutional law in Printz, has in fact used comparative constitutional law in his other opinions. ${ }^{40}$ Justice Anthony Kennedy has used comparative constitutional

33. Id.

34. For a type of negative constitutional comparativism in Justice John Paul Stevens's opinions, a form of reasoning I will discuss infra note 59 and accompanying text, see, for example, Holland v. Illinois, 493 U.S. 474, 507-08 n.6 (1990), which analogized South African and Nazi Germany precedents to current efforts to determine race for legal purposes, and California v. Acevedo, 500 U.S. 565, 586 (1991) (Stevens, J., dissenting), which recognized search and seizure rules as "bulwark[s] against police practices that prevail in totalitarian regimes."

35. Nixon v. Shrink Mo. Gov't PAC, 528 U.S. 377, 403 (Breyer, J., concurring, joined by Ginsburg, J.) (concluding that the current U.S. Supreme Court First Amendment doctrine "is consistent with that of other constitutional courts facing similarly complex constitutional problems" and looking to the decisions of the European Court of Human Rights and the Canadian Supreme Court)

36. 505 U.S. 833, 945 n.1 (1992) (Rehnquist, C.J., concurring in part and dissenting in part) (citing to abortion decisions by the West German Constitutional Court and by the Canadian Supreme Court).

37. 521 U.S. 811 (1997).

38. Id. at 828 .

39. Id.

40. In Thompson v. Oklahoma, 487 U.S. 815 (1988), the Eighth Amendment case that prompted Justice Stevens to use comparative constitutional law, Justice Antonin Scalia argued that:

The practices of other nations, particularly other democracies, can be relevant to determining whether a practice uniform among our people is not merely a historical accident, but rather "so implicit in the concept of ordered liberty" that it occupies a place not merely in our mores ... [but] in our Constitution as well.

Id. at 868-69 n.4 (Scalia, J., dissenting) (citation omitted). Justice Scalia later states that "it is a Constitution of the United States of America we are expounding." Id. at 869; see also McIntyre v. Ohio Election Comm'n, 514 U.S. 334, 381 (1995) (Scalia, J., dissenting) (suggesting that the prohibition of anonymous campaign speech in foreign democracies supports prohibition in the United States). For a form of what I shall call "genealogical comparativism," or comparison based upon some form of historical linkage, see Loving v. United States, 517 U.S. 748 (1996), a case in which the Justices fought over the relevant scope of congressional and presidential power in determining the punishment for court martials. Scalia argued that English law at the time of the Founding could sometimes be relevant, although not in that particular case. Id. at 775-76 (Scalia, J., concurring). 
law in his opinions. ${ }^{41}$ Justice Sandra Day O'Connor has used comparative constitutional reasoning, ${ }^{42}$ as has Justice Thomas. ${ }^{43}$

Off the bench, members of the Court have started to confer with members of constitutional courts in other countries ${ }^{44}$ and have spoken of the need to incorporate comparative constitutional law into American constitutional law. At a press conference after meeting with members of the European Court of Justice (ECJ), Justice O'Connor stated that she would be willing to consult ECJ decisions "and perhaps use them and cite them in future decisions. " ${ }^{45}$ Justice O'Connor has elsewhere urged American lawyers appearing before the Court to cite to foreign law. ${ }^{46}$ Justice Breyer, matching his advocacy of using comparative constitutional law in his decisions, stated in the ECJ press conference with Justice O'Connor that "[l]awyers in America may cite an EU ruling to our court to further a point, and this increases the cross-fertilization of U.S.-E.U.

41. Justice Anthony Kennedy has also employed negative constitutional borrowing. See, e.g., Shaw v. Reno, 509 U.S. 630, 647 (1993) (finding that racial reapportionment "bears an uncomfortable resemblance to political apartheid"); Metro Broad., Inc. v. FCC, 497 U.S. 547, 633 n.1 (1990) (Kennedy, J., dissenting) (invoking race-conscious definitions used in Nazi Germany and South Africa).

42. For example, Justice Sandra Day O'Connor used a form of comparative constitutional law reasoning by referring to the Nuremberg Tribunals as a relevant precedent not because of their role in international law but rather because they represented the experience of a court in a foreign land. United States v. Stanley, 483 U.S. 669, 710 (1987) (O'Connor, J., concurring in part and dissenting in part) (citing the Nuremberg Tribunals as precedent).

43. Holder v. Hall, 512 U.S. 874, 907 n.14 (1994) (Thomas, J., concurring) (looking to the voting systems of many countries to assess the constitutional status of the American voting system).

44. Yale Law School's annual Global Constitutionalism Seminar brings together judges from courts with constitutional jurisdiction from around the world. Judges have also traveled around the world to meet with each other in each other's courtrooms. For example, in July 1998, a U.S. delegation that included Justices Stephen Breyer, Ruth Bader Ginsburg, Kennedy, and O'Connor traveled to meet with European judges. Stephen J. Breyer, Changing Relationships Among European Constitutional Courts, 21 CARDOZO L. REV. 1045, 1061 n.1 (2000).

45. Elizabeth Greathouse, Justices See Joint Issues with the EU, WASH. POST, July 9, 1998, at A24 (reporting on a press briefing at which Justices O'Connor and Breyer asserted that they might use and cite decisions by the European Court of Justice). Justice O'Connor has also led the Justices to meet their foreign counterparts, first from the French Conseil d'Etat, the Conseil Constitutonnel, and the Cour de Casssation, and most recently from the European Court of Justice, the European Court of Human Rights, and the German Constitutional Court. In addition, following the tragedy of September 11, 2001, in New York City, Pennsylvania, and Washington, D.C., Justice O'Connor alluded to international and comparative law in telling a New York University School of Law audience that "[i]t is possible, if not likely, that we will rely more on international rules of war than on our cherished constitutional standards for criminal prosecutions in responding to threats to our national security." Linda Greenhouse, In New York Visit, O'Connor Foresees Limits on Freedom, N.Y. TIMES, Sept. 29, 2001, at B5.

46. E.g., Sandra Day O'Connor, Our Shrinking World: Why Lawyers Need International Awareness, Keynote Address to the Union Internationale des Advocates (Sept. 3, 1997). 
ideas." ${ }^{\text {47 }}$ Chief Justice Rehnquist, speaking at a ceremony marking the fortieth anniversary of the German Basic Law, remarked that:

For nearly a century and a half, courts in the United States exercising the power of judicial review had no precedents to look to save their own, because our courts alone exercised this sort of authority. When many new constitutional courts were created after the Second World War, these courts naturally looked to decisions of the Supreme Court of the United States, among other sources, for developing their own law. But now that constitutional law is solidly grounded in so many countries, it is time that the United States courts begin looking to the decisions of other constitutional courts to aid in their own deliberative process. The United States courts, and legal scholarship in our country generally, have been somewhat laggard in relying on comparative law and decisions of other countries. But I predict that with so many thriving constitutional courts in the world today ... that approach will be changed in the near future. ${ }^{48}$

Following the lead of the Supreme Court, other American courts have used comparative constitutional law. Judge Guido Calabresi of the U.S. Court of Appeals for the Second Circuit has looked abroad for answers to difficult American constitutional questions, ${ }^{49}$ hoping for an "on-going dialogue between the adjudicative bodies of the world community." lower court judges have looked to comparative constitutional law in their opinions $^{51}$ or in their off-the-bench writings. ${ }^{52}$

47. Greathouse, supra note 45 (quoting Justice Breyer).

48. William Rehnquist, Constitutional Courts-Comparative Remarks (1989), reprinted in GERMANY AND ITS BASIC LAW: PAST, PRESENT AND FUTURE-A GERMAN-AMERICAN SYMPOSIUM 411, 412 (Paul Kirchof \& Donald P. Kommers eds., 1993). Chief Justice William Rehnquist's argument, that until recently very few countries had viable constitutional regimes, is disputable, although most scholars seem to share this opinion. E.g., CAPPELlETTI \& COHEN, supra note 10, at 13-16 (1979) (arguing that comparative constitutional law only became viable after World War II).

49. United States v. Then, 56 F.3d 464, 469 (2d Cir. 1995) (Calabresi, J., concurring).

50. Euromepa S.A. v. R. Esmerian, Inc., 51 F.3d 1095, 1101 (2d Cir. 1995).

51. For example, in United States v. Hall, 34 M.J. 695 (A.C.M.R. 1991), the U.S. Court of Military Review was forced to examine a case involving issues related to sodomy and the right to privacy. The court, using comparative constitutional law in what I shall call the "context" way, noted that "[t]he debate and uncertainty over the right to privacy are not purely American. 'There has been a sort of judical trans-Atlantic volley in privacy law .... Until the European Commission and Court of Human Rights joined in on this side most of the smashes were coming from the United States." Id. at 697 n.2 (quoting J. Michel, Homosexuals and Privacy, 138 NEW L.J. 831 (1988)).

52. Shirley Abrahmson \& Michael J. Fischer, All the World's a Courtroom: Judging in the New Millennium, 26 Hofstra L. Rev. 273 (1997); Richard A. Posner, Pragmatic Adjudication, 18 CARdozo L. ReV. 1, 13-14 (1996). Chief Justice Shirley Abrahmson sits on the Wisconsin Supreme Court, and Judge Richard Posner sits on the U.S. Court of Appeals for the Seventh Circuit. 
B. Typology of Past Usage

1. General Styles of Reasoning

An American court can use comparative constitutional law in one of two ways, depending on the relationship that the court attempts to argue exists between the "lender" country and the United States: (1) genealogical comparativism $^{53}$ or (2) ahistorical comparativism. In a system of genealogical comparativism, a court indicates that it looks to comparative constitutional law because some relationship exists between the lender country-the country supplying the idea or fact the American court is considering borrowing - and the United States.

Genealogical comparativism makes sure to note that one of the central reasons that the American court looks to comparative constitutional law is because of the historical, legal, and/or cultural relationship between that country and the United States. The most frequent use of comparative constitutional law in American constitutional adjudication arises when courts use a thin genealogical comparativism rationale, usually in the context of studying English legal history: This is the system we come from, therefore this is who we are, therefore this is relevant to interpreting our Constitution. Justice Kennedy's opinion in Loving v. United States ${ }^{54}$ illustrates this type of reasoning. In order to understand the power of Congress and of the president in determining the punishment for court martials, Justice Kennedy argued, we must examine the comparative constitutional law of England because our system derives from the English system. ${ }^{55}$ Of course, the obvious question posed by genealogical comparativism is how broadly to extend "genealogy" — what countries do we have a sufficiently close relationship with to justify constitutional borrowing? As will be discussed in Part III.B, the Court has grappled with this problem for some time. One of the many reasons American constitutional adjudication should use comparative constitutional law is because courts should have a thicker sense of genealogical comparativism-courts should be more aware that there are important historical, cultural, and legal relationships between the United States and other countries besides eighteenth and preeighteenth century England. ${ }^{56}$

53. I am of course not the first to talk about genealogical legal arguments—scholars like Sujit Choudhry have mentioned it in passing. Choudhry, supra note 13, at 865. My contribution in this Article is to describe genealogical argumentation in detail, systematizing it in the context of comparative constitutional argumentation.

54. $\quad 517$ U.S. 748 (1996).

55. Id. at 759-67.

56. Infra Part III.B. 
I will call the other form of comparative constitutional law reasoning in American opinions ahistorical comparativism. In this type of reasoning, although a historical, cultural, and legal relationship may exist between the lender country and the United States, this relationship does not form the basis for the constitutional borrowing. Rather, the American court looks to the constitutional solution of the other country for its own sake, regardless of that country's historical, legal, and cultural similarity with the United States.

Another important distinction must be drawn between positive comparativism and negative comparativism. ${ }^{57}$ Positive comparativism involves an American court looking to comparative constitutional law with approval, looking to see if American constitutional law can borrow from comparative constitutional law. ${ }^{58}$ By contrast, negative comparativism looks to comparative constitutional law as a way of devising principles of American constitutional law by testing what it is not. Negative comparativism involves looking to the failures (from the American perspective) of other constitutional regimes. ${ }^{59}$

57. This distinction should be viewed as separate from the distinction introduced above between genealogical comparativism and ahistorical comparativism. Thus, an American court can use comparative constitutional law using both genealogical comparativism and positive/negative comparativism. Likewise, a court can use comparative constitutional law using both ahistorical comparativism and positive/negative comparativism.

58. Justice Breyer's opinions in Printz v. United States, 521 U.S. 898, 976-78 (1997) (Breyer, J., dissenting), and Knight v. Florida, 528 U.S. 990, 994-98, (1999) (Breyer, J., dissenting from denial of certiorari), are examples of positive comparativism.

59. This notion of negative comparativism has similarities with the concepts developed in two articles unrelated to comparative constitutional borrowing. Vincent Blasi, The Pathological Perspective and the First Amendment, 85 COLUM. L. REV. 449 (1985) (discussing the "pathological perspective," or the use of worst-case scenarios, in the context of the First Amendment); Richard A. Primus, Canon, Anti-Canon, and Judicial Dissent, 48 DUKE L.J. 243 (1998) (discussing the use of anti-canons, or cases that serve as examples of particularly poor legal reasoning).

The U.S. Supreme Court has made reference to a number of failures or undesirable aspects of other constitutional regimes. For example, the Court in the last decade or so alone has used negative comparativism to make arguments that certain systems resemble apartheid and are therefore anathema to the U.S. Constitution. E.g., Shaw v. Reno, 509 U.S. 630, 647 (1993) (finding that racial reapportionment "bears an uncomfortable resemblance to political apartheid"); see also Metro Broad., Inc. v. FCC, 497 U.S. 547, 633 n.1 (1990) (Kennedy, J., dissenting) (invoking race-conscious definitions used in Nazi Germany and South Africa); Holland v. Illinois, 493 U.S. 474, 507-08 n.6 (1990) (Stevens, J., dissenting) (analogizing South Africa and Nazi Germany precedents to current efforts to determine race for legal purposes).

Negative comparativism has been most frequently used to analogize to restrictions on artistic, cultural, or political freedoms in other countries that would "obviously" be unacceptable in the American system. E.g., Ward v. Rock Against Racism, 491 U.S. 781, 790 (1989) ("[T]he totalitarian state[s] in our own times ... have censored musical compositions to serve the needs of the state."); Elrod v. Burns, 427 U.S. 347, 353 (1976) (noting that the patronage system was associated with the Nazi rise to power); Karlan v. City of Cincinnati, 416 U.S. 924, 926-27 (1974) (Douglas, J., dissenting) (arguing that freedom of speech sets the United States apart from 
2. Role in the Legal Argument of a Judicial Opinion

What role can comparative constitutional law play within the legal argument of a judicial opinion? Before discussing when and how an American court should cite to comparative constitutional law, we must examine what exactly the court is using comparative constitutional law to do in its opinion. Previous experimentation with comparative constitutional law has highlighted three different ways a court can use it: (1) in dicta, (2) to create a workable principle of law, or (3) to prove a "constitutional fact." ${ }^{60}$

A court using comparative constitutional law in dicta can do so in a number of ways. First of all, the court can simply use the comparative constitutional law as a way of providing context to the discussion of the facts and of the law relating to the facts. Chief Justice Rehnquist in Washington v. Glucksberg, ${ }^{61}$ for instance, uses comparative constitutional law simply to show that the issue the Court is addressing is one that many people are talking about around the world. ${ }^{62}$ Courts can use comparative constitutional law in dicta to recommend the adoption of a particular rule of law or principle, or to note a relevant constitutional fact yet not make this constitutional fact part of the decision. In this way, the courts are using comparative constitutional law the same way detailed below, but without

totalitarian countries); United States v. White, 401 U.S. 745, 764-65 (1971) (Douglas, J., dissenting) (accusing the majority of allowing a chilling effect of surveillance of the sort associated with "totalitarian countries"); Ker v. California, 374 U.S. 23, 62 (1963) (Brennan, J., dissenting in part) (finding no logical distinction between the actions of the police at issue and those "usually associated with totalitarian police"); Sweezy v. New Hampshire, 354 U.S. 234, 262 (1957) (Frankfurter, J., concurring) (quoting a "poignant" argument for academic freedom in South Africa); Brown v. Allen, 344 U.S. 443, 512 (1953) (claiming that the availability of the writ of habeas corpus is "one of the decisively differentiating factors between our democracy and totalitarian governments"); Tenney v. Brandhove, 341 U.S. 367, 381 (1951) (Black, J., concurring) (warning of the use in Argentina of congressional investigating committees to suppress dissident newspapers); Terminiello v. Chicago, 337 U.S. 1, 4 (1949) ("The right to speak freely and to promote diversity of ideas and programs is therefore one of the chief distinctions that sets us apart from totalitarian regimes.").

60. See Richard A. Posner, Against Constitutional Theory, 73 N.Y.U. L. REV. 1, 11-12 (1998) (calling for the Supreme Court to pay more attention to deciding cases based on relevant "constitutional facts"). By constitutional facts, I am using the term in a manner identical to the way it is used by Judge Posner: Constitutional facts are those facts that can be discovered by observing experience (legal and otherwise) to answer a particular legal question posed by a case. For instance, Judge Posner argues that the Supreme Court should have used constitutional facts to assess the true equality of rival educational institutions at issue in United States $v$. Virginia, 518 U.S. 515 (1996). Posner, supra, at 12-20.

61. $\quad 521$ U.S. $702(1997)$.

62. Id. at 718 n.16. For another example of comparative constitutional law as context in dicta, see CBS v. Democratic National Committee, 412 U.S. 94, 158 n.9 (1973) (Douglas, J., concurring). 
making the use of comparative constitutional law part of the actual decision of the court. ${ }^{63}$ This Article will be much more concerned with the use of comparative constitutional law to create rules and standards, ${ }^{64}$ or to help find constitutional facts, than with its use as constitutional dicta.

Courts can also use comparative constitutional law to create rules of law or principles to be applied by subsequent courts, legislatures, and executives. This use of comparative constitutional law can be roughly analogized to Kenneth Culp Davis's notion of "legislative facts." "65 Davis defined legislative facts as follows: "When an agency [or court] wrestles with a question of law or policy, it is acting legislatively ... and the facts which inform its legislative judgment may conveniently be denominated legislative facts." A court uses comparative constitutional law as a legislative fact to help it find a workable rule or standard to apply in the case before it and in future cases. ${ }^{67}$ A court may use comparative constitutional law as "legislative fact" in many different situations. ${ }^{68}$ First of all, a court may find this use of comparative constitutional law helpful when it is addressing an issue for the first time, and there are no helpful American judicial precedents. Here, using comparative constitutional law allows an American court to benefit from the accumulated experience and wisdom of another country and of the faster legal or extralegal evolution that has led to the resolution of the issue there more quickly than in this country. This approach to solving new issues is particularly appropriate in the judicial setting, in which courts are acting with few fact-finding powers and in an increasingly complex world, and so can particularly benefit from borrowing a principle that has already between tried and tested. ${ }^{69}$ Second of all, a court creating a rule or standard

63. For interesting discussions of the role of dicta, see, for example, Michael C. Dorf, Dicta and Article III, 142 U. PA. L. REV. 1997 (1994); and Neal Kumar Katyal, Judges as Advicegivers, 50 STAN. L. REV. 1709 (1998).

64. Kathleen M. Sullivan, The Supreme Court, 1991 Term-Foreword: The Justices of Rules and Standards, 106 HARV. L. REV. 22 (1992).

65. Kenneth Culp Davis, An Approach to Problems of Evidence in the Administrative Process, 55 HARV. L. REV. 364, 402 (1942).

66. Id.

67. A court may use the experience of "law in action" in other countries to help it see which principle would work, or may look to the principle that a foreign country has applied to help it come up with a principle. Again, as discussed supra note 4, refined comparativist judges should generally stick to looking at formal legal texts-judicial opinions, constitutional text-and if they can glean insights about how the law has actually worked from those opinions, then it would be less objectionable for them to use that information then it would be for them to use an article on comparative legal sociology, for example.

68. The ideal situation for using comparative constitutional law, of course, would be when all of the situations described in this discussion exist-indeed, this is the paradigmatic example of refined comparativism, discussed below.

69. For a discussion of this notion of the virtues of borrowing from comparative experience, see infra Part III. 
may use comparative constitutional law when the American sources are unclear, and therefore the constitutional answer to the question before the court is hard to find. Justice Breyer's opinion in Printz essentially uses this approach. ${ }^{70}$ Breyer argues that the issue posed by Printz is complicated and that the American sources are unclear, therefore the Court should look abroad. In these cases, comparative constitutional law can help settle difficult American constitutional questions by providing more evidence and information. Finally, an American court crafting a rule or standard may use comparative constitutional law to help it bridge the "concept" and "conception" distinction. ${ }^{71}$ The American sources may be clear enough to help guide the court somewhat (providing the court with a "concept"), but not clear enough to help the court come up with a workable rule or standard to be applied in the case before the court and in future cases ("conception"). Judge Calabresi's opinion in United States $v$. Then ${ }^{72}$ provides an example of this use of comparative constitutional law. Calabresi essentially argued that the American constitutional tradition helped us find a relevant "concept" but comparative constitutional law can help us find a workable rule or standard, the "conception," in this case the notion of suspensive vetoes utilized in Italy and Germany. ${ }^{73}$

Last of all, a court can use comparative constitutional law to help it prove a relevant constitutional fact. This frequently involves "law canvassing" ${ }^{\text {" }}$-looking to the laws of many countries to help define a term or assess

70. Justice Breyer's Printz dissent seems to argue that the American sources on federal commandeering of state executives are unclear-the constitutional text is ambiguous, and there are no clear precedents. Therefore, to help the Court reach a decision, it should use comparative constitutional insights to pick a solution that works. See Printz v. United States, 521 U.S. 898, 977 (1997) (Breyer, J., dissenting).

71. I borrow this notion of "concepts," or broader goals, and of "conceptions," or specific formulations of those goals, from a number of contemporary thinkers. STEPHEN GUEST, RONALD DWORKIN 29 (2d ed. 1997) ("Dworkin makes frequent use of a distinction between concepts and conceptions."); JOHN RAWLS, A THEORY OF JUSTICE ch. 5 (1971). The terms have their origin in W.E.B. Gallie, 56 Proceedings of the Aristotelian Soc'y 167 (1965).

72. 56 F.3d 464, 468-69 (2d Cir. 1995) (Calabresi, J., concurring).

73. Id.

74. By law canvassing, I mean using the laws of different jurisdictions to help prove a relevant constitutional fact. Justice Byron White in Bowers v. Hardwick, 478 U.S. 186 (1986), for example, looked to the laws of various states to determine the moral sentiments of Americans regarding sodomy. Id. at 192-96. A complete law canvassing in constitutional law requires the judge to look at state laws, another "intertextual" source of constitutional meaning. Because they are domestic sources of constitutional meaning, the judge should use that form of law canvassing prior to using comparative law canvassing. Indeed, this Article does not argue, and it is not essential for the vision of refined comparativism introduced in this Article, that comparative constitutional law be the primary source of "comparative" or "intertextual" insight. Thus, I fully agree with the observations of some that state constitutional law should be the "true" source of comparative constitutional insight. E.g., Akhil Reed Amar, Comparative Constitutional Law, American Style (Jan. 2000) (unpublished manuscript, on file with author). This Article argues 
the rationality or acceptability of a legal practice. This constitutional fact use of comparative constitutional law has been particularly common in cases deciding whether or not a particular legal practice was "cruel and unusual" under the Eighth Amendment. ${ }^{75}$ Another common use of comparative constitutional law is to help with the judicial analysis of relevant constitutional facts that arise in assessing a means-end fit. To see whether a given end is compelling, a court can see how the "end" has worked in other countries, or can look at other countries to see whether the means used will actually further the end, or if there are other alternatives to reach that end that have worked in other countries. Justice Souter's Washington v. Glucksberg $^{76}$ opinion uses comparative constitutional law in this way, studying Dutch constitutional practice surrounding euthanasia to argue that a given means would not produce a certain end because of the Dutch experience with a similar program. ${ }^{77}$ Also, if it is not considered pure dicta context, as mentioned above, courts can be said to use comparative constitutional law to show that a given practice at issue in a case is not entirely irrational. Rehnquist's opinion in the first line-item veto case, stating that a different practice of constitutional standing would not be

that comparative constitutional law can help judges decide constitutional cases. This Article leaves for another day the question of where on the list of relevant sources-beyond traditional sources-comparative constitutional law would rank.

For the purposes of this Article, however, the sole argument is the rather uncontroversial point that comparative constitutional law, although less relevant than mainstream traditional sources of meaning - text, history-still matters. Comparative constitutional law, among secondary sources of constitutional meaning, is particularly appropriate for the reasons presented in many places in this Article. Infra Part III. Thus, refined comparativism has obvious similarities with Myres McDougal's version of eclectic interpretive methodology. See LUNG-CHU CHEN, AN INTRODUCTION TO CONTEMPORARY INTERNATIONAL LAW: A POLICY-ORIENTED PERSPECTIVE passim (2d ed. 2000) (discussing McDougal's jurisprudential approach). Unlike McDougal's version, however, refined comparativism does visualize a clear hierarchy of relevant interpretive sources, and comparative constitutional law (though not one of the most directly relevant sources) is important to understand and use from time to time because it is a source of particular relevance and utility. Infra Part III.

75. This was the issue in the Knight v. Florida opinions by Justices Clarence Thomas and Breyer discussing the Court's denial of certiorari in a death penalty case. See also Thompson v. Oklahoma, 487 U.S. 815, 830-31 (1988) (Stevens, J., plurality opinion) (discussing the execution of juveniles); Enmund v. Florida, 458 U.S. 782, 796-97 n.22 (1982) (discussing the elimination of restrictions on felony murder in England, India, Canada, and a "number of other Commonwealth countries"); Trop v. Dulles, 356 U.S. 86, 102-03 (1958) (noting that only two of eighty-four countries surveyed used denationalization as a penalty for desertion). See supra note 31 .

76. 521 U.S. 702 (1997).

77. Id. at 785-87 (Souter, J., concurring). 
"irrational," ${ }^{78}$ is an example of this use of comparative constitutional law to help prove a constitutional fact. ${ }^{79}$

\section{REFINED COMPARATIVISM: THE FRAMEWORK}

Given that courts can use comparative constitutional law in the ways outlined in Part I, how can the trial and appeal process be structured to help a judge use comparative constitutional law in an accurate, effective manner? When should a judge use comparative constitutional law? This Part will discuss when a judge should consider using comparative constitutional law, and how the judge should go about using comparative constitutional law within a trial or appeal.

A judge should consider using comparative constitutional law when the American sources do not provide a clear answer to a question the judge must answer (whether factual or legal). The judge should use the comparative legal materials only if the contextual differences are relatively minimalif the problems faced by importing a solution or fact from another country are relatively insignificant. The judge should then consider whether the comparative materials have any comparative advantages, the paradigmatic case of when comparativism would be appropriate, or simply provide another "data point" (factual or legal). Within the framework of a trial or appeal, a judge should encourage litigants to argue comparative constitutional law to courts (when appropriate), sometimes even using expert witnesses on foreign law who can help the judge determine the relevant comparative constitutional law and its transferability. Judges who

78. Raines v. Byrd, 521 U.S. 811, 828 (1997).

79. This can be particularly helpful when the important issue in the case is whether a particular practice before the Court is "reasonable." Adkins v. Children's Hosp., 261 U.S. 525, 57071 (1923) (Holmes, J., dissenting) (arguing that the practice of other nations, including Great Britain and Australia, supported the reasonableness, and hence the constitutionality, of a minimum wage law for women that the Court struck down). The power of the state end advanced and the appropriateness of the means the state used to further that end are also examples of the possible use of comparative constitutional facts. Also, a court concerned about the larger implications and consequences of its actions (and a court that uses this type of consequential reasoning in its decisions) can look to comparative constitutional law. For example, Mark Tushnet has suggested that we could use comparative constitutional law to help judges decide about the threat posed by their own potential judicial activism. Mark Tushnet, Policy Distortion and Democratic Debilitation: Comparative Illumination of the Countermajoritarian Difficulty, 94 MICH. L. REV. 245, 249 (1995) (stating that "[w]ith the spread of constitutional review throughout the world, we now have a larger base of information on which to rest judgments about" the potential threats to democratic decisionmaking raised by judicial review).

80. For a discussion of the idea of "data points" within the context of legal studies, see, for example, David H. Kaye \& David A. Freedman, Reference Guide on Statistics, in FED. JUDICIAL CTR., REFERENCE MANUAL ON SCIENTIFIC EVIDENCE 331 (1994). 
use comparative constitutional law and solicit expert witnesses to help them do so will encourage litigants to argue and brief foreign law, thereby making the judicial use of comparative constitutional law more accurate because it will be based on a number of different sources.

\section{A. When a Court Should Consider Using Comparative Constitutional Law}

Comparative constitutional law should be viewed as a form of persuasive authority, or authority that attracts adherence as opposed to obliging it. ${ }^{81}$ As Justice Breyer noted in Knight v. Florida, ${ }^{82}$ comparative constitutional law can be "useful even though not binding." comparative constitutional law does not overwhelm all of the other potential sources of constitutional law in a judicial ruling. It just provides an additional source to help courts deal with "hard cases." order sources of constitutional meaning (text, for instance)—which I have

81. This view of some sources as persuasive rather than obligatory poses obvious problems for judicial discretion. If a judge has no obligation to use a source that we call "persuasive," then he or she might use it in a selective and inconsistent matter. This could be one plausible objection to refined comparativism - is there enough of a guide as to when judges should use comparative constitutional law, or will they simply use it when it supports their argument? This does not mean that one should not recognize the existence of persuasive authority, but rather should be vigilant in critiquing the principled and consistent use of such authority by judges.

There can be basically two main objections related to judicial capacity and refined comparativism. The first objection is the general objection to judicial discretion that arises whenever one talks about a new form of judicial power. I have several responses to this argument. First, refined comparativism is not a dangerous form of judicial discretion. It is actually one way of further limiting how a judge deals with a hard case. Second, we must recognize that judges have been using comparative constitutional law for a while, and will continue to do so, and it is better to talk openly about this usage so we can talk openly about principled limitations. Third, refined comparativism is not necessarily a prohibitively expensive and time-consuming form of judging. With the assistance of litigants and experts, a judge may actually find it a less expensive and more principled way to decide hard cases. Refined comparativism is not an idea that gives judges a new power to strike down laws. Rather, it is just a discussion of the sources that judges can use in exercising their traditional power of constitutional review.

The second judicial discretion-type objection would center on not the general role of judges in refined comparativism but rather on the role of judges using comparative materials in particular. This objection is discussed infra Part VII.B.2.

82. 528 U.S. $990(1999)$.

83. Id. at 998 (Breyer, J., dissenting from denial of certiorari); see also Thirty Hogsheads of Sugar v. Boyle, 13 U.S. (9 Cranch) 191, 198 (1815) ("The decisions of the Courts of every country ... will be received, not as authority, but with respect.").

84. Ronald Dworkin, Hard Cases, 88 HARV. L. REV. 1057 (1975). To use Frank Michelman's language, constitutional interpretation involves "multiple poles in a complex field of forces, among which judges navigate and negotiate." Frank I. Michelman, A Constitutional Conversation with Professor Frank Michelman, 11 S. AFR. J. HuM. RTS. 477, 483 (1995). My goal is simply to argue that comparative constitutional law, in those cases involving complex forces, be one pole in that field. 
not argued should be superceded by comparative constitutional law-will resolve the issue presented to a court, the case is not a "hard case," and therefore the court does not need to look to comparative constitutional law. When the American sources are clear and unambiguous, and help lead to a clearly correct answer, a court need not consult comparative constitutional law. ${ }^{85}$ However, when a case presents many difficult questions and there is no clear answer, either because of the originality of the issue presented ${ }^{86}$ or because of the conflicting directions in which the sources point, comparative constitutional law may provide additional sources of law to help a court reach an answer. Comparative constitutional law merely serves as another source outside of traditional sources of American law that helps resolve a case. Whether courts cite to classics of literature or to legal scholarship, they have frequently looked beyond the traditional domestic legal sources for answers, as they would do in refined comparativism. ${ }^{87}$ Judges would look at the case before them, and see if they can resolve it using the basic, obvious American sources. If not, then a judge can begin to consider using comparative constitutional law. This may be because the issue presented is new and evolving, ${ }^{88}$ the constitutional provision being litigated is relatively ambiguous, ${ }^{89}$ or so on. Using comparative constitutional law,

85. A court can still consult and use comparative constitutional law in the easiest of cases by using it in dicta in order to provide context, to suggest the adoption of a different principle, or to point out a constitutional fact. Another interpretation of Guido Calabresi's opinion in Then is that the American sources are in fact clear, but Calabresi wants us to consider adopting the judicial power to issue suspensive vetoes, and thus mentions the Italian and German cases. United States v. Then, 56 F.3d 464, 468-69 (2d Cir. 1995) (Calabresi, J., concurring).

86. Thus, included within the definition of "hard cases" are those cases in which a new issue is presented to a court, and even though the sources may point in one direction, there has been no practical experience with how a decision one way or another would work. Usually, however, refined comparativism would make sense when the issue is new, the sources are conflicting, and another country has greater experience with this particular issue.

87. American literature is not somehow more binding on a court than comparative constitutional law. True, American literature is a part of American culture, and therefore it expresses elements of the domestic culture that the Constitution is trying to give life to, but it is much less relevant to deciding legal cases than comparative constitutional law. Even if it is more relevant, however, that is simply authorization for the notion of "intertextualism," and comparative constitutional law would be simply lower down the list of relevant intertextual sources than literature.

It is not necessary to argue that courts should employ refined comparativism to assert that comparative constitutional law is somehow the most binding source of constitutional meaning.

88. This seems to be the thrust of Justice David Souter's use of Dutch constitutional practice in Washington v. Glucksberg, 521 U.S. 702 (1997). In that case, Justice Souter looked to Dutch practice because "[t]he day may come" when the United States gains substantial experience with the issue, but currently other countries have more experience. Id. at 786 (Souter, J., concurring).

89. See, e.g., John Hart Ely, Democracy and Distrust: A TheOry of Judicial REVIEW 11-41 (1980) (mentioning the Due Process Clause of the Fifth Amendment, the unenumerated rights language of the Ninth Amendment, and the various clauses of Section 1 of the 
even in "hard cases," should be considered optional-comparative constitutional cases are not binding precedents that a judge must consider. ${ }^{90}$

To minimize the possible difficulties of considering comparative constitutional law, a court using its insights should consider contextual differences between the lender country and the United States. ${ }^{91}$ The court should view these contextual differences on a sliding scale: The more contextual differences, the less desirable utilizing comparative constitutional law will be. For example, Justice Breyer's use of comparative constitutional law in Knight illustrates how a judge might make sure to use comparative constitutional law in situations in which the problems of constitutional ideas traveling across borders are minimized. Justice Breyer noted that the courts he was looking to had faced "roughly comparable" ${ }^{92}$ questions under

Fourteenth Amendment as examples of open-ended constitutional language). If the constitutional provision being litigated is ambiguous, and the provision itself has been and should be interpreted in a functionalist way, then comparative constitutional law may be even more relevant. An American judge can look to comparative constitutional law in that instance (for example, in the case of federalism, as in Justice Breyer's dissent in Printz v. United States, 521 U.S. 898, 976-78 (1997) (Breyer, J., dissenting)) to come up with a rule or standard that, based on the experience of the other country, leads the judge to believe that the comparative principle will further the goals or ends that the American constitutional system contemplates.

90. Once these comparative constitutional cases are used in an American judicial opinion, the judge would have the power to determine whether or not these cases themselves (and their predecessors and progeny) are binding precedent. The "minimalist" refined comparativist can simply make the American case that used comparative constitutional law the binding precedent, while the "maximalist" refined comparativist can make some or all of the comparative constitutional cases binding precedents. For a discussion of the judicial power over precedent, see, for example, Anastasoff v. United States, 223 F.3d 898 (8th Cir. 2000), which held that all judicial decisions must have precedential effect because of Article III's "judicial power" language. For critiques of this position, see Richard S. Arnold, Unpublished Opinions: A Comment, 1 J. APP. PRAC. \& Process 219 (1999); Danny J. Boggs \& Brian P. Brooks, Unpublished Opinions $\mathcal{E}$ The Nature of Precedent, 4 GreEN BAg 2d 17 (2000); Alex Kozinski \& Stephen Reinhardt, Please Don't Cite This: Why We Don't Allow Citation to Unpublished Dispositions, CAL. LAW., June 2000, at 43; Boyce F. Martin, Jr., In Defense of Unpublished Opinions, 60 OHIO ST. L.J. 177 (1999); Philip Nichols, Jr., Selective Publication of Opinions: One Judge's View, 35 AM. U. L. ReV. 909 (1986); Lauren K. Robel, The Myth of the Disposable Opinion: Unpublished Opinions and Government Litigants in the United States Courts of Appeals, 87 MICH. L. REV. 940 (1989); Evan P. Schultz, Gone Hunting: Judge Richard Arnold of the 8th Circuit Has Taken Aim at Unpublished Opinions, but Missed His Mark, LEGAL TimES, Sept. 11, 2000; George M. Weaver, The Precedential Value of Unpublished Judicial Opinions, 39 MERCER L. REV. 477 (1988); and Recent Case, Constitutional Law-Article III Powers-Eighth Circuit Holds that Unpublished Opinions Must Be Accorded Precedential Effect.Anastasoff v. United States, 223 F.3d 898 (8th Cir. 2000), 114 HARV. L. REV. 940 (2001). For a general discussion of the role of precedent, see, for example, Anthony T. Kronman, Precedent and Tradition, 99 YALE L.J. 1029, 1037 (1990); and Frederick Schauer, Precedent, 39 STAN. L. ReV. 571 (1987).

91. In other words, courts should consider whether or not they would be using genealogical comparativism or ahistorical comparativism, with genealogical comparativism being preferred to ahistorical comparativism.

92. Knight v. Florida, 528 U.S. 990, 997 (1999) (Breyer, J., dissenting from denial of certiorari). 
"roughly comparable ... standards," ${ }^{93}$ and he placed particular emphasis on the judicial opinions of countries that are "former Commonwealth nations" " because "those opinions reflect a legal tradition that also underlies our own Eighth Amendment." ${ }^{, 95}$ In other words, the more similar to the United States the legal issue, legal system, legal history, and social situation that the other country faces, the more desirable the use of refined comparativism becomes.

A court should also consider how the comparative constitutional information matters in the domestic context. If a court is crafting broad, abstract legal rules that will basically be litigated and given real content by future American litigation (as opposed to issuing a decision that is much more like legislation), concerns about particularism should be less for two reasons. First of all, a court in that situation is writing for an audience composed of the legal elite. The legal elite is much more concerned than is the regular public with legitimation and therefore with finding that a judicial decision has precedent, whatever shape that precedent may take. ${ }^{96}$ Also, a broad rule that does not have to address the basics of practical implementation (as compared to, for instance, a case finding an Eighth Amendment violation in a particular prison) is less likely to have problems leading to positive outcomes in the American context. Therefore, for these two reasons, the more the court is legislating, and the less it is simply announcing broad appellate rules that will be given actual content by subsequent cases that translate the comparativist insight into the American scene, the more reluctant the court should be to use comparative constitutional law.

A court worried about the practical difficulties of transporting a legal rule or fact into the United States has several options at its disposal to help minimize the problems of particularism. It can, most obviously, simply decline to use comparative constitutional law, even though the case before it is a "hard case" and it feels that using comparative constitutional law could potentially be helpful. A court can also decide to import the comparative constitutional insight, but only in a limited fashion. It can borrow only one particular case from the constitutional law of another country, but decide not to import all relevant precedents from that country, so the seed

\footnotetext{
93. Id.

94. Id.

95. Id.

96. This audience of a judicial decision will not be as affected by the problems of particularism as an audience of the entire public, because, as stated earlier, the legal elite will search for legitimation through precedent and tradition, in this case the precedent and tradition of comparative constitutional law.
} 
from the other country can grow once planted in American ground. A court can also use comparativist insights but make this use tentative-it can apply it to this one case only, thereby not giving its decision any precedential value, or it can apply the comparativist insight with full precedential force, but only after the court has waited a certain period of time to make sure that the constitutional borrowing has been effective.

After deciding that the American sources do not provide a clear answer to an issue the judge faces, and that contextual considerations do not prevent the use of comparative constitutional law, the refined comparativist judge must next consider whether the potential comparative constitutional sources would add anything additional to the case. Another country could have a comparative legal advantage or a comparative sociolegal advantage. In the first instance (comparative legal advantage), another country has simply litigated and answered the question before the American court before any American court (or the particular American court hearing the case) has had an opportunity to do so. Not only does the foreign court have a series of legal principles on the issue, but it may also have documented evidence of how those legal principles work in practice. The country, in short, has faced the legal issue and all that comes with it before the United States has. In Washington v. Glucksberg, ${ }^{97}$ for instance, the Supreme Court could have noted that even before any American court had ruled upon the constitutionality of the laws at issue, courts in Canada ${ }^{98}$ and in India ${ }^{99}$ had ruled on the constitutionality of restrictions on assisted suicide-they have a comparative legal advantage. In the second instance (comparative sociolegal advantage), another country has faced the type of extralegal considerations before the United States has been forced to do so. For example, the Canadian Supreme Court's decision about hate speech in Regina v. Keegstra ${ }^{100}$ dealt with the role of multiculturalism in constitutional law. Demographic change in the United States has created an increasingly multicultural republic, ${ }^{101}$ and Canada had dealt with this extralegal

97. 521 U.S. 702 (1997).

98. Rodriguez v. British Columbia [1993] D.L.R. 342 (Can.) (interpreting the Canadian Charter of Rights and Freedoms not to include a mandatory right to assisted suicide). Chief Justice Rehnquist cited Rodriguez in Glucksberg, 521 U.S. at 718 n.16, but merely as dicta context. The reasoning of Rodriguez played no role in the argument of the Rehnquist opinion.

99. Gian Haur (Smt) v. State of Punjab [1996] 2 L.R.C. 264 (India). The Indian case upheld the criminalization of assisted suicide, after reviewing American, British, and Canadian decisions. Id.

100. [1990] 3 S.C.R. 697 (Can.). For a further discussion of this case, see infra text accompanying notes $347-381$.

101. See, e.g., VAluES AND Public POlicy 9 (Henry J. Aaron et al. eds., 1994). 
consideration and its ramifications for constitutional law before the United States had. ${ }^{102}$

These situations of comparative advantages would be the paradigmatic instances of when a court should consider comparative constitutional law. In those instances, an American court facing a relatively new issue seeks to answer the issue in a way that law finds most desirable: through the lens of experience, in this case comparative constitutional experience. Even without any finding of comparative advantage, however, a court may use comparative constitutional law simply for the originality of the idea of another country ${ }^{103}$ or because comparative constitutional law provides another data point ${ }^{104}$ although these uses of comparative constitutional law are not as defensible as the paradigmatic instances of constitutional borrowing discussed earlier.

\section{B. How a Court Should Use Comparative Constitutional Law: The Process of Trial and Appeal}

How, you might ask, can American judges, most likely trained only in American law and speaking only English, use comparative constitutional law in their judicial opinions? Unfortunately, the little literature on the topic and the past examples of judicial borrowings of comparative constitutional law do not address this issue of improving judicial capacity to use comparative constitutional law. Judges have simply used comparative constitutional law without any consideration of a legal process that might enable them to use comparative constitutional law most effectively.

First of all, structuring a process of refined comparativism would involve the creation of a transnational constitutional law digest, restatements of comparative constitutional law, and more comparative constitutional law casebooks $^{105}$ that would help lead to greater comparative law education in

102. To see if there is any comparative advantage to be gained from using comparative constitutional law, I am proposing that courts actually look into comparative constitutional law, thus creating a situation in which they look at comparative constitutional law before deciding whether or not to use it.

103. This would be a form of ahistorical comparativism-whether or not the lending country has any relationship to American constitutional law, it has an interesting idea. This invokes notions of law as science-if, for example, a scientist in another country made an interesting discovery, we would care very little about the relationship between that scientist's country and our country for the purposes of assessing the validity of the discovery.

104. E.g., Printz v. United States, 521 U.S. 898, 977 (1997) (Breyer, J., dissenting) (stating that comparative constitutional law "may ... cast an empirical light" on American constitutional practice).

105. The recent publication of a comparative constitutional law casebook represents an important step in the right direction. JACKSON \& TUSHNET, supra note 10. The textbook, how- 
American law schools. ${ }^{106}$ In this way, the type of professionalization of law that occurred in other areas of American law in the early and middle part of the last century ${ }^{107}$ could be employed to make comparative constitutional borrowings most effective. ${ }^{108}$ Most importantly, however, the use of comparative constitutional law by judges in their opinions would encourage litigants to make comparative constitutional law part of their briefs and part of their efforts at trial. ${ }^{109}$ The litigants can make use of rules already in place; for instance, Federal Rule of Civil Procedure 44, which states that "[a] party who intends to raise an issue concerning the law of a foreign country should give reasonable notice in his pleadings or other reasonable written notice [to other parties and to the court]."110 In this way, litigants would help the court most effectively use comparative constitutional law by making it part of the regular litigation process. The parties can use a comparative constitutional law expert to help litigants and the court understand the comparative constitutional issues. ${ }^{11}$ This expert may have to give a deposition, be subjected to cross-examination, or actually testify at a summary judgment motion hearing or trial.

The court itself has the power under Federal Rule of Civil Procedure 44, "in determining foreign law," 112 to "consider any relevant material or source." 113 In constitutional cases, since Brown v. Board of Education ${ }^{114}$ and

ever, does not address non-Western constitutional law, which the authors themselves acknowledge. Id. at ix (recognizing that the book would benefit from discussion of "constitutionalism and Islamic cultures, and . . constitutional developments in Latin America, Asia and Africa").

106. For an instructive summary of the history of comparative legal education in American law schools, see Jackson, Ambivalent Resistance, supra note 15, at $592 \mathrm{nn} .43-44$.

107. See, e.g., GEOFFREY C. HAZARD, JR., THE AMERICAN LAW INSTITUTE: WHAT IT IS AND WHAT IT DOES (1994).

108. For example, there could be continuing legal education courses for judges, a section of the American Law Institute devoted to compiling information on comparative constitutional law, and so on.

109. Cf. Abrahmson \& Fischer, supra note 52, at 275 (noting a brief before the Wisconsin Supreme Court that stated the lawyers were unaware if they should cite to foreign law because it is unclear whether foreign law has "precedential value in the United States").

110. FED. R. CiV. P. 44; Grupo Protexa, S.A. v. All Am. Marine Slip, 20 F.3d 1224, 1239 (3d Cir. 1994); Pfizer Inc. v. Elan Pharm. Research Corp., 812 F. Supp. 1352, 1360-61 (D. Del. 1993); 3 Margaret A. Berger et Al., Evidence $\$ 702$ (1996); 9 Charles Alan Wright \& ARTHur R. Miller, Federal PRACTICE AND PROCEDURE § 2444, at 643-48 (2d ed. 1995).

111. If a court does not want to appoint its own expert, and it believes it is being force-fed "junk" foreign law, it can use the principles handed down by the Supreme Court in Daubert v. Merrell Dow Pharmaceuticals, Inc., 509 U.S. 579 (1993). In Daubert, the Court rejected the old "general acceptance" test and held that evidence can be admissible under a new standard that, among other requirements, mandates that evidence must be "relevant . . . [and] reliable." Id. at 589.

112. FED. R. CIV. P. 44; see also John Merryman, Foreign Law as a Problem, 19 STAN. J. INT’L L. 151, 154-55, 172-73 (1983).

113. FED. R. CIV. P. 44.

114. 347 U.S. 483 (1954). 
the negative reaction ${ }^{115}$ to footnote eleven's use of social science ${ }^{116}$ (even though the footnote played such a small role in the Court's decision ${ }^{117}$ ), courts have been unwilling to use resources at their disposal to increase their fact-finding powers. ${ }^{118}$ In the case of foreign law, however, frequently the lawyers "will do an inadequate job of researching and presenting foreign law or will attempt to prove it in such a partisan fashion that the court is obliged to go beyond their offerings." ${ }^{119}$ To help them make their own decisions, courts that consider using comparative constitutional law (or have already decided to use it) can rely on some of the other federal rules. Federal Rule of Evidence 706 permits a court on its own motion to appoint an expert witness. ${ }^{120}$ An expert witness can conduct his or her own research and then advise the parties of his or her findings. Any party may take a deposition of the expert and the expert may be called to testify by the court or by a party. A court can also use Federal Rule of Civil Procedure 53 to appoint a special master, who would help the court with a foreign law issue. $^{121}$ The special master makes a final report to the judge. ${ }^{122}$ If the court is concerned about contextual differences and how a comparative rule would work in the American context, the court may appoint someone trained to study differing institutional contexts who may look at sources beyond written constitutional, statutory, and decisional law to determine how the law has actually worked in another country. ${ }^{123}$

115. Ernest van den Haag, Social Science Testimony in the Desegregation Cases-A Reply to Professor Kenneth Clark, 6 VILL. L. ReV. 69 (1960). See generally MiCHAEL J. SAKS \& CHARLES H. BARon, The Use/Nonuse/Misuse of APPlied SOCIAL RESEARCH IN THE COURTS (1980) (providing an overview of the way social science research has been used by the courts and the ways in which this use has been criticized); Kenneth L. Karst, Legislative Facts in Constitutional Litigation, 1960 SUP. CT. REV. 75 (examining the role of "facts" in the creation of constitutional law). Some scholars have defended Brown's use of social science. E.g., PAUL L. ROSEN, THE SuPREME COURT AND SOCIAL SCIENCE 134-72 (1972) (defending Brown's use of social science as a continuation of the sociological jurisprudence of Louis Brandeis, Benjamin Cardozo, and Roscoe Pound).

116. Brown, 347 U.S. at 494 n.11.

117. See Edmond Cahn, Jurisprudence, 30 N.Y.U. L. REV. 150, 157-67 (1955).

118. See Missouri v. Jenkins, 515 U.S. 70, 119-20 \& n.2 (1995) (Thomas, J., concurring) (criticizing Brown and other cases for their use of social science).

119. Twohy v. First Nat'l Bank of Chi., 758 F.2d 1185, 1193 (7th Cir. 1985).

120. FED. R. EVID. 706.

121. FED. R. CIV. P. 53.

122. A number of reported cases mention the use of a court-appointed special master to resolve foreign law issues. E.g., Roberts v. Heim, 130 F.R.D. 430 (N.D. Cal. 1990); Corporacion Salvadorena de Calzado, S.A. v. Injection Footwear Corp., 533 F. Supp. 290 (S.D. Fla. 1982). But see Washington v. Glucksberg, 521 U.S. 702, 787 (1997) (Souter, J., concurring) (questioning "whether an independent front-line investigation into the facts of a foreign country's legal administration can be soundly undertaken through American courtroom litigation").

123. The court can rely on a list of experts on constitutional law in different countries maintained by organizations such as the American Foreign Law Association and the American 
At the Supreme Court level, it is unclear whether the Court itself can use all of these powers, ${ }^{124}$ but it certainly can rely on the lower trial and appellate courts that have made use of these powers. Although the Supreme Court could reach out and use comparative constitutional law even when not briefed, ${ }^{125}$ it should encourage counsel to brief comparative constitutional law arguments just as it should encourage lower courts to make use of their powers to look at comparative constitutional law. ${ }^{126}$ This way, the Court is overcoming its relative institutional isolation and trying to do the best it can with comparative constitutional law. Indeed, even if counsel does not address comparative constitutional law, the Court itself may ask counsel to brief the comparative issues just as it would ask them to brief specific legal issues. ${ }^{127}$ Still, the unique limitations the Court itself faces may encourage the Court to allow for greater comparative experimentalism in the lower courts because of their greater ability to deal with comparative constitutional issues.

Academy of Foreign Law. A court can use an expert in the stage when it decides whether or not to use comparative constitutional law at all, even before deciding how it actually may use comparative constitutional law.

124. The current practice of the Court allows for special masters for cases within the Court's original jurisdiction, as in New Jersey v. New York, 513 U.S. 924 (1994), but does not do so for cases it hears on appeal, even when the lower court has not addressed the question the Court would consider consulting a special master to help them resolve. The powers of the Court to appoint a special master in cases that fall outside of its original jurisdiction are not entirely clear. In cases in which the Court exercises its original jurisdiction, 'the scope of the Masters' authority is not always clear [because] the Court's rules make no provision respecting the proceedings before a Master." Robert L. Stern et Al., Supreme Court Practice 487 (7th ed. 1983). Sup. CT. R. 17.2 does allow for the application of the Federal Rules of Civil Procedure and the Federal Rules of Evidence in cases in which the Court exercises its original jurisdiction. Id. at 488 n.38. It is not entirely clear if this means that in cases where the Court exercises appellate jurisdiction those rules do not apply - and whether or not because those rules do provide for the appointment of special masters, stating those rules do not apply necessarily means that the Court is without authority to appoint a special master according to regulations it may make outside of the federal rules.

125. This has been the usual practice-the cases over its history in which the Court cites comparative constitutional law only rarely involve a mention of comparative constitutional law in any of the briefs, oral arguments, or lower court opinions that the Court reviews. As Martin S. Flaherty pointed out to me, however, the Lawyers' Committee for Human Rights was going to initiate a project whereby it would file amicus briefs that made frequent reference to comparative constitutional law, but this project never materialized.

126. This decentralized approach to comparative constitutional law has obvious advantages because of the institutional limitations facing the Court. Lower trial courts, and even lower appellate courts, have a greater ability to inquire into the idiosyncrasies of comparative constitutional law and therefore can make a better determination of the appropriateness of borrowing and how comparative constitutional law might best be used.

127. E.g., Feltner v. Columbia Pictures Tel., Inc., 521 U.S. 1151 (1997); Bogan v. ScottHarris, 520 U.S. 1263 (1997). 
TABLE 1: SUMMARY OF REFINED COMPARATIVISM

\begin{tabular}{|l|ll|}
\hline$>\begin{array}{l}\text { When to use refined } \\
\text { comparativism }\end{array}$ & $>$ & $\begin{array}{l}\text { Hard case } \\
\text { No contextual problems (relevant factors include com- } \\
\text { parative similarities, domestic audience) }\end{array}$ \\
& $>\begin{array}{l}\text { Comparative legal advantage/comparative sociolegal } \\
\text { advantage or data points }\end{array}$ \\
\hline$>\begin{array}{l}\text { Resources for a } \\
\text { refined comparativ- } \\
\text { ist judge }\end{array}$ & $>$ & $\begin{array}{l}\text { Litigants argue comparative constitutional law } \\
\text { Litigants use expert witness } \\
\end{array}$ \\
\hline
\end{tabular}

\section{The VIRTUES OF REFINED COMPARATIVISM}

The refined comparativist vision I sketched out earlier has many advantages for American constitutional law and for American constitutional scholarship. First of all, it has several practical advantages that will lead to "better law." Simply put, it will force courts to look at a broader range of ideas and possibilities, and will lead to a richer judicial dialogue. Courts will have a wider range of relevant precedent and legal options to look at, and will be able to choose constitutional principles and constitutional facts that will help them decide cases before them. At a normative level, refined comparativism can have a positive impact in broadening the cultural horizon of constitutional law-it can help constitutional law come to grips with the evolution of a multicultural society. This can be accomplished through recognition of the relevance of foreign cultures to our constitutional law, and by allowing for greater value clarification.

\section{A. Pragmatic Virtues of Refined Comparativism}

The first set of advantages of refined comparativism fall under the rubric of "better solution" comparative law: ${ }^{128}$ Using the insights of comparative constitutional law will lead to better solutions to questions posed by

128. 1 KONRAD ZWEIGERT \& HEIN KÖTZ, INTRODUCTION TO COMPARATIVE LAW 15 (Tony Weir trans., 2d ed. 1987) (stating that "[comparative law] offers ... the opportunity of finding the 'better solution' for ... [t] his time and place"); Abrahmson \& Fischer, supra note 52, at 287 ("In fact, foreign opinions could function like superstar amicus briefs, offering otherwise unavailable viewpoints, delivered from unique perspectives, by some of the world's leading legal minds."); Wolfgang Däubler, Comparison of Labor Law in Socialist and Capitalist Systems, 4 COMP. LAB. L.J. 79, 85-86 (1981) (noting the innovative new solutions to labor problems in Socialist countries); Friedrich K. Juenger, American Jurisdiction: A Story of Comparative Neglect, 65 U. COLO. L. REV. 1, 1 (1993) (arguing that comparative law "provides a storehouse of solutions"). See generally EDWARD JENKS, THE NEW JURISPRUDENCE (1933) (advocating the comparative method as a helpful way of finding new legal ideas). 
American constitutional law. ${ }^{129}$ Consider two situations under refined comparativism when a court should contemplate using comparative constitutional law. The first situation is when another country (or group of countries) has evolutionary/comparative advantages-this country or these countries have already dealt with the issues that the American court now faces. Remember that these legal policy evolutionary advantages can be either legal (experience dealing with the creation of a particular legal rule or experience with how a particular legal rule works) or sociolegal (they have had greater experience dealing with the extralegal elements). In these instances, American courts facing an issue that they have relatively little experience with would have their own "laboratories" 130 from which to glean insights about the proper course of action. American courts would be taking advantage of the "rise of world constitutionalism"131 and would benefit from the different rules regarding standing in other countries that may allow them to decide issues in courts faster than American courts do. ${ }^{132}$ American courts would reap all of the benefits of legal and practical experience without having to compromise their traditional rules of standing, ripeness, and the like. The American court using comparative constitutional law can use Vincent Blasi's idea of the pathological perspective ${ }^{133}$ to avoid the harmful results of rules that resulted in other countries, or can adjust the rules from other countries based on what worked best there without having to endure the difficulties of the trial run that the foreign country did.

The second situation in which refined comparativism would be particularly appropriate is when the lending country (or group of countries) being examined has no evolutionary advantages-its legal and social development has not addressed an issue earlier than the United States has-but that country provides a helpful set of data points. In crafting a workable judicial principle, for example, another country simply has an interesting idea that a

129. The little literature on the economics of comparative law has noted that it is economically efficient to borrow. E.g., Ugo Mattei, Efficiency in Legal Transplants: An Essay in Comparative Law and Economics, 14 INT'L REV. L. \& ECON. 3 (1994).

130. Cf. New State Ice Co. v. Liebmann, 285 U.S. 262, 311 (1932) (Brandeis, J., dissenting) (arguing that states "may... serve as a laboratory; and try novel social and economic experiments"). For arguments in favor of the "laboratory" model of federalism, see DAVID L. Shapiro, FederAlism: A DiAlogue 85-88 (1995); Larry Kramer, Understanding Federalism, 47 VAND. L. REV. 1485, 1499 (1994); and Michael McConnell, Federalism: Evaluating the Founders' Design, 54 U. CHI. L. REV. 1484, 1498-500 (1987). For criticisms of the laboratory model, see Susan Rose-Ackerman, Risk Taking and Reelection: Does Federalism Promote Innovation?, 9 J. LEGAL STUD. 593 (1980). For a rejoinder to Susan Rose-Ackerman's arguments, see Barry Friedman, Valuing Federalism, 82 MiNN. L. REV. 317, 397-400 (1997).

131. Ackerman, supra note 3, at 772.

132. See, e.g., Martin Shapiro, COURTS: A Comparative And Political ANAlysis (1981); STONE, supra note 9.

133. Supra note 59. 
court could borrow, ${ }^{134}$ just as a court may borrow an interesting idea from legal scholarship. Or, as Justice Breyer used comparative constitutional law in Printz v. United States, ${ }^{135}$ these comparative inquiries may help cast an "empirical light" ${ }^{136}$ on how the law works. Considering institutional limitations facing the judiciary, these extra data points may be especially helpful. For one thing, globalization plus advanced social science means that the data from law in action abroad might make comparative constitutional law a helpful source of constitutional fact. In crafting rules of law or workable principles, the more possibilities a judge can consider, the more likely he or she is to craft a principle that does justice to the American sources. In this way, comparative constitutional law is a means of overcoming domestic constitutional uncertainty. The diversity of the American constitutional experience may call out for a principle that cannot be found anywhere in the American sources, but that can be created from comparative sources.

In a system of refined comparativism, if a court uses comparative constitutional law due either to comparative evolutionary advantages or simply to locate more data points, there would be a number of benefits that would follow. First, refined comparativism would force courts to open their eyes to the true assumptions behind American constitutional law, ${ }^{137}$ and would dispel any sense of false necessity. ${ }^{138}$ As Clifford Geertz has written, sometimes it is helpful to look to other cultures simply to help us understand that elements of our own culture, which seem so natural and obvious as to be unself-conscious, are indeed not natural or inevitable components of human existence. ${ }^{139}$ Looking to other countries may make a court understand the unstated assumptions and arguments behind its opinion, thereby increasing

134. See, e.g., United States v. Then, 56 F.3d 464, 468 (2d Cir. 1995) (Calabresi, J., concurring) ("American courts might...take note of what the Constitutional Courts of some cognate countries have done in like situations.").

135. 521 U.S. 898 (1997).

136. Id. at 977 (Breyer, J., dissenting).

137. See Mary Ann Glendon, Abortion And Divorce in Western LaW 8-9 (1987); Ewald, supra note 4; Frankenberg, supra note 4; cf. Mitchel de S.-O.-l'E. Lasser, Comparative Law and Comparative Literature: A Project in Progress, 1997 UTAH L. REV. 471, 474-77.

138. The term "constitution" gives one a sense that the present system of arrangements was somehow inevitable-the exposure to other legal systems will teach one otherwise.

139. ClifFORD GeERTZ, LOCAL KNOWLEDGE 57 (1983). Through this process we would not only learn the value of other constitutional systems, but we would also learn the value (and problems) of our own constitutional system. See J.B. White, JUSTICE AS TRANSLATION 257 (1990). Alasdair MacIntyre notes that individuals encountering an "alien" tradition may discover that it provides a perspective from which "the limitations, incoherences, and poverty of resources of their own beliefs can be identified, characterized, and explained in a way not possible from within their own tradition." ALASDAIR MACINTYRE, WHOSE JUSTICE? WHICH RATIONALITY? 387-88 (1988). 
judicial candor, ${ }^{140}$ and may encourage a frank discussion of all relevant legal arguments:

Instead of pretending to the posture of a neutral, objective, and disinterested observer, the comparatist has to regard herself as being involved: involved in an ongoing, particular social practice constituted and pervaded by law; involved in a given legal tradition (a peculiar story of law); and involved in a specific mode of thinking and talking about law. ${ }^{141}$

Also, under positive comparativism the court using comparative constitutional law is simply able to make itself a more widely read constitutional court, one that is aware of a broader range of possible effective solutions. Negative comparativism may provide a useful sort of constitutional reasoning to help a court examine the bare minimum number of items it can take to be true. Consider this a variation of Jed Rubenfeld's idea of locating paradigm cases ${ }^{142}$ or Cass Sunstein's notion of reasoning by analogy from paradigm cases. ${ }^{143}$ A court can see what it clearly believes our constitutional law is not by locating the paradigmatic example of what it considers our constitutional regime to reject, and thus help it understand what our Constitution is by reasoning by analogy from those negative paradigm cases. ${ }^{144}$ At base, better solution comparative law virtues of refined comparativism help us realize that law, in looking for better solutions, prefers those that have been tested and tried; law values experience over speculation. ${ }^{145}$

140. This is of course a desirable outcome only if judicial candor is a good thing. Only some scholarship directly focuses on judicial candor-see, for example, GUIDO CALABRESI, A COMmon LAw For the Age of StatuTes 172-77 (1982); Scott Altman, A Prudential Theory of Judicial Candor, 73 TEX. L. REV 1307 (1995); Susan Estrich, The Justice of Candor, 74 TEX. L. REV. 1227 (1996); and David Shapiro, In Defense of Judicial Candor, 100 HARV. L. REV. 731 (1987).

141. Frankenberg, supra note 4, at 443.

142. E.g., Jed Rubenfeld, The Right of Privacy, 102 HARV. L. REV. 737, 804 (1989).

143. E.g., Cass R. Sunstein, On Analogical Reasoning, 106 HARV. L. REV. 741 (1993); cf.

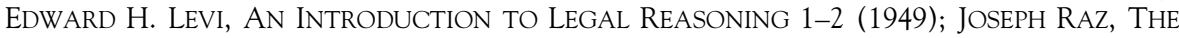
AUTHORITY OF LAW 201-06 (1979). To use another of Cass Sunstein's ideas, using negative paradigmatic comparativism might be one way of deciding hard cases through "judicial minimalism." Cass R. Sunstein, One CASE AT A Time: Judicial Minimalism ON THE Supreme COURT (1999); see also Cass R. Sunstein, The Supreme Court, 1995 Term-Foreword: Leaving Things Undecided, 110 HARV. L. REV. 4 (1996). Those attracted to the idea of judicial minimalism should be similarly attracted to the idea of negative paradigmatic comparativism-deciding a case simply by deciding what the U.S. Constitution is not.

144. I have listed many examples of negative comparativism throughout this Article; see, for example, supra note 59.

145. The law would seem to prefer a decision that rests on an established system of law rather than on an innovative judicial decision, because an established system of law "expresses the experience of many... [rather than] employ[ing] a personal yardstick of [its] own." EUGEN 
This vision of refined comparativism also fits with other important trends in contemporary American constitutional jurisprudence. First, the trend towards balancing and cost-benefit analysis in constitutional adjudication calls for a fuller accounting of all relevant information in a constitutional case. Here, the type of comparative constitutional law analysis used to find certain constitutional facts becomes helpful. The past experience of other countries can help an American court determine if the legislative means used in a piece of legislation before the court really helps achieve the desired end. ${ }^{146}$ The past experience of other countries can help a court determine how successful a certain program will be. In the case of judicial balancing, as will be discussed in Part VII, other countries may have some experience with the benefits of certain programs and will have been able to see the relative impact a governmental activity has on both sides whose interests are being balanced. The ambiguity in constitutional adjudication introduced by the move from formalism to cost-benefit functionalism would be partially remedied by the fuller accounting of costs and benefits that results from using comparative data.

Refined comparativism can be one way of adjusting to certain sociolegal changes that should alter our understanding of the proper role of the judge in constitutional cases. Constitutional scholarship focusing on the judiciary and on constitutional interpretation has failed to sufficiently analyze important extralegal changes such as multiculturalism and technological advancement. Now that social change occurs rapidly through technological progression and the like, constitutional gradualism will be an increasingly ineffective means of constitutional evolution. Gradual constitutional change does not allow judges to benefit from the lessons of experience. In the American constitutional system, federal judges have an even harder time learning from experience because of the isolation created by Article III. ${ }^{147}$ The primary confidants and peers of contemporary federal judges, law clerks, have very little experience and are drawn from the same law school

LANGEN, TRANSNATIONAL COMMERCIAL LAW 216 (Bernard Noble trans., 1973) (citing GERHARD KAGEL, LEO RAAPE UND DAS INTERNATIONALE PRIVATRECHT DER GEGENWART, 18 RABELSZ 7 (1966)). This argument seems particularly compelling in the contemporary sociolegal context of constitutional law. Societal diversity will make it hard for a judge to have a true understanding of the consequences of his or her decisions. In addition, the courts of foreign countries have developed more mature systems of adjudication than in the past, and so their solutions deserve greater respect than they did in the past.

146. E.g., Washington v. Glucksberg, 521 U.S. 702, 786 (1997) (Souter, J., concurring) (looking to Dutch constitutional practice to judge the means-end fit of American state laws).

147. This is of course not a new argument. See, e.g., Erwin N. Griswold, The Supreme Court, 1959 Term-Foreword: Of Time and Attitudes-Professor Hart and Judge Arnold, 74 HARV. L. REV. 81, 81 (1960) ("[T]he Supreme Court is inevitably an isolated and remote body."). 
culture of constitutional gradualism as judges. ${ }^{148}$ In the contemporary age, when change occurs so rapidly, and in such a diverse country, we should worry about these problems the judiciary faces in attempting to learn from experience and should encourage the judiciary to focus more on workable solutions drawn from the lessons of experience ${ }^{149}$ and less about the meaning of authoritative texts. ${ }^{150}$

One way of encouraging judges to learn from experience and to look for practical solutions is to encourage a kind of legal experimentalism. This means deference to and greater study of American policymaking institutions, but also means that judges may learn about the real-world consequences of judicial action from the experience of other countries. ${ }^{151}$ This type of "transjudicial communication" ${ }^{152}$ with other constitutional adjudicative bodies around the world may also help spread American jurisprudence. ${ }^{153}$ Other constitutional court judges have sometimes noted with anger the relative unwillingness of American constitutional law to learn from experience abroad, ${ }^{154}$ and as a kind of crude reciprocal revenge have refused to consider American constitutional law. If American constitutionalists are convinced that they have the right answer, one way to spread this

148. As long as law students apply for clerkships in the fall of the second year, after completing the common law courses of the first year of legal education, this will inevitably be the case: The better the student performs in their first year common law courses, the stronger a candidate they are for a clerkship, and stronger candidates usually receive federal clerkships.

149. See Michael C. Dorf, The Supreme Court, 1997 Term-Foreword: The Limits of Socratic Deliberation, 112 HARV. L. REV. 4 (1998) (arguing for "provisional adjudication" as a way of overcoming institutional limitations facing courts and enabling courts to participate in the effective implementation of a constitutional regime); Richard H. Fallon, Jr., The Supreme Court, 1996 Term-Foreword: Implementing the Constitution, 111 HARV. L. REV. 54 (1997) (arguing that part of the mission of the Supreme Court is to not only find the meaning of the Constitution but also to implement the Constitution successfully).

150. Cf. Michael C. Dorf, Truth, Justice, and the American Constitution, 97 COLUM. L. REV. 133, 146-52 (1997) (criticizing Ronald Dworkin's argument that hard cases have correct answers because of the limitations of the judiciary in finding such correct answers even if they did exist).

151. This is partly the reason for Judge Posner's argument that the Court should make greater use of social science research. RiCHARD A. POSNER, THE PROBLEMATICS OF MORAL AND LEGAL THEORY (1999); Posner, supra note 60, at 11-12.

152. Anne-Marie Slaughter, A Typology of Transjudicial Communication, 29 U. RICH. L. REV. 99 (1994).

153. E.g., Clare L'Heureux-Dube, The Importance of Dialogue: Globalization and the International Impact of the Rehnquist Court, 34 TULSA L.J. 15, 20 (1998) (noting that the "worldwide influence of the U.S. Supreme Court" has been greater in previous years because previous Supreme Courts have been more willing to cite to and use comparative constitutional law). Many in the constitutional law establishment have changed their mind about the desirability of spreading American constitutional ideas to other countries around the world. See Howard \& Fontana, supra note 18 , at $17-27$.

154. L'Heureux-Dube, supra note 153, at 21 (arguing that it is "disrespectful" to other courts around the world for American courts to entirely ignore them). 
constitutional gospel is through a respectful analysis of the decisions of other constitutional courts around the world.

\section{B. Normative Virtues of Refined Comparativism}

Refined comparativism will also have several normative benefits for American constitutional law. To the extent that American constitutional scholarship has used comparative constitutional law, it has typically used the type of thin genealogical comparativism present in cases like Loving $v$. United States ${ }^{155}$-looking to English history because that is one of the sources of or predecessors to American law. Refined comparativism would encourage American constitutional law to develop a richer sense of genealogical comparativism, recognizing the full panoply of American diversity that leads to a broader constitutional identity than contemporary American constitutional law recognizes. The vision of comparative constitutional law that only uses the thin genealogical comparativism behind Loving misses relevant sources of American constitutional identity. What would this thick genealogical comparativism include?

First of all, this thick genealogical comparativism would recognize that part of who we are-what constitutes us - is of course where our present legal system came from. This is the thin genealogical version that looks at English history as well as Greek, Roman, and other legal systems that the Founders borrowed from in creating the Constitution. There are also genealogical linkages with those countries that share a common heritage, cultural and legal, with the United States. Justice Breyer's opinion in Knight v. Florida ${ }^{156}$ uses this version of genealogical comparativism, looking to "former Commonwealth nations" ${ }^{\text {"157 }}$ because their "opinions reflect a legal tradition that also underlies our own [constitutional system]."158 This "common heritage" version of thick genealogical comparativism has been used in American constitutional law that has looked at state constitutional practice as a relevant source in making American federal constitutional law-states come from the same basic legal tradition as does the federal government, and therefore their constitutional ideas are relevant sources of constitutional law.

Recently, we can add to this "common heritage" branch of thick genealogical comparativism an offspring version of genealogical comparativism. While countries have long borrowed from American constitutional law and

155. 517 U.S. 748 (1996).

156. 528 U.S. 990 (1999).

157. Id. at 997 (Breyer, J., dissenting from denial of certiorari).

158. Id. 
sought the advice of American constitutionalists, ${ }^{159}$ it is not until the last fifty years or so that countries have relatively successfully borrowed from American constitutional law. As Judge Calabresi notes in United States $v$. Then: ${ }^{160}$

At one time, America had a virtual monopoly on constitutional judicial review.... [Drawing] origin and inspiration from American constitutional theory and practice ... [t] hese [newer democracies] are our "constitutional offspring" and how they have dealt with problems analogous to ours can be very useful to us when we face difficult constitutional issues. Wise parents do not hesitate to learn from their children. ${ }^{161}$

We can add to the common heritage and offspring versions of thick genealogical comparativism a notion of constitutive constitutional identity that should be part of a thick genealogical comparativism. This constitutive version of constitutional identity supporting a thick genealogical comparativism essentially states that "the United States is very similar to the world." First, this constitutive constitutional identity can be one way of taking account of the impact multiculturalism should have on American constitutional law. Now that Americans come from all over the place, and have become part of the American constitutional polity, we must take account of them and their traditions and habits, because the traditions and habits of American citizens are relevant in constructing American constitutional law. Now that Americans come from countries all over the world, to fully understand who they are and their relevance to our constitutional praxis, we must study the constitutional law of their countries. The second element of this globalized version of constitutive constitutional identity notes that we are all global citizens now, sharing at some level the same basic mission and goals to protect certain fundamental rights and beliefs. Although many Americans from other countries come to our constitutional republic to flee their own legal tradition, there will be sublegal and cultural elements of their former country's legal and social systems that must be incorporated into our own constitutional system. This makes it all the more important that refined comparativism does not result in a Eurocentric refined comparativism $^{162}$-although a comparativist judge may naturally look to Germany and France, it is all the more important now that the judge look to the countries from which the most recent wave of American citizens come from originally.

159. Howard \& Fontana, supra note 18 , at 7-23.

160. 56 F.3d 464 (2d Cir. 1995).

161. Id. at 469 (Calabresi, J., concurring).

162. Infra text accompanying notes 411-415. 
Refined comparativism can also help with domestic value clarification. This becomes especially true when one considers the notion of negative comparativism that I earlier introduced. It may be helpful to locate the American "public philosophy"163 or "overlapping consensus"164 in a multicultural age if we can reason from certain paradigmatic instances of what we are not. Take, for example, the case of Shaughnessy v. United States ex rel. Mezei. ${ }^{165}$ In that case, the Court ruled on the constitutionality of the continued exclusion of an alien from the United States without a hearing, although the alien had no country to return to while he was excluded. The dissent noted the difficulty in finding a shared national value system or practice,${ }^{166}$ so instead used the system of negative paradigmatic comparativismreasoning by looking at the paradigmatic instance of what our constitutional system is not. Justice Robert Jackson's dissent objected to executive detention of aliens without a hearing as bearing "unmistakable overtones of the

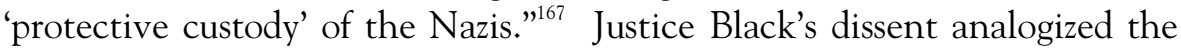
detention practices to Soviet and Nazi practices. ${ }^{168}$

\section{A History of Refined COMPARATIVISM}

Does this method of using comparative constitutional law in American judicial decisions have historical support? Perhaps surprisingly, there is a long history of American judges using comparative constitutional law in their judicial opinions. The Court has not always used comparative constitutional law when it could have, but rather has a long history of making occasional references to it (this Article argues that although there are past examples of the Court using comparative constitutional law, the Court should use it more often). Thus, Part IV serves to show not that the Court has quite often looked to comparative constitutional law, but rather that there is some

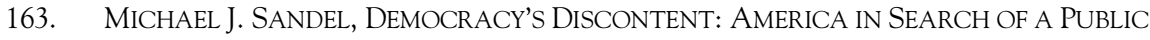
PHILOSOPHY (1996).

164. JOHN RAWLs, POlitical LibERALiSM (1993); John Rawls, The Basic Liberties and Their Priority, in 3 THe TANNer Lectures on Human VAlues 1 (Sterling M. McMurrin ed., 1982); John Rawls, The Basic Structure as Subject, 14 AM. PHIL. Q. 159 (1977); John Rawls, The Idea of an Overlapping Consensus, 7 OXFORD J. LEGAL STUD. 1 (1987); John Rawls, Justice as Fairness: Political Not Metaphysical, 14 PHIL. \& PUB. AfF. 223 (1985); John Rawls, Kantian Constructivism in Moral Theory: The Dewey Lectures: Rational and Full Autonomy, 77 J. PHIL. 515 (1980); John Rawls, The Priority of Right and Ideas of the Good, 17 PHIL. \& PUB. AFF. 251 (1988).

165. 345 U.S. 206 (1953).

166. Id. at 218 (Jackson, J., dissenting) (finding it hard to locate an agreed upon moral consensus on the issue before the Court "in this country").

167. Id. at 226.

168. Id. at 217-18 (Black, J., dissenting); see also id. at 224 (Jackson, J., dissenting) (using negative paradigmatic comparativism by referring to Soviet practices). 
precedent for refined comparativism. However, considering that liberal democratic constitutional regimes were not common until fairly recently, ${ }^{169}$ this comparativist judicial impulse is all the more surprising. A study of the use of comparative constitutional law shows that the Court, and indeed the Founders before it, used many of the techniques of refined comparativismfinding American sources to be unclear and then using comparative sources that come from similar contexts to help reach a decision.

The Founding itself provides support for refined comparativism. Justice Scalia argued in Printz v. United States ${ }^{170}$ that the Founders' “interpretive intention" was for comparative materials to be used only in the drafting of the Constitution but not in its interpretation. ${ }^{171}$ In fact, several of the leading documents from the Founding and the general intellectual context of the Founding seem to suggest otherwise. The comparativist impulses of the Founding have carried over into subsequent case law at the Supreme Court level.

\section{A. Founding}

As Justice Scalia argued in Printz, "comparative analysis ... was ... relevant to the task of writing"172 the U.S. Constitution. But was the Founders' original "interpretive intention" "173 that comparative materials would only be used in drafting the Constitution and not in its interpretation, as Justice Scalia also claimed in Printz? In fact, the evidence from the Founding demonstrates quite the opposite. The Founders wanted comparativism to be as much a part of constitutional interpretation as it was of constitutional creation. Comparative insights had undeniable

169. E.g., CAPPELLETTI \& COHEN, supra note 10, at 13-16 (arguing that comparative constitutional law only became viable after World War II).

170. $\quad 521$ U.S. 898 (1997).

171. Id. at 921 n.11 ("Comparative analysis [is] inappropriate to the task of interpreting a constitution, though it was of course quite relevant to the task of writing one.").

172. Id.

173. My goal here is not to extensively involve myself in and say something new about the interesting debate about the "original understanding of original intent," H. Jefferson Powell, The Original Understanding of Original Intent, 98 HARV. L. REV. 885 (1985), but rather to use the available information about that original understanding to see whether it allowed for the use of comparative constitutional materials. For comments on H. Jefferson Powell's article, see, for example, Hans W. Baade, "Original Intent" in Historical Perspective: Some Critical Glosses, 69 TEX. L. REV. 1001 (1991); Robert N. Clinton, Original Understanding, Legal Realism, and the Interpretation of "This Constitution," 72 IOWA L. REV. 1177 (1987); Paul Finkelman, The Constitution and the Intentions of the Framers: The Limits of Historical Analysis, 50 U. PITT. L. REV. 349 (1989); Charles A. Lofgren, The Original Understanding of Original Intent?, 5 CONST. COMMENT. 77 (1988); and William J. Michael, The Original Understanding of Original Intent: A Textual Analysis, 26 OHIO N.U. L. REV. 201 (2000). 
influence on the Founders, and nowhere did they indicate that these insights would be restricted just to 1787 . Rather, their acceptance of certain universalist intellectual ideas and their interest in the experiential lessons of political science seem to indicate that they wanted comparative materials to always be used.

The influence of comparative law on the Founding has received a good deal of scholarly attention. ${ }^{174}$ This discussion will not rehearse old arguments about the influence of comparative constitutional law on the Founders, but will simply discuss the consensus of the literature in terms of its relationship to refined comparativism. It is fair to say that the major works on the comparativist influence on the Founding ${ }^{175}$ agree that not blackletter comparative law, but rather comparative constitutional theory, influenced the drafting of the Constitution, especially the radical Whig interpretation of the British Constitution, an interpretation coming from the works of Harrington, Milton, and Sidney, and extending to such eighteenth century thinkers as John Trenchard, Thomas Gordon, Richard Price, Benjamin Hoadley, and James Burgh. In general, the literature agrees that there were three main comparativist influences on the Founders: (1) political theorists of the Enlightenment, including Locke, Montesquieu, Voltaire, Rousseau, Beccaria, Grotius, and Vattel; (2) philosophical and literary works of classical antiquity, including the history of the Roman Republic as depicted by Cicero, Plutarch, Sallust, and Tacitus (or as it appeared in such modern works as Addison's Cato); and (3) common law lawyers, including Coke, Bacon, Hale, and Blackstone. While it is true that this was much of the "law" out there at the time, there was also a very well-developed American jurisprudence and series of cases. These were available not through traditional case reporters but through other sources of legal

174. E.g., David A.J. Richards, Revolution and Constitutionalism in America, 14 CARDOZO L. REV. 577, 584-86 (1993) (discussing the Founders' use of the comparative political science of Machiavelli, Harrington, Montesquieu, Hume, Smith, Ferguson, and Millar).

175. The classic account is GORDON S. WOOD, THE CREATION OF THE AMERICAN REPUBLIC, 1776-1787 (1969). I have also looked at the following works: 1 BRUCE ACKERMAN, We the PeOple: Foundations (1991); AMERICAN POliticAl Writing During the Founding ERA (Charles Hyneman \& Donald Lutz eds., 1983); BERnARd BAilyn, THE IDEOLOGICAL ORIGINS OF THE AMERICAN REVOLUTION (1967) [hereinafter BAILYN, ORIGINS]; BERnARD BAILYN, THE ORIGINS OF AMERICAN POlITICS (1968); CARL BECKER, THE DEClARATION OF INDEPENDENCE (1922); LAW IN THE AMERICAN REVOlUTION AND THE REVOlution IN THE LAW (Hendrik Hartog ed., 1981); PETER ONUF, THE ORIGINS OF THE FEDERAL REPUBLIC: JURISDICTIONAL CONTROVERSIES IN THE UNITED STATES, 1775-1787 (1983); JOHN PHILlip Reid, CONSTITUTIONAl History OF THE AMERICAN REVOlution (1986); Clinton Rossiter, 1787: THE GRAND CONVENTION (1966); MORTON White, Philosophy, THE FEDERALIST, AND THE CONSTITUTION (1987); GARRY WiLls, INVENTING AMERICA: JEFFERSON'S DECLARATION OF INDEPENDENCE (1978); and GORDON S. WOOD, THE RADICALISM OF THE AMERICAN REVOLUTION (1991). 
reporting. Still, instead of using that body of knowledge, the fact that the Founders looked to comparative knowledge-and more specifically to comparative sources beyond simply the traditional English sources (Blackstone, Coke)—is quite telling.

Although these comparative sources of influence hardly form a coherent picture of constitutional thought, several generalizations about comparativist influence can be made. First, natural law and its revelation of universalist truths influenced the Founders:

[F]or American judges in the late eighteenth century, the sources of fundamental law were as open-ended as they were in English opposition theory. The colonists inherited a tradition that provided not only a justification for judicial review but also guidelines for its exercise. As Bolingbroke proposed in theory and the new American states translated into action, judges were to look to natural law and the inherent rights of man, as well as to the written constitution, in determining the validity of a statute. Where the written constitution affirmatively addressed a problem-most often in governmental structure cases ... but even in cases ... where the constitution provided clear protection of individual rights-it was dispositive, but in other cases, judges looked outside the written constitution. ${ }^{176}$

This interest in natural law appears in many places after the enactment of the Constitution. ${ }^{177}$

Comparativist inquiry under natural law helped reveal these universalist truths by looking to the thoughts of others. These "inherent rights of man" could be revealed through comparativist inquiry either at the time of constitutional drafting or of constitutional interpretation by looking to the revealed truths of natural law and reason as others had discovered them.

176. Suzanna Sherry, The Founders' Unwritten Constitution, 54 U. CHI. L. REV. 1127, 114546 (1987). My goal here is not to involve myself in the extensive debate about the role of natural law at the Founding. There already exists an extensive and through literature on this topic. E.g., Philip A. Hamburger, Natural Rights, Natural Law, and American Constitutions, 102 YALE L.J. 907 (1993); Sherry, supra. My only point is that whatever one may think about the exact role of natural law in the Founding, it is fairly clear that it at least played some role.

177. Several of the earliest and most important cases debating the power of the courts to review statutes (involving many important figures of the early Republic) invoked natural law claims. Alexander Hamilton's argument in Rutgers v. Waddington concerned a claim that a New York statute violated the law of nations. Brief No. 6 for Waddington, Rutgers v. Waddington (N.Y. City Mayor's Ct. 1784), reprinted in 1 JUlius GOeBEL, JR., THE LAW PRACTICE OF AleXANDER Hamilton: DOCUments And COMmentary 362, 368 (1964). Remember, of course, that Calder v. Bull, 3 U.S. (3 Dall.) 386 (1798), featured a debate over the uses of natural law. Justice Salmon P. Chase for the Court wrote that laws "contrary to the great first principles of the social compact," id. at 388, cannot be upheld by a court of law. Justice James Iredell concurred to argue "that whatever the legislative power chose to enact, would be lawfully enacted." Id. at 398 (Iredell, J., concurring). 
Others, such as Pufendorf, have advocated looking at texts from different cultures because of the belief that such analysis was the means to discover natural laws. Identifying commonalities or differences among legal systems allows the comparativist to see universal, natural laws. ${ }^{178}$

The Founders also seemed to share a belief in the "science of politics," tional actors form a "more perfect Union." " Publius sought to control the excesses of popular government through "scientific" means. In Federalist No. 9, Alexander Hamilton, as Publius, wrote: "The science of politics, however, like most other sciences, has received great improvement. The efficacy of various principles is now well understood, which were either not known at all, or imperfectly known to the ancients." ${ }^{\text {A }}$ "science of politics" philosophy would also not distinguish between drafting and interpreting - in deciding on the best interpretation of constitutional language, the experience of other countries could sometimes shed light on what experience demonstrates to be effective strategies of constitutional policy. The Founders thought the Constitution would be interpreted using the lessons of experience, and comparative constitutional law provides a rich set of experiences from which to draw in making decisions. ${ }^{182}$ The Federalist Papers use the insights of comparative constitutional law throughout, mentioning Spain eight times and the Netherlands six times, for example. States debating the ratification of the Constitution also looked to other countries as extra data points and assumed that such comparative data would be used well into the future. ${ }^{183}$

The central documents of the Founding also seem to indicate that the Founders used comparativism and intended that subsequent interpreters, in addition to the original drafters, would use comparative constitutional law. First of all, consider the Declaration of Independence, which has generally either been ignored or dismissed by those looking to interpret the

178. See Michel FoucAult, The ORder of Things 16-25 (1970).

179. The Federalist No. 9, at 51 (Alexander Hamilton) (Clinton Rossiter ed., 1961); see also WOOD, supra note 175, at 593-96 (discussing the "science of politics" used by the Founders); Martin Diamond, The Federalist, in History OF POlitiCal Philosophy 659, 669 (Leo Strauss \& Joseph Cropsey eds., 3d ed. 1987) (describing "Publius" as a spokesman for the new "science of politics" and as making "an important addition to [that] science").

180. U.S. CONST. pmbl.

181. THE FEDERALIST NO. 9, supra note 179 at 72.

182. See Forrest MCDONAld, NovUs Ordo SEClorum: The InTEllectual ORIGins OF THE AMERICAN REVOLUTION 143-83 (1985).

183. E.g., Jonathan Elliot, The Debates in the Several State CONVENTIONS ON THE Adoption of the FEDERAl CONSTITUTION: As ReCOMMENDED By THE GenerAL CONVENTION AT PHILAdELPHIA IN 1787, at 191 (William S. Hein, 1996) (1891) (looking to how European countries structure their legislatures). 
Constitution, ${ }^{184}$ whether by constitutional thinkers from the left, ${ }^{185}$ right, ${ }^{186}$ or center. ${ }^{187}$ The Declaration itself speaks of a "decent respect for the opinions of mankind," ${ }^{188}$ and thereby seems to welcome the use of comparative inquiry in interpreting law as well as drafting it. ${ }^{189}$

Indeed, given that several of the prominent schools of thought that dominated the thinking of the Founders welcomed the use of comparative constitutional law, that the Founders themselves used comparative constitutional law, and that several cases in the early Republic made reference to ways of thinking that would embrace the use of comparative constitutional law, there must be clear and compelling evidence to support Justice Scalia's distinction between the use of comparative constitutional law in the writing and interpretation of the Constitution. Such evidence does not appear.

According to either contemporary version of constitutional originalism, the evidence from the Founding seems to support the contemporary usage of comparative materials by judges. First, consider the 1780 s version of originalism, which focuses solely on what the Founders thought at that time to see what they would do today, without giving this intergenerational effort any "translation." "This version of originalism would not make the Founders aware of other subsequent developments—in other words, given what they knew, said, and did then, how would they answer this one particular constitutional question? The evidence seems to indicate that the

184. AlEXANDER M. BICKEL, THE MORALITY OF CONSENT (1975) (making no reference to the Declaration); ROBERT H. BORK, THE TEMPTING OF AMERICA (1990) (no reference); RONALD DWORKIN, TAKING RIGHTS SERIOUSLY 266 (1997) (one reference); MiCHAEL J. PERRY, THE CONSTITUTION, THE COURTS, AND HumAn Rights (1982) (no reference); LAurenCE H. TRIBE, AMERICAN CONSTITUTIONAL LAW § 15-3, at 1309 (2d ed. 1988) (one reference); Mark Tushnet, Red, White and Blue: A Critical Analysis of CONSTitutional LaW 45 (1988) (one reference). But see AlEXANDER M. BICKEL, THE LEAST DANGEROUS BRANCH 65-68 (2d ed. 1986) (discussing the Declaration as the source of constitutional "principle").

185. E.g., ElY, supra note 89, at 49 (mentioning the Declaration once); WILLS, supra note 175 , at 325 (describing the purpose of the Declaration as "securing ... foreign aid in the ongoing war effort"). Mark Tushnet's recent book does make extensive reference to the Declaration. MARK TUSHNET, TAKING THE CONSTITUTION AWAY FROM THE COURTS passim (1999).

186. E.g., RAOUL BERGER, GOVERNMENT BY JUDICIARY 87 (1977) (arguing that the Declaration is not an important part of constitutional interpretation); Lino A. Graglia, Judicial Activism: Even on the Right, It's Wrong, PUB. INT., Spring 1989, at 57, 71 (presenting the Constitution as a rejection of the ideas of the Declaration).

187. E.g., DANiel J. BOORSTIN, THE GeniUs OF AmERICAN POlitics 84 (1953) (arguing that the Declaration is not an aspect of relevant American constitutional "political philosophy").

188. THE DECLARATION OF INDEPENDENCE para. 1 (U.S. 1776).

189. This would appear especially true in the contemporary setting, when so many countries have developed sophisticated liberal democratic constitutional systems that there would be enough countries whose opinions were in fact entitled to this "decent respect."

190. Lawrence Lessig, Fidelity in Translation, 71 TEX. L. REV. 1165 (1993). 
Founders used comparative constitutional law in drafting the Constitution and would have welcomed its usage in interpreting the Constitution, again with the limitations of refined comparativism-when domestic sources are relatively unclear, and when the comparative materials can be of some use. In Federalist No. 18, for example, Hamilton says, "I have thought it not superfluous to give the outlines of this important portion of history; both because it teaches more than one lesson, and because, as a supplement ... it emphatically illustrates the tendency of federal bodies rather to anarchy among the members, than to tyranny in the head." defends the relevance of these comparative lessons: "I make no apology for having dwelt so long on the contemplation of these federal precedents. Experience is the oracle of truth; and where its responses are unequivocal, they ought to be [examined as] ... important truth[s]." ${ }^{192}$

This usage of experiential bases as the justification for comparative constitutional law pervades the Federalist Papers, including those that focus specifically on the judiciary: "Upon the whole, there can be no room to doubt that the convention acted wisely in copying from the models of those constitutions which have established good behavior as the tenure of judicial offices .... The experience of Great Britain affords an illustrious comment on the excellence of the institution." 193 Experience was to be the lodestar of constitutional decisionmaking, and this notion supports the use of comparative materials in both the drafting and interpretation of the Constitution. ${ }^{194}$ The common law in use at the time of the Founding and in

191. The Federalist No. 18, at 111 (Alexander Hamilton) (Clinton Rossiter ed., 1961).

192. The Federalist No. 20, at 138 (James Madison \& Alexander Hamilton) (Clinton Rossiter ed., 1961) (emphasis added).

193. THE FEDERALiST No. 78, at 472 (Alexander Hamilton) (Clinton Rossiter ed., 1961) (emphasis added).

194. The Federalist Papers open with the statement that the people of New York, and through them the entire American nation, were deciding "whether societies of men are really capable or not of establishing good government from reflection and choice, or whether they are forever destined to depend for their political constitutions on accident and force." THE FEDERALIST No. 1, at 33 (Alexander Hamilton) (Clinton Rossiter ed., 1961). The Founders wanted to learn from experience and political science, and did not differentiate between learning from experience in writing a constitution and interpreting a constitution. Indeed, every Federalist Paper that discusses the distinctiveness of the American experience also makes sure to note that this experience has precedents and relatives, and can learn from the experience of those abroad and indeed has learned from foreign systems in creating the new American system. Compare THE FEDERALIST NO. 14, at 85 (James Madison) (Clinton Rossiter ed., 1961) (arguing that the "fabrics of governments [in the United States] ... have no model on the face of the globe" and that the revolution meant that the United States was following a "new and more noble course"), with id. at 101-02 (arguing that the United States should use the experience of Germany and other European countries in crafting its system of government). 
the next several decades was itself a relatively eclectic mix of materials, ${ }^{195}$ including cases from other countries ${ }^{196}$ and other "sources of truth," such as Christianity, ${ }^{197}$ experience, and common sense. ${ }^{198}$ Therefore, under the purely 1780 s version of originalism, the evidence seems to indicate that interpretation in general and constitutional interpretation in particular used comparative legal sources, and that there was no Scalia-like distinction drawn between the use of comparative constitutional materials in drafting a Constitution and in interpreting one. ${ }^{199}$

195. William Blackstone discussed the common law as including the thoughts of "learned sages of the profession.” 1 WILlIAM BLACKSTONE, COMMENTARIES *64.

196. The common law in use at the time of the Founding examined cases from Britain and other British colonies, and there is no indication that this reference to comparative sources was solely because British Royalist judges instructed American common law judges to use comparative materials.

197. In 1844, the Supreme Court itself recognized that the "Christian religion is a part of the common law of Pennsylvania." Vidal v. Philadelphia, 43 U.S. (2 How.) 127, 198 (1844). A number of states explicitly recognized that the common law included Christianity and other eclectic sources. Courts in Alabama, Goree v. State, 71 Ala. 7 (1881); Arkansas, Shover v. State, 10 Ark. 259 (1850), Delaware, State v. Chandler, 2 Del. (2 Harr.) 553 (1837); North Carolina, Melvin v. Easley, 52 N.C. 378, 382-83 (1860); Pennsylvania, Updegraph v. Commonwealth, 11 Serg. \& Rawle 394 (Pa. 1824); South Carolina, City Council of Charleston v. Benjamin, 33 S.C.L. (2 Strob.) 508 (1846); and Tennessee, Bell v. State, 31 Tenn. 42, 44-47 (1851), recognized that Christianity was part of the common law. Treatise writers also stated that Christianity was part of the common law, and that the common law could include a wide range of sources, citing these state cases as support. They went on to argue that judges interpreting the Constitution, just like judges creating the common law, could use a range of sources. THOMAS M. COOLEY, A TREATISE ON THE CONSTITUTIONAL Limitations Which Rest uPON THE LEGislative POWER OF THE STATES OF THE AMERICAN UNION 472 (Boston, Little, Brown, 1868); THEODORE SEDGWICK, A TREATISE ON THE RULES WHICH GOVERN THE INTERPRETATION AND APPLICATION OF STATUTORY AND CONSTITUTIONAL LAW 17 (New York, J.S. Voorhies, 1857); ChrisTOPHER G. Tiedeman, A Treatise on the Limitations of Police Power in the United States 167 (St. Louis, F.H. Thomas Law Book Co., 1886); Joseph Story, Christianity a Part of the Common Law, 9 AM. JURIST 9 (1833). In fact, immediately after the Constitution was ratified, there were a number of common law cases that cited to comparative law and mentioned the benefits of using comparative law in American law.

198. Supra notes 149-151 and accompanying text.

199. The 1780s version of originalism only allows one to look at materials from that time to decide what the Founders would do today. Still, this version of originalism supports using not only comparative materials from that time, but also using comparative materials from today. For example, to best understand French law at the time, we need to look at what has happened in French law since then and contemporary French law. There are a few examples of Court decisions using comparative constitutional law in the early Republic, for example, Thirty Hogsheads of Sugar v. Boyle, 13 U.S. (9 Cranch) 191, 198 (1815) (holding that "[t]he decisions of the Courts of every country, will be received, not as authority, but with respect"), but nowhere near the number of cites to comparative constitutional law that would occur in later decades and in the next century. This is not at all surprising, however, considering the small number of functioning constitutional courts in the early nineteenth century. Indeed, what is surprising is the use of comparative constitutional law at all during that period of time, considering the relative dearth of comparative materials. The ratio of uses of comparative constitutional law to the available materials (especially when one considers how much harder it was to obtain foreign materials than it is now) compared 
Second, consider the intergenerational or translation ${ }^{200}$ version of originalism: Given what the Founders did and said, if we told them what has happened since then, what would they do-would they look at comparative materials? Given all of the evidence above about their preferences for experience and their decent respect for the opinions of mankind, it appears that they would be even more comparativist than at the Founding because of the development of many mature liberal constitutional democracies. Indeed, the notion of a decent respect for the opinions of mankind, as many have noted, was premised on the fact that the opinions must indeed be held by "mankind"-by sophisticated members of the liberal world community. ${ }^{201}$ Under either version of originalism, one can see the acceptability of refined comparativism. The difficulty of creating a constitutional system led the Founders to look to comparative constitutional law, and to look to comparative sources of information that had the least amount of contextual problems.

\section{B. Founding Through the Civil War}

Before the adoption of the Reconstruction amendments, there are additional examples of American judges using comparative constitutional law to help them decide cases. Initially, judges referred to Roman law, civil law, and English common law extensively. ${ }^{202}$ James Wilson's influential 1791 Law Lectures ${ }^{203}$ also use comparative constitutional law to help interpret the Constitution. $^{204}$ Wilson, generally an important but neglected Framer, ${ }^{205}$ cited Pufendorf twenty-nine times, Grotius ten times, Vattel ten times, and

to now indicates that the Court actually made lots of use of comparative constitutional law in the early Republic.

200. E.g., Lawrence Lessig \& Cass R. Sunstein, The President and the Administration, 94 COLUM. L. REV. 1, 88 (1994).

201. This may be one way of overcoming the originalist argument that the Founders would not have looked to comparative constitutional materials because of their cultural exceptionalism attitudes.

202. See Roscoe Pound, The Influence of the Civil Law in America, 1 LA. L. REV. 1, 2-7 (1938); see also M.H. Hoeflich, ROMAN AND CIVIL LAW AND THE DEVELOPMENT OF ANGLOAMERCIAN JURISPRUDENCE IN THE NINETEENTH CENTURY (1997).

203. 1 THE WORKS OF JAMES WilsON (Robert Green McCloskey ed., 1967).

204. Id. at 41 .

205. A number of twentieth century efforts have been made to elevate James Wilson to the status of some of the other Founders. Randolph G. Adams has made some of the most important efforts. James Wilson, Selected POlitical Essays OF JAmES Wilson (Randolph G. Adams ed., 1930); Randolph G. Adams, The Legal Theories of James Wilson, 68 U. PA. L. REV. 337 (1920). C.P. Smith has written the only full-length biography of Wilson. C.P. SMITH, JAMES WILSON: FOUNDING FATHER, 1742-1798 (1956). 
Burlamqui four times in his sections on interpreting the Constitution. ${ }^{206}$ In the first volume of Joseph Story on the Constitution, there are nineteen citations of Vattel, six of Heineccius, three of Burlamqui, two of Grotius, and two of Rutherford. ${ }^{207}$ Also, with the explosion of the American common law, judges generally used eclectic interpretive methods that did sometimes look to comparative sources as part of settling a case. ${ }^{208}$

\section{After the Civil War}

\section{Relations Between Levels and Branches of Government: Federalism and Separation of Powers}

Justice Felix Frankfurter, perhaps the most active comparativist in the history of the Court, used refined comparativism to address federalism and separation of powers issues throughout his time on the Court. Justice Frankfurter would first see whether or not there was a clear answer from American sources, and then would look abroad, making sure that contextualized differences were minimal by looking at the "kindred problems" other countries faced. ${ }^{210}$ In those cases, Justice Frankfurter would treat the answers of other constitutional systems to a question the Court faced as

206. Again, because James Wilson did have a range of American legal ideas he could reference, his numerous references to comparative legal ideas are quite revealing.

207. JOSEPH STORY, COMMENTARIES ON THE CONSTITUTION OF THE UNITED STATES (1987). Joseph Story makes references to these sources but does not indicate that these sources are important only because they may have impacted the drafting of the Constitution.

208. See Roscoe Pound, The Formative ERA OF AMERICAN LAW 24-26 (1938).

209. E.g., Staub v. City of Baxley, 355 U.S. 313, 325-26 n.1 (1958) (Frankfurter, J., dissenting); Freeman v. Hewit, 329 U.S. 249, 251 n.1 (1946); Polish Nat'l Alliance v. NLRB, 322 U.S. 643, 649-50 (1944); State Tax Comm'n of Utah v. Aldrich, 316 U.S. 174, 182-85 (1942) (Frankfurter, J., concurring).

210. In the area of federal-state relations, for example, Justice Felix Frankfurter invoked the similarities between the federalism of the United States, Canada, and Australia to analyze their rules regarding intergovernmental tax immunity. In one particular case, Justice Frankfurter stated that:

In respect to the problem we are considering, the constitutional relation of the Dominion of Canada to its constituent Provinces is the same as that of the United States to the States. A recent decision of the Supreme Court of Canada is therefore pertinent. In City of Vancouver v. Attorney-General of Canada [1944] S.C.R. 23, that Court denied the

Dominion's claim to immunity in a situation precisely like this, as I believe we should deny the claim of the Government.

United States v. Allegheny County, 322 U.S. 174, 198 (1944) (Frankfurter, J., dissenting); see also Graves v. New York ex rel. O'Keefe, 306 U.S. 466, 491 (1939) (Frankfurter, J., concurring) (noting that the intergovernmental tax immunity case before the Court raises the "same legal issues" as in Australia and Canada under provisions of their constitutional acts). For an even earlier example of the Court using comparative constitutional law, see Kilbourn v. Thompson, 103 U.S. 168 (1880), a case dealing with the contempt power of the U.S. House of Representatives. 
relevant, sometimes even treating those comparative sources as precedents. ${ }^{211}$ At other times, Justice Frankfurter would use negative comparativism, claiming that American commitments were defined by our constitutional differences from other federal structures. ${ }^{212}$

In separation of powers cases, Justice Frankfurter also turned to comparative constitutional law sources. In New York $v$. United States, ${ }^{213}$ Justice Frankfurter wrote for the Court in upholding the right of Congress to tax the state of New York on its sale of mineral waters. After finding American sources did not provide a clear answer, Justice Frankfurter stated that in analyzing the power of the United States over state activities, "[t]he essential nature of the problem cannot be hidden by an attempt to separate manifestations of indivisible governmental powers.... The present case illustrates the sterility of such an attempt." ${ }^{214}$ Frankfurter later referred to the law of Argentina, ${ }^{215}$ as well as to "[a]ttempts along similar lines to solve kindred problems arising under the Canadian and Australian Constitutions" 216 which "proved a barren process.... Even where the Constitution of a federal system explicitly deals with the problem of intergovernmental taxation, as in Brazil, litigation is not escaped and nice distinctions have to be made." 217

Notice the parallels with refined comparativism-Frankfurter notes the difficulty of the case, and in crafting a legal principle looks to countries with minimal contextual differences, those countries that have faced "kindred problems" ${ }^{218}$ and have similar systems of federalism. ${ }^{219}$ Frankfurter's

211. E.g., New York v. United States, 326 U.S. 572, 583-84 n.5 (1946) (noting the barrenness of the "sovereign/proprietary" distinction in other federal systems for purposes of intergovernmental tax immunity); O’Malley v. Woodrough, 307 U.S. 277, 281 nn.6, 8, 282 (1939) (referring to foreign precedents in determining the imposition of an income tax on judges' salaries was constitutional); Graves, 306 U.S. at 490-91 (Frankfurter, J., concurring) (arguing for the abandonment of tax immunity doctrine on the basis of other federal systems).

212. E.g., Irvin v. Dowd, 359 U.S. 394, 408 (1959) (Frankfurter, J., dissenting) (comparing the scope of federal judicial review with other federal systems); Romero v. Int'l Terminal Operating Co., 358 U.S. 354, 361 (1959) (granting federal maritime jurisdiction while noting that "[s]uch a system is not an inherent requirement of a federal government"); Williams v. North Carolina, 317 U.S. 287, 304 (1942) (Frankfurter, J., concurring) (upholding the states' ability to regulate marriage and divorce, despite contrary foreign federal systems).

213. 326 U.S. $572(1946)$.

214. Id. at 580 .

215. Id. at 580 n. 4 .

216. Id. at 583 n.5.

217. Id.

218. Supra note 209.

219. When contextual differences were too great, Frankfurter decided against using comparative constitutional law, or would use negative comparativism to argue for a certain understanding of the American Constitution based on what it was not-most of the time dealing with federalism issues. Supra note 212. 
opinions also represented a broadening of the relevant countries that the Court looked at in its process of using comparative constitutional law. Although the Court had long used a thin version of genealogical comparativism, looking only to England, Frankfurter frequently looked to countries that had similar legal systems and faced similar legal issues, regardless of their historical and political relationship to England and the United States.

Some of the most important cases during the early twentieth century featured the use of comparative constitutional law. In Muller v. Oregon, ${ }^{220}$ Louis Brandeis introduced the now-famous "Brandeis brief." ${ }^{221}$ In attempting to prove a particular constitutional fact - reasonableness-Brandeis, acting as counsel for the state of Oregon, called attention to foreign statutes that imposed restrictions on the number of hours that women may work. He cited statutes from Great Britain, France, Switzerland, Austria, Holland, Italy, and Germany.

Then follow extracts from over ninety reports of committees, bureaus of statistics, commissioners of hygiene, inspectors of factories, both in this country and in Europe, to the effect that long hours of labor are dangerous for women, primarily because of their special physical organization. The matter is discussed in these reports in different aspects, but all agree as to the danger. ${ }^{222}$

Brandeis minimizes contextual differences by noting that these countries are all basically addressing the issue of the effect of "long hours of labor" ${ }^{223}$ on women, and although there are some differences, ${ }^{224}$ the positive comparativism is appropriate because of the basic similarities.

Brandeis's use of comparative constitutional law found support in the opinion for the Court of Justice David Brewer. Justice Brewer noted that the "present case" 225 was difficult, and therefore it "may not be amiss"226 for the Court "to notice legislation as well as expression of opinion from sources other than judicial sources." 227 Justice Brewer recognized the persuasive authority of these sources, stating that they are not "technically

220. 208 U.S. 412 (1908).

221. For a discussion of the idea of the "Brandeis brief," see, for example, LEONARD BAKER, BRANDEIS AND FRANKFURTER: A DUAL BIOGRAPHY (1984); PHILIPPA STRUM, LOUIS D. BRANDEIS: JUsTiCE FOR THE PEOPLE (1984); and Mary Murphy Schroeder, The Brandeis Legacy, 37 SAN DIEGO L. REV. 711 (2000).

222. Muller, 208 U.S. at 419 n.1.

223. Id. (quoting Brandeis brief).

224. Id. (stating that "[ $\mathrm{t}] \mathrm{he}$ matter is discussed in these reports in different aspects"' (quoting Brandeis brief)).

225. Id. at 419 .

226. Id.

227. Id. 
speaking, authorities"228 but that these sources "are significant [as proof] of a widespread belief.",229

\section{Individual Versus the State}

The Court also turned to refined comparativism as a means of adjudicating cases that dealt with the rights of the individual. In the 1893 Fong Yue Ting v. United States ${ }^{230}$ case, for example, the Court debated the relevance of comparative constitutional law in deciding a case dealing with a statute that authorized the deportation of Chinese laborers who did not possess a required residency certificate unless, on the testimony of at least one "white witness," 231 they met the conditions to excuse them from the certificate requirement. ${ }^{232}$ The Court upheld this statute in opinions that featured an interesting debate about the uses of comparative constitutional law. In order to determine the exact scope of the individual right, the Court looked to the practice of "every sovereign and independent nation" and decided that all nations have the "right",234 to expel aliens. In his dissenting opinion, Justice Brewer used negative comparativism, finding that "[t]he governments of other nations have elastic powers-ours is fixed and bounded by a written constitution. The expulsion of a race may be within the inherent powers of a despotism." 235 Also dissenting, Justice Stephen Field argued that "even if that power [of deportation of resident aliens] were exercised by every government of Europe, it would have no bearing in these cases," ${ }^{236}$ but then went on to use negative comparativism to examine the practice of, among others, Russia in banishing Jews as an example of "an act of barbarity" 237 that the U.S. Constitution did not permit. The U.S. Constitution, according to Justice Field, mandated that "no power to perpetuate such barbarity is to be implied from the nature of

228. Id.

229. The Court did not always use comparative constitutional law when it might have been helpful. Compare Child Labor Tax Case, 259 U.S. 20 (1922) (invalidating a federal law designed, through exemptions, to require limits on child labor), with Rex v. Barger (1908) 6 C.L.R. 41 (Austr.) (holding that "implied prohibitions" of the Constitution-to protect state authority and to regulate labor conditions-invalidated federal tax on manufactured goods designed, though exemptions, to impose minimal working conditions requirement).

230. 149 U.S. $698(1893)$.

231. Id. at 729 .

232. Id.

233. Id. at 711 .

234. Id.

235. Id. at 737 (Brewer, J., dissenting).

236. Id. at 757 (Field, J., dissenting).

237. Id. 
our government, and certainly is not found in any delegated powers under the Constitution." ${ }^{238}$

One of the major debates about individual liberties following the Civil War, the extent of the incorporation of the Bill of Rights against the states, ${ }^{239}$ included many references to comparative constitutional law. ${ }^{240}$ Cold War constitutional cases included instances of both positive and negative refined comparativism. In Youngstown Sheet $\mathcal{E}$ Tube Co v. Sawyer, ${ }^{241}$ the Court rejected the argument that President Harry Truman had inherent constitutional authority to issue an executive order seizing private steel mills because of the emergency situation created by the Korean War. Frankfurter concurred to argue that fascist dictatorships in Europe are a reason to constrain presidential power because they demonstrate the possibilities of executive excess. ${ }^{242}$ Justice Robert Jackson wrote that negative examples from "our own times" ${ }^{243}$ of executive powers in

238. Id.

239. For examples of scholarship on this debate, see AKHIL REED AMAR, THE BILL OF RightS: CREATION AND RECONSTRUCTION (1998); and MiCHAEl Kent CuRTIS, NO STATE SHALl ABRIDGE: THE FourTEENTH AMENDMENT AND THE BILl OF RigHTS (1986).

240. Justice Benjamin Cardozo's formulation that all rights "implicit in the concept of ordered liberty," Palko v. Connecticut, 302 U.S. 319, 325 (1937), should be incorporated against the states led Justices to usually look to the practices of other "English-speaking peoples." Ingraham v. Wright, 430 U.S. 651, 673 n.42 (1977) (quoting Wolf v. Colorado, 338 U.S. 25, $27-$ 28 (1949)); see also Poe v. Ullman, 367 U.S. 497, 548 (1961) (Harlan, J., dissenting) (attempting to understand privacy in the home regarding the use of contraceptives by looking to "common understanding throughout the English-speaking world"); Quinn v. United States, 349 U.S. 155, 167 (1955) (arguing that the rules on prosecution for contempt of Congress are governed by "long-standing tradition here and in other English-speaking nations"); Rochin v. California, 342 U.S. 165, 169 (1952) (looking to the "canons of decency and fairness which express the notions of justice of English-speaking peoples"); Adamson v. California, 332 U.S. 46, 61 (1947) (Frankfurter, J., concurring) (looking to the standards of decency "in a civilized society"); Williams v. North Carolina, 325 U.S. 226, 234 (1945) (holding that domicile for constitutional purposes be treated as "an historic notion common to all English-speaking courts"); Malinski v. New York, 324 U.S. 401, 413-14 (1945) (Frankfurter, J., concurring) (arguing that "[t]he safeguards of 'due process of law' and 'the equal protection of the laws' summarize the history of freedom of English-speaking peoples running back to Magna Carta and reflected in the constitutional development of our people"); Rast v. Van Deman \& Lewis Co., 240 U.S. 342, 366 (1916) (concluding that the Constitution embodies "'only relatively fundamental rules of right, as generally understood by all English-speaking communities"” (quoting Otis v. Parker, 187 U.S. 606, 609 (1903))); Harriman v. ICC, 211 U.S. 407, 419 (1908) (holding that the power to require testimony is usual "in Englishspeaking countries at least"). Justice Hugo Black argued that if the Court was to use comparative constitutional law to discover truly fundamental rights, it should look to the practices of all people, not just "English-speaking peoples." Rochin, 342 U.S. at 176 (Black, J., concurring). The Court looked to comparative constitutional law from the first moment it faced the incorporation question. Hurtado v. California, 110 U.S. 516, 522-32 (1884).

241. 343 U.S. 579 (1952).

242. Id. at 593-94 (Frankfurter, J., concurring).

243. Id. at 641 (Jackson, J., concurring). 
totalitarian governments were helpful evidence in deciding the case. ${ }^{244}$ In Rogers v. Richmond, ${ }^{245}$ a key case leading to Miranda v. Arizona, ${ }^{246}$ the Court elaborated on the "voluntariness" standard governing the admissibility of confessions. ${ }^{247}$ Frankfurter used a form of negative comparativism to argue that "ours is an accusatorial and not an inquisitorial system-a system in which the State must establish guilt by evidence independently and freely secured and may not by [its own] coercion prove its charge against an accused out of his own mouth."248 In a later case, the fact that the British did not use the exclusionary rule was used as a reason not to apply it against the states. ${ }^{249}$

A number of Cold War cases looked to the practice of other democracies to help the Court resolve difficult issues surrounding the scope of individual liberties. ${ }^{250}$ The Court, for example, looked to comparative constitutional law to decide the permissibility of the punishment of those

244. Id

245. 365 U.S. 534 (1961).

246. 384 U.S. 436 (1966). Indeed, Miranda itself involved significant discussions of comparative constitutional law. The majority spends approximately five pages discussing foreign experience with providing warnings to suspects. Id. at 486-90. The discussion parallels Frankfurter's opinion in an earlier case. Culombe v. Connecticut, 367 U.S. 568, 581-84 (1961).

Miranda featured a debate not just about comparative constitutional doctrine but also about the uses of comparative constitutional law. Id. at 521 (Harlan, J., dissenting) (arguing that comparative constitutional law is not relevant in this case because of structural differences such as the fact that other systems give prosecutors advantages that they do not have in the United States).

247. Rogers, 365 U.S. at 540 ("[C]onvictions following the admission into evidence of confessions which are involuntary, that is, the product of coercion, either physical or psychological, cannot stand.").

248. Id. at 541. This Frankfurter opinion might actually be used as evidence of the problems that American judges might have in analyzing developments in foreign countries- the proper contrast, rather than the one Frankfurter makes, is between the adversarial system of the common law and the accusatorial Continental model. Frankfurter frequently used comparative constitutional law in his constitutional criminal procedure opinions. E.g., Stein v. New York, 346 U.S. 156, 199 (1953) (Frankfurter, J., dissenting) (arguing that confessions should not be admitted because the "standards of decency deeply felt and widely recognized in Anglo-American jurisdictions" means that such confessions would not have been admitted in criminal trials in Canada, Australia, or India). Other Justices also made reference to comparative constitutional law in their constitutional criminal procedure opinions. E.g., Betts v. Brady, 316 U.S. 455, 465-72 (1942) (looking to a variety of comparative constitutional sources in deciding that the Constitution does not require the appointment of counsel in a state criminal trial).

249. Wolf v. Colorado, 338 U.S. 25, 29-30 (1949).

250. E.g., Rose v. Locke, 423 U.S. 48, 50 (1975) (finding that "[c]rimes against nature" is not vague among "English speaking people"); Hoffa v. United States, 385 U.S. 293, 311 (1966) (finding the use of informers "from time immemorial"); Dennis v. United States, 341 U.S. 494, 584 (1951) (Douglas, J., dissenting) (analyzing freedom of speech as an element essential to all democracies); Joint Anti-Facist Refugee Comm. v. McGrath, 341 U.S. 123, 189 (1951) (Reed, J., dissenting) (looking to the actions taken by other democracies to "control disloyalty among government employees") 
who publicly criticized sitting judges. ${ }^{251}$ In Trop v. Dulles, ${ }^{252}$ the Court confronted a case in which the plaintiff had lost his citizenship because of his conviction by a military court martial of desertion from the U.S. Army during the middle of war. The Court held that a statute authorizing expatriation of individuals convicted of desertion in wartime was beyond the power of Congress. Chief Justice Earl Warren's plurality opinion noted the difficulty of the case and looked at the practice of other nations to conclude that the loss of citizenship was unconstitutional, arguing that "banishment [is] a fate universally decried by civilized people,", 253 and that other countries deplored statelessness and "only two countries" 254 in the world "impose[d] denationalization as a penalty for desertion." 255

In McGowan v. Maryland, ${ }^{256}$ the majority opinion of Chief Justice Warren analyzed the long history of Sunday legislation against the background of a British bill of 1936 and the parliamentary debates in the House of Commons as well as in relation to the labor practices of other countries. $^{257}$ Frankfurter concurred to comment that "[e]ven on the Continent the forces which in the latter half of the nineteenth century pressed for the amelioration of the working conditions of the laborer expressed themselves in part in Sunday legislation,"258 citing the German, Austrian, Swiss, Danish, Norwegian, and Russian experiences as well as the reports of the Congres International de Repos Hebdomadaire. ${ }^{259}$ In Poe v. Ullman, ${ }^{260}$ the Court had to rule on the constitutionality of a Connecticut statute prohibiting the use

251. Bridges v. California, 314 U.S. 252, 284-88 (1941) (Frankfurter, J., dissenting); see also Sacher v. United States, 343 U.S. 1, 23 (1952) (Frankfurter, J., dissenting).

252. 356 U.S. 86 (1958).

253. Id. at 102.

254. Id. at 103.

255. Id. For other examples of the use of comparative constitutional law in cruel and unusual punishment cases, see, for example, Thompson v. Oklahoma, 487 U.S. 815, 830 (1988) (Stevens, J., plurality opinion), which looked to "leading members of the Western European community" to confirm that it would "offend civilized standards of decency" to execute juveniles for crimes committed before age sixteen; Enmund v. Florida, 458 U.S. 782, 796 n.22 (1982), which looked at developments in European countries for support of the argument that the death penalty was unconstitutional as applied to a robber who did not kill or intend to kill; and Coker v. Georgia, 433 U.S. 584, 596 n.10 (1977) (White, J., plurality opinion), which stated that "[i]t is . . not irrelevant here that out of 60 major nations in the world surveyed in 1965, only 3 retained the death penalty for rape when death did not ensue."

256. 366 U.S. 420 (1961).

257. Id. at 450 n.21.

258. Id. at 483 n.40 (Frankfurter, J., concurring). Frankfurter noted that these countries were relevant sources for comparative inquiry because of their similar economies and therefore the minimal contextual differences between the issues as presented to the Court in the United States and the issues in Europe. Id. at 484.

259. Id.

260. 367 U.S. 497 (1961). 
of contraceptives. The famous Justice John Marshall Harlan dissent in $P_{o e}{ }^{261}$ found some of its support in comparative constitutional law:

Although the Federal Government and many States have at one time or other had on their books statutes forbidding or regulating the distribution of contraceptives, none, so far as I can find, has made the use of contraceptives a crime. Indeed, a diligent search has revealed that no nation, including several which quite evidently share Connecticut's moral policy, has seen fit to effectuate that policy by the means presented here. ${ }^{262}$

This use of comparative constitutional law was questioning the means-end linkage between the stated goal of Connecticut's statute and the means used to further that goal. In a footnote, Justice Harlan stated that one can read that an "[u]nqualified disapproval of contraception is implicit in the laws of Belgium, ... . France, . . . Ireland, Italy, [and] Spain..263

Modern substantive due process cases have also used refined comparativism, primarily using the law canvassing method to decide the "constitutional fact" of the fundamentality of the potential liberty interest. In Roe v. Wade, ${ }^{264}$ Justice Harry Blackmun "inquired into, and in this opinion place[d] some emphasis upon" ${ }^{, 265}$ the practices of many other countries, from the Persian Empire to twentieth century European practices. ${ }^{266}$ In Bowers v. Hardwick, ${ }^{267}$ Justice Byron White wrote for the majority and used domestic law canvassing to note that he was "unpersuaded that the sodomy laws of some 25 States should be invalidated on [the morality] basis," ${ }^{268}$ while Chief Justice Warren Burger concurred and looked at comparative constitutional law. ${ }^{269}$

261. For instances of cases that adopted the reasoning of Justice John Marshall Harlan's Poe dissent, see, for example, Planned Parenthood v. Casey, 505 U.S. 833, 848-49 (1992), and Griswold v. Connecticut, 381 U.S. 479 (1965). See also Youngberg v. Romeo, 457 U.S. 307, 320 (1982) (citing Justice Harlan's Poe dissent as the source of the principle that the Court balance "the liberty of the individual" and "the demands of an organized society"); Moore v. East Cleveland, 431 U.S. 494, 500-06 (1977) (Powell, J., plurality opinion) (noting that in the opinion of four Justices, Harlan's Poe dissent is the key statement on judicial review under the Due Process Clause of the Fourteenth Amendment). But see Washington v. Glucksberg, 521 U.S. 702, 722 n.17 (1997) (questioning Justice Souter's reliance, in dissent, on Harlan's Poe opinion because "although Justice Harlan's opinion has often been cited in due process cases, we have never abandoned our fundamental-rights-based analytical method").

262. Poe, 367 U.S. at 554-55 (Harlan, J., dissenting).

263. Id. at 555 n.16 (citations omitted).

264. 410 U.S. 113 (1973).

265. Id. at 117 .

266. Id. at $130,132,133$.

267. 478 U.S. $186(1986)$.

268. Id. at 196.

269. Id. at 196-97 (Burger, J., concurring) (condemning homosexuality as violating ancient Judeo-Christian morality, as well as ancient Roman law). Justice Harry Blackmun's dissent criticized 
This brief history of comparative constitutional law shows that the refined comparativist method has had a long career in American constitutional law. The Founding ethos seems not only to permit the use of comparative constitutional law, but also to demand it. The subsequent history of cases at the Supreme Court level has demonstrated the continued use, and eventual expansion of, the refined comparativist method. All of the cases note that the issues before them are trying, and that this difficulty in deciding the case enables the Court to look abroad for solutions. Then, there is always a reference to the contextual similarities between the issue and other circumstances in the lending country that make the borrowing acceptable. Comparative constitutional law is seen as a helpful source that can lead a court to a decision, but not as a source that is at all binding. These cases also demonstrate the broader definition of genealogical comparativism that the Court has used-its utilization of comparative constitutional law has not been limited solely to tracing ancient British legal practices. Rather, the Court has looked at many countries around the world. In short, there is some precedent in the case law of the U.S. Supreme Court and from the Founding for refined comparativism.

\section{REFINED COMPARATIVISM AND CONTEMPORARY CONSTITUTIONAL SCHOLARSHIP}

Refined comparativism can also be justified no matter what theory of constitutional law one may adopt or what school of contemporary constitutional scholarship one may believe to be the proper methodology for studying American constitutional law. This Part explores three basic notions of what it means to have a constitution, the various schools of constitutional scholarship associated with these three notions, and the acceptability of refined comparativism under these schools of scholarship. First, a constitution can be seen as the document that structures government and society. Second, a constitution can be seen as a document that allows interpreters to decide cases based on the best moral-philosophical understanding of the problem confronted by the interpreter. Third, a constitution can be seen as an embodiment of tradition or of national character. $^{270}$ The discussion in Part IV about refined comparativism and

the majority's interpretations of its sources of comparative law. Id. at 199 (Blackmun, J., dissenting).

270. Obviously, many of the schools of constitutional scholarship I make reference to could be placed into more than one category-for example, law and economics can be seen as a moralphilosophical understanding of the Constitution, and constitutional common law can be seen as part of the national tradition—but these groupings are not as important as the permissibility of 
about originalism touches on the acceptability of refined comparativism under one version of the "constitution as tradition" theory, originalism. This Part expands on that discussion by presenting other versions of the "constitution as tradition" theory, and by defending refined comparativism under the framework of those theories.

\section{A. Constitution as Structure of Government}

First of all, a constitution can be seen as a means of organizing society. Under this view, a constitution should be evaluated in instrumental terms: For example, does it promote efficiency, ${ }^{271}$ or do as good a job as possible of promoting liberty, justice, and the general welfare? According to this vision of constitutional pragmatism, constitutional structures like federalism and separation of powers are important only insofar as they promote liberty, efficiency, or justice. This may also be true of other constitutional structures, including elements of the Bill of Rights. ${ }^{272}$ Justice Breyer alludes to this understanding of a constitution in his Printz invocation of comparative constitutional law. ${ }^{273}$ Under this view of a constitution, refined comparativism is very helpful, for precisely the reasons included in my discussion in Part III.A above. Comparative analysis provides the constitutional interpreter with more possible solutions, more data points, and leads to a richer understanding of one's own assumptions and structures of reasoning.

Pragmatic concerns about particularism - can one possibly transplant a constitutional idea or fact from another system into the United States and make it work? - can be overcome by the structure of refined comparativism. ${ }^{274}$ The refined comparativist judge is using comparative constitutional law when contextual differences are at a minimum, and when there is little reason to be concerned about the applicability of lessons from abroad for the American experience. Using the insights of an expert, the refined comparativist judge can handle some of the perplexing issues posed by transplanting constitutional lessons across borders.

Negative comparativism may be especially helpful in promoting this vision of constitutional pragmatism. Comparative constitutional analysis

refined comparativism to each school of constitutional scholarship, regardless of what group they are placed in for the purposes of this argument.

271. RichARD A. POSNER, ECONOMIC ANALYSIS OF LAW 615-22 (4th ed. 1992).

272. E.g., Akhil Reed Amar, The Bill of Rights as a Constitution, 100 YALE L.J. 1131 (1991) (arguing that many elements of the Bill of Rights can be understood as attempting to promote liberty, efficiency, and justice).

273. Printz v. United States, 521 U.S. 898, 977 (1997) (Breyer, J., dissenting) (looking at the "empirical" consequences of certain constitutional structures).

274. See also infra Part VII.B.1. 
may point out the types of situations the U.S. Constitution attempts to avoid, whether it is the nightmares of apartheid, ${ }^{275}$ the extremes of Nazi Germany, ${ }^{276}$ or the Siberian gulag. ${ }^{277}$ Although the real concern is whether pathologies will occur here, and therefore the heritage of Dred Scott ${ }^{278}$ and Korematsu $^{279}$ are helpful cases to study, surely the types of situations that generated pathologies abroad can be helpful sources of analysis for an American court attempting to avoid creating a similar outcome. Furthermore, it can be argued that one of the basic elements of American constitutionalism is a concern for avoiding the type of horrific pragmatic outcomes that negative comparativism uses comparative constitutional law to make sure the United States avoids. The U.S. Constitution is a way of guarding against the parade of horribles-think of, for example, First Amendment doctrine rejecting "content regulations" and "prior restraints" because of the history of governmental and private intolerance of popular and unpopular speech, or the fear of racial classifications because of the American experience with slavery and societal racism.

Another approach to contemporary constitutional scholarship that can be seen as a way of organizing government and society is the "constitutional

275. Shaw v. Reno, 509 U.S. 630, 647 (1993) (finding that racial reapportionment "bears an uncomfortable resemblance to political apartheid"); Metro Broad., Inc. v. FCC, 497 U.S. 547, 633 n.1 (1990) (Kennedy, J., dissenting) (invoking race-conscious definitions used in Nazi Germany and South Africa); Holland v. Illinois, 493 U.S. 474, 507-08 n.6 (1990) (Stevens, J., dissenting) (analogizing South Africa and Nazi Germany precedents to current efforts to determine race for legal purposes).

276. E.g., Florida v. Bostick, 501 U.S. 429, 443 (1991) (Marshall, J., dissenting) (quoting a state court opinion referring to suspicionless searches as techniques used by "Hitler's Berlin" (citation omitted)). In the late 1940s (and in particular in opinions authored by Justice Robert Jackson after his service as a special prosecutor at the Nuremberg trials), the Court issued many decisions that discussed the importance of constitutional restraints on limitless searches as a means of preventing the police excesses that were commonplace in totalitarian regimes. For examples of these types of post-Nuremberg opinions by Justice Jackson, see Johnson $v$. United States, 333 U.S. 10, 17 (1948), in which he distinguished "our form of government, where officers are under the law, and the police-state where they are the law," and United States v. Di Re, 332 U.S. 581, 595 (1948), in which he stated he preferred to allow some criminals to escape punishment to "a too permeating police surveillance." Cf. Shaughnessy v. United States ex rel. Mezei, 345 U.S. 206, 225-26 (1953) (Jackson, J., dissenting) (objecting to the executive detention of aliens without a hearing as bearing "unmistakable overtones of the 'protective custody' of the Nazis").

277. W. Va. Bd. of Educ. v. Barnette, 319 U.S. 624, 641 (1943) ("[The u]ltimate futility of such attempts to compel coherence [of sentiment] is the lesson of every such effort from the Roman drive to stamp out Christianity . . . the Inquisition . . . the Siberian exiles . . . down to the fast failing efforts of our present totalitarian enemies.").

278. Scott v. Sandford, 60 U.S. (2 How.) 393 (1856).

279. Korematsu v. United States, 323 U.S. 214 (1944). 
common law" approach to understanding constitutional decisions. ${ }^{280}$ The constitutional common law approach seems to be a very accurate way of describing the current state of American constitutional jurisprudence. Many of the characteristics of traditional common law evolution now describe constitutional evolution: (1) Significant constitutional doctrinal changes now only occur after old constitutional doctrines prove unworkable or after general extralegal changes make old constitutional doctrines inapplicable or incorrect. (2) All theories of constitutional interpretation respect precedent. Of course, these similarities between the common law method and contemporary constitutional jurisprudence do not mean that federal courts still create federal common law. Since the Court decided Erie Railroad v. Tompkins, ${ }^{281}$ there has been "no federal general common law,"282 but the Court still has had a role in creating specialized areas of common law. ${ }^{283}$

Given this inevitability of some form of constitutional common law, refined comparativism becomes acceptable and even desirable. In order to learn from experience to help courts keep up with rapidly changing social dynamics, courts need a large range of legal possibilities and data pointsthey need as many "laboratories" ${ }^{284}$ as possible. Also, in making constitutional common law, courts have looked to a wide range of sources to help them make decisions-general considerations of public policy ${ }^{285}$ and other sources ${ }^{286}$ - because courts realize they are creating law. Moreover, in making law under the vision of constitutional common law, courts realize that they can overcome their limited fact-finding and legislative abilities by

280. E.g., HARry H. Wellington, InTERPRETING THE CONSTITUTION 127 (1990); David A. Strauss, Common Law Constitutional Interpretation, 63 U. CHI. L. REV. 877 (1996); Harry H. Wellington, Common Law Rules and Constitutional Double Standards, 83 YALE L.J. 221 (1973).

281. 304 U.S. 64 (1938).

282. Id. at 78 .

283. Henry J. Friendly, In Praise of Erie — and of the New Federal Common Law, 39 N.Y.U. L. REV. 383, 405-22 (1964).

284. Supra note 130.

285. Strauss, supra note 280, at 905-06.

286. If the Constitution is truly a system of common law, then the recognition that statutes can now be used in common law judicial decisionmaking even strengthens the argument that judges can look to comparative constitutional law; the common law has become more eclectic. Statutes used to be considered an exceptional intrusion into the body of common law judicial decisions. Compare Roscoe Pound, Common Law and Legislation, 21 HARV. L. REV. 383, 387-88 (1908), with James M. Landis, A Note on "Statutory Interpretation," 43 HARV. L. REV. 886 (1930). Whenever a statute did not directly apply to the case at hand, therefore, the judge used the common law. See P.S. Atiyah, Common Law and Statute Law, 48 MOD. L. REV. 1, 8-12 (1985). This is the source of the rule that statutes in derogation of the common law should be strictly construed. See John Henry Merryman, The Civil Law Tradition 32 (2d ed. 1985). Now, however, statutes are a source of law in American common law. 
relying on experience, the basis of the common law, in looking to another country's history addressing a particular issue.

\section{B. Constitution as Moral-Philosophical System}

Another understanding of the Constitution offered in modern constitutional scholarship sees the Constitution as giving life to a moralphilosophical system. Examples of this include Ronald Dworkin's "Hercules,"287 Justice William Brennan's "living Constitution,"288 and Benjamin Cardozo's "sociological jurisprudence." ${ }^{289}$ It also probably includes the perspectives of critical legal studies, ${ }^{290}$ critical race theory, ${ }^{291}$ feminist theory, ${ }^{292}$ libertarianism, ${ }^{293}$ and the theory I will examine-civic republicanism. Civic republicanism refers to the ideas given new life by historians like Bernard Bailyn, ${ }^{294}$ Gordon Wood, ${ }^{295}$ and Joyce Appleby. ${ }^{296}$ Constitutional scholars inspired by this civic republican revival include Cass Sunstein, ${ }^{297}$

287. RONALD DWORKIN, TAKING RIGHTS SERIOUSLY 105-30 (1977).

288. The phrase "living Constitution" has been cited as Justice William Brennan's term, even though he actually did not use the term. Laurence H. Tribe \& Michael C. Dorf, Levels of Generality in the Definition of Rights, 57 U. CHI. L. REV. 1057, 1101 (1990) (stating that "the living Constitution" is "one of the many contributions that ... earned Justice Brennan his place as one of the most influential Supreme Court Justices in our history"); see also Arlin M. Adams, Justice Brennan and the Religion Clauses: The Concept of a "Living Constitution," 139 U. PA. L. REV. 1319, 1320 (1991).

289. Benjamin N. CARdozo, The NATURe of THE Judicial Process 62, 64 (1921) (distinguishing between the "method of sociology" and the "method of tradition").

290. E.g., Mark Tushnet, Critical Legal Studies: An Introduction to Its Origins and Underpinnings, 36 J. LEGAL EDUC. 505 (1986).

291. E.g., PATRicia J. Williams, THE AlCHEMy OF RACE AND Rights (1991).

292. E.g., CATHARINE A. MACKINNON, FEMINISM UNMODIFIED: DisCOURSES ON LifE AND LAW (1987); CATHARINE A. MACKINNON, TOWARD A FEMINIST THEORY OF THE STATE (1989).

293. Richard A. Epstein, Takings: Private Property And the Power of Eminent DOMAIN (1985)

294. BAILYN, ORIGINS, supra note 175.

295. WOOD, supra note 175.

296. Joyce Appleby, InHERiting the Revolution: THE First Generation of AMERICANS (2000).

297. Cass R. Sunstein, Beyond the Republican Revival, 97 YALE L.J. 1539 (1988) [hereinafter Sunstein, Beyond]; Cass R. Sunstein, Interest Groups in American Public Law, 38 STAN. L. REV. 29 (1985) [hereinafter Sunstein, Interest Groups]; Cass R. Sunstein, Legal Interference with Private Preferences, 53 U. CHI. L. REV. 1129 (1986); Cass R. Sunstein, Lochner's Legacy, 87 COLUM. L. REV. 873 (1987); Cass R. Sunstein, Naked Preferences and the Constitution, 84 COLUM. L. REV. 1689 (1984) [hereinafter Sunstein, Naked Preferences]; Cass R. Sunstein, Preferences and Politics, 20 PHIL. \& PUB. AFF. 3 (1991). 
Bruce Ackerman, ${ }^{298}$ Frank Michelman, ${ }^{299}$ and perhaps even Owen Fiss, ${ }^{300}$ all of whom argue that the Constitution can best be understood as an embodiment of civic republican ideals. At bottom, all of these scholars argue that the Constitution contemplates a civic republican model of policymaking in which decisions are made in the legislative process through principled deliberation and reasoned dialogue. ${ }^{301}$ From this perspective, refined comparativism can actually help remedy some of the problems of civic republicanism.

Refined comparativism adds an additional viewpoint to the "principled" public debate. In this way, it makes the debate more likely to reach the true "public good" 302 - taking its inspiration from better solution comparative law. ${ }^{303}$ It adds a distinctive new voice to the public debate, and because of the modern civic republican's overwhelming concern with dialogue ${ }^{304}$ this helps enliven the civic republican debate. The civic republican position is that present desires should be open and subject to change

298. 2 ACKERMAN, supra note 175; Bruce Ackerman, Constitutional Politics/Constitutional Law, 99 YALE L.J. 453 (1989); Bruce A. Ackerman, The Storrs Lectures: Discovering the Constitution, 93 YALE L.J. 1013 (1984) [hereinafter Ackerman, Storrs Lectures].

299. Frank I. Michelman, Law's Republic, 97 YALE L.J. 1493 (1988); Frank I. Michelman, The Supreme Court, 1985 Term-Foreword: Traces of Self-Government, 100 HARV. L. REV. 4 (1986) [hereinafter Michelman, Foreword].

300. Owen M. Fiss, The Death of the Law?, 72 CORnEll L. ReV. 1 (1986); Owen M. Fiss, The Supreme Court, 1978 Term-Foreword: The Forms of Justice, 93 HARV. L. REV. 1 (1979). Although Owen Fiss might not be as openly republican in his writings as Sunstein, Ackerman and Michelman, others have called Fiss a civic republican theorist. TUSHNET, supra note 184, at 160 68. Fiss, like Sunstein and others commonly called civic republicans, dislikes the jury, the central institution of civic republicanism. Still, the Tushnet book and other materials commonly refer to Fiss, Sunstein, Michelman, and Ackerman as civic republicans.

301. Other important scholars have indicated their affinity for the civic republican revival. SANFORD LEVINSON, CONSTITUTIONAL FAITH (1988); TUSHNET, supra note 184, at 17, 187; Suzanna Sherry, Civic Virtue and the Feminine Voice in Constitutional Adjudication, 72 VA. L. REV. $543(1986)$.

302. See, e.g., Ackerman, Storrs Lectures, supra note 298, at 1022, 1033; Sunstein, Interest Groups, supra note 297, at 31-32, 58; Sunstein, Naked Preferences, supra note 297, at 1690-91.

303. Supra notes 128-129 and accompanying text.

304. While civic virtue was an essential element of classical republicanism, the new republican theorists barely mention virtue as an indispensable element of civic republicanism. Classical republicanism viewed virtue as the most essential element of the pursuit of the common good, while for civic republicans dialogue is the most essential element. This is not to say that contemporary civic republicans ignore virtue, or dislike virtue, but rather that virtue is not the central ingredient of their vision of civic republicanism. Sunstein writes:

[C]ivic virtue should play a role in political life. There is no mystery to this claim; it refers simply to the understanding that in their capacity as political actors, citizens and representatives are not supposed to ask only what is in their private interest, but also what will best serve the community in general.

Sunstein, Beyond, supra note 297, at 1550. Of all of the major civic republican constitutional theorists, Michelman focuses the most on virtue. E.g., Michelman, Foreword, supra note 299, at $55-73$. 
in light of collective discussion and debate. ${ }^{305}$ For this openness to be possible and to make it work at its best, the public discussion must feature alternative perspectives and additional information ${ }^{306}$-one of the primary strengths of refined comparativism from a civic republican perspective.

Refined comparativism also has a way of strengthening the public debate, in ways noted earlier, by debunking any sense of false necessity ${ }^{307}$ and bringing into question even the most basic assumptions. ${ }^{308}$ It makes all preferences and ideas open to revision subject to public deliberation. Moreover, it frees up the public dialogue by inserting the voice of an "outsider." Deliberative criticism requires distance; decisionmakers must be willing to scrutinize their own and their constituents' preferences. ${ }^{309}$ This distance can be provided by introducing the voice of an outsider, the voice of comparative constitutional law. This "outside voice" virtue of refined comparativism can also help ensure the requirement of the civic republican precondition of political equality. A "multicultural" civic republicanism can ensure the representation of diverse viewpoints by giving voice to the insights of other countries, thereby perhaps publicizing the feelings of immigrants or of other citizens who still feel attached to their home countries' values and jurisprudence. Alexander Hamilton said that "[t]he oftener [a law] is brought under examination [and] the greater the diversity [of viewpoints] . . . the less must be the danger of those errors which flow." ${ }^{10}$ Multicultural civic republicanism can also be helped especially by negative comparativism, which may help generate the minimum "overlapping consensus" "311 necessary as a basic precondition for public debate. If we all agree that, no matter what, we do not want to be like Nazi Germany or racist South Africa, that may help generate conversation, mutual understanding, and respect.

305. E.g., Samuel Beer, The Strengths of Liberal Democracy, in A PROSPECT OF LIBERAL DEMOCRACY (William S. Livingston ed., 1979).

306. This might be one way of overcoming the skepticism of some scholars about civic republicanism that any efforts to find a notion of the "common good" have always resulted in "hierarchy, exclusion and alienation." Derrick Bell \& Preeta Bansal, The Republican Revival and Racial Politics, 97 YALE L.J. 1609, 1612 (1988). Introducing the comparativist voice into civic republican constitutional discourse would diversify the constitutional discourse, just in case the domestic civic republican constitutional discourse did not.

307. Supra note 138 and accompanying text.

308. Supra notes 137-141 and accompanying text.

309. Sunstein, Beyond, supra note 297, at 1575 (describing this distance as the "foundation of contemporary republicanism").

310. THE FedERALIST No. 73, at 443 (Alexander Hamilton) (Clinton Rossiter ed., 1961).

311. Supra note 164 and accompanying text. 
Refined comparativism also fits with the role of education in both liberal and civic republican visions of the state. First, Bruce Ackerman has described liberal education as follows:

We have no right to look upon future citizens as if we were master gardeners who can tell the difference between a pernicious weed and a beautiful flower. A system of liberal education provides children with a sense of the very different lives that could be theirs-so that, as they approach maturity, they have the cultural materials available to build lives equal to their evolving conceptions of the good. ${ }^{312}$

The liberal vision of education requires the introduction of a range of perspectives. Courts, playing the role of constitutional educators in their duty as constitutional interpreters, ${ }^{313}$ can enhance this eclectic liberal education by looking to comparative constitutional law.

The civic republican also has a distinctive view of education. Education under civic republicanism is necessary because citizens must use rights in a certain way, and therefore civic republicans focus on responsibility and virtue in addition to liberty. The entirely subjectivist education is incompatible with the civic republican idea of citizenship. Civic republican education must recognize that some ways of acting are impermissible and ought to be discouraged in the educational process. At minimum, there must be something that civic republican education teaches citizens they should do and something they should not do. This minimum overlapping consensus can be provided by negative comparativism, as discussed earlier. ${ }^{314}$

More importantly, although an education that indoctrinates the citizen only with norms would be part of the totalitarian state, in a multicultural civic republican state citizenship involves principled and rational deliberation about values and virtue in a world where citizens disagree about both. The multicultural civic republican state must also then educate its citizens to think critically. As Amy Gutmann has said, "[c]hildren must learn not just to behave in accordance with authority but to think critically about authority if they are to live up to the democratic ideal of sharing

312. Bruce A. ACKerman, Social Justice in the Liberal State 139 (1980). Ackerman is not entirely clear on how we can combine this with a parental "right to try to impress our children with the things that are most important to us," without violating liberal principles of neutrality that he holds so dear. Id. at 140.

313. E.g., Christopher L. Eisgruber, Is the Supreme Court an Educative Institution?, 67 N.Y.U. L. REV. 961 (1992) (discussing whether the Court can and should educate the public); Eugene V. Rostow, The Democratic Character of Judicial Review, 66 HARV. L. REV. 193, 208 (1952) (famously noting that the "Supreme Court is, among other things, an educational body, and the Justices are inevitably teachers in a vital national seminar").

314. Supra note 164 and accompanying text. 
political sovereignty as citizens." ${ }^{315}$ Bruce Ackerman argues along similar lines, asserting that parents have an obligation to provide their children "with cultural equipment that permits the child to criticize, as well as affirm, parental ideas." Children must have the ability to "deliberate critically among a range of good lives and good societies."317 For refined comparativism, this means that courts as constitutional educators can help further the collective ability to think critically by introducing a range of perspectives and ideas.

\section{Constitution as Tradition/National Character}

The Constitution might also be understood as an embodiment of our basic traditions and national character. This approach has become more prominent in recent Supreme Court cases. In Washington v. Glucksberg, ${ }^{318}$ for instance, the Court rejected an argument that persons have a fundamental right to physician-assisted suicide because of a "consistent and almost universal tradition that has long rejected the asserted right, and continues explicitly to reject it today." 319 The Court held that the "[n]ation's history, legal traditions and practices ... direct and restrain our exposition of the Due Process Clause." ${ }^{230}$ In the academic literature, this emphasis on tradition is represented in works that give specific content to the American tradition, such as Bruce Ackerman's work on "dualist democracy."

From the Declaration of Independence to the present day, American constitutional law has looked to comparative constitutional law. It seems that it is at least some part of the American national character to have a "decent respect for the opinions of mankind." "322 Also, with the sociolegal changes mentioned throughout this Article, such as multiculturalism, the use of comparative constitutional law might actually be mandatory as a means of discovering the true identity and mores of "We the people." Finally, even if one does not accept the comparativist tendencies of the American national character, or accept the relevance of comparativist insights in a multicultural America, one can still accept refined

315. Amy Gutmann, Democratic Education 51 (1987). Amy Gutmann follows John Dewey in advocating teaching critical thinking as a central part of democratic education. Id. at 13.

316. ACKERMAN, supra note 312, at 117.

317. GUTMANN, supra note 315, at 44.

318. 521 U.S. 702 (1997).

319. Id. at 723 .

320. Id. at 721 .

321. E.g., Ackerman, Storrs Lectures, supra note 298, at 1022-24.

322. See TUSHNET, supra note 185, at 181. 
comparativism. The American tradition will not always lead to clear principles that judges can apply in specific cases. For example, the American experience may instruct us about the limited role the judiciary is to play in overseeing sentencing, but does this generate a specific judicial principle to apply to specific cases? ${ }^{323}$

Comparative constitutional law can also be used in its role as supplying additional constitutional facts. If there is a specific narrative characterizing the American experience, a court can decide how best to further that narrative by looking to the experiences of other countries. Whether in its capacity as generator of judicial principles or of constitutional facts, however, comparative constitutional law can still be helpful by using negative comparativism to help define the conflicting and sometimes incoherent American experience.

\section{ApPLICATION}

In 1992, the Supreme Court heard the case of R.A.V. v. City of St. Paul. $^{324}$ In that case, Robert Allan Viktora (R.A.V.) ${ }^{325}$ was convicted under the St. Paul Bias-Motivated Crime Ordinance ${ }^{326}$ of burning a crudely made cross on the lawn of an African American family that had moved into a formerly all-white neighborhood. ${ }^{327}$ According to the St. Paul ordinance, anyone who "places on public or private property a symbol, [or] object ... including ... a burning cross ... which one knows or has reasonable grounds to know arouses anger, alarm or resentment in others on the basis of race, color, creed, religion or gender commits disorderly conduct." ${ }^{328}$ The Supreme Court struck down the St. Paul statute as interpreted by the Minnesota Supreme Court because it "prohibit[ed] ... speech solely on the basis of the subjects the speech addressed." 329 How would the refined comparativist have handed this case? The Supreme Court did make brief reference to comparative constitutional law. Justice Scalia's opinion for the majority noted that "[f]rom 1791 to the present . . . our society, like other free but civilized societies, has permitted restrictions upon the content of speech in a few limited areas." ${ }^{330}$ There is no reference, however, to the decisions

\footnotetext{
323. United States v. Then, 56 F.3d 464, 468-69 (2d Cir. 1995) (Calabresi, J., concurring).

324. 505 U.S. 377 (1992).

325. At the time of the crime the defendant was a juvenile, so the Court identified him only by his initials.

326. ST. PAUl, MiNN., LEGIS. CODE $§ 292.02$ (1990), quoted in R.A.V., 505 U.S. at 380.

327. R.A.V., 505 U.S. at 379.

328. ST. PAUL, MinN., LEGIS. CODE $§ 292.02$, quoted in R.A.V., 505 U.S. at 380.

329. R.A.V., 505 U.S. at 381.

330. Id. at 382-83 (emphasis added).
} 
of other constitutional courts on hate speech. ${ }^{331}$ But what would have happened if the Court had used the refined comparativist method-would the decision have been "better"?

First, a refined comparativist Court would have to look to the American sources to see if this was indeed a "hard case" that warranted a look at comparative constitutional law materials. The Court in this case completely missed the constitutional value conflicts. It construed the case as all about the First Amendment, when in fact the case turns also on the Thirteenth and Fourteenth Amendments. Clearly, as Scalia's opinion notes, there are important First Amendment values attacked by the St. Paul statute. These First Amendment concerns about government regulation of speech are strengthened when one examines the effect that the Fourteenth Amendment has in restricting the ability of government to regulate unpopular speech, as Akhil Reed Amar has noted. ${ }^{332}$ More fundamentally, however, the Fourteenth Amendment also concerns itself with race and equality, and Viktora directed his attack against African Americans, the paradigmatic class protected by the Fourteenth Amendment. The Thirteenth Amendment also comes into play, because Viktora's actions against African Americans may in fact be "badges and incidents" slavery that a state can properly regulate. Justice Stevens's opinion does make some mention of this notion, stating that "[t]he cross-burning in this case-directed as it was to a single African-American family trapped in their home-was nothing more than a crude form of physical intimidation." ${ }^{334}$ Viewed in this light, the fact that the statute may be read to punish only hate crimes against minorities and not hate crimes by

331. Although Canadian Supreme Court decisions are available in English in major law libraries (and were accessible on-line through QUICKLAW beginning in 1989), the Canadian Supreme Court case on hate speech that preceded R.A.V., Regina v. Keegstra [1990] 3 S.C.R. 697, was apparently mentioned in only one of the many briefs filed in R.A.V. (based on an examination of the Table of Authorities of those briefs available on Lexis). Brief Amicus of the National Black Women's Health Project in Support of Respondent, R.A.V. v. St. Paul, 505 U.S. 377 (1992) (No. 90-7675); see also Brief Amicus Curiae of the Asian-American Legal Defense and Education Fund et. al., R.A.V. v. St. Paul, 505 U.S. 377 (1992) (No. 90-7675) (listing a 1989 law review article comparing U.S. and Canadian approaches to hate speech).

332. Amar, supra note 272, at 1147-52. This only further illustrates the complexity and difficulty of the case. While the Reconstruction, with its emphasis on equality and race, may make one lean towards upholding the St. Paul statute, the Reconstruction was also about protecting unpopular speech. These protections for unpopular speech helped shield the black-led civil rights movement of the 1960s. The most important First Amendment case of recent times, New York Times Co. v. Sullivan, 376 U.S. 254 (1964), ended up protecting unpopular criticism by blacks. Id. at 256-58. Many of the most important First Amendment cases of the civil rights era involved African American litigants suing to protect their unpopular speech. HARRY KALVEN, JR., THE NEGRO AND THE FIRST AMENDMENT (1965).

333. The Civil Rights Cases, 109 U.S. 3, 35-36 (1883) (Harlan, J., dissenting).

334. R.A.V., 505 U.S. at 432 (Stevens, J., concurring). 
minorities may be acceptable, because the Thirteenth and Fourteenth Amendments introduce into the Constitution the notion of greater protection for certain groups or classes than for others.

The Court did not recognize the conflict in American constitutional values. Perhaps a refined comparativist Court, aware that this was a hard case, would have been more willing to recognize the existence of a value conflict than was the R.A.V. Court, which completely missed the equality values that the St. Paul statute promoted. The refined comparativist Court, then, would have realized that this case presented a number of difficult issues, because of the value conflict and because of open-ended constitutional text, and would have started to look to comparative constitutional law as a possible source of assistance.

A federal judicial system using refined comparativism would have noted the relevant sources of comparative constitutional law long before the Supreme Court heard oral arguments and issued its decision in this particular case, thereby providing the Court with a record on comparative constitutional law that the Court could have utilized. The Court would have turned to its context consideration ${ }^{335}$-are there so many differences, legal and otherwise, between other countries and the United States that comparative constitutional law is of no use? The refined comparativist Court would have looked to these context considerations and decided that contextual differences exist but are not significant enough to prevent the use of comparative constitutional law. Most of the countries addressing the constitutionality of hate speech have broad language in their constitutions, just as the United States does in its Constitution. Countries like Canada have a similar culture and also have British common law legal roots that are quite similar to those of the United States. Although Canada's legal system is slightly different, and it never revolted against the Crown (and indeed served as a safe haven for British Tories), these differences are not fatal for the refined comparativist. Canada and Germany, among other countries, also have a history, like the United States, of protecting the freedom of speech, and a past full of slavery and racial discrimination.

During the stage of refined comparativism in which a court decides if there is anything to be gained from looking abroad, it can of course use a

335. With all of these issues — context consideration, comparative evolutionary advantages (sociolegal and legal) — the Court would have had a lower court decision on the matter to help it along. This lower court decision may have simply found that this was not a "hard case" and therefore there was no need to consult comparative constitutional law. In that instance, the lower courts would not have assembled any comparative constitutional law materials or made any comment on comparative constitutional law that would have helped the Court. 
foreign law expert. If refined comparativism had been used in the lower courts, then judges may have used an expert ${ }^{336}$ and the parties may have briefed some issues of comparative constitutional law, so the Supreme Court would have had a record to rely on in deciding whether or not there was anything to be gained from looking abroad. This record would have undoubtedly showed that there was a comparative evolutionary legal advantage and a comparative evolutionary sociolegal advantage. In the United States, prior to 1980 only five states had any type of statutes related to hate crimes, ${ }^{337}$ while countries around the world had addressed the issue for some time. Also, the effectiveness of hate speech regulation programs had been observed in countries around the world, and contextual developments such as multiculturalism had been addressed in the opinions of Canadian courts, for example, long before the U.S. Supreme Court heard this case.

336. There have been plenty of articles written on the cultural, legal, and historical aspects of American and Canadian restrictions of hate speech, and on hate speech in general, and therefore there must be some individuals qualified to serve as foreign law experts in this case. For relevant scholarship (though not necessarily by individuals qualified to serve as experts), see, for example, LeE C. BOllinger, THE TOlERANT SOCIETY: FREEDOM OF SPEECH AND EXTREMIST SPEECH IN AMERICA (1986); KENT GREENAWALT, FIGHTING WORDS: INDIVIDUALS, COMMUNITIES, AND LIBERTIES OF SPEECH (1995); MARI J. MATSUDA ET AL., WORDS THAT Wound: CRitical RACE THEORY, Assaultive SPEECH, AND THE First AmENDMENT (1993); Akhil Reed Amar, The Case of the Missing Amendments: R.A.V. v. City of St. Paul, 106 HARV. L. REV. 124 (1992); Joshua Cohen, Freedom of Expression, 22 PHIL. \& PUB. AfF. 207 (1993); Elena Kagan, Private Speech, Public Purpose: The Role of Governmental Motive in First Amendment Doctrine, 63 U. CHI. L. REV. 413 (1996); Kenneth L. Karst, Boundaries and Reasons: Freedom of Expression and the Subordination of Groups, 1990 U. ILL. L. REV. 95; Charles R. Lawrence III, If He Hollers Let Him Go: Regulating Racist Speech on Campus, 1990 DukE L.J. 431; Mari J. Matsuda, Public Response to Racist Speech: Considering the Victim's Story, 87 MICH. L. REV. 2320 (1989); Robert C. Post, Racist Speech, Democracy, and the First Amendment, in SPEAKING OF RACE, SPEAKING OF SeX: Hate SPEECH, Civil Rights, AND Civil Liberties 115 (Henry Louis Gates, Jr. et al. eds., 1994); and John A. Powell, Worlds Apart: Reconciling Freedom of Speech and Equality, 85 KY. L.J. 9 (1996). Many of these pieces of scholarship also advocate incorporating the Canadian version of hate speech jurisprudence into American constitutional law. My contribution in this Article is to view this incorporation in the context of refined comparativism, and make some different arguments about the virtues of such a borrowing.

This wealth of literature on Canadian and American hate speech has two effects on my argument. First, it means that my proposal of borrowing from Canadian constitutional law on hate speech is not new in and of itself, but rather is new in that I use it to illustrate how refined comparativism works. Second, this wealth of literature means that there would be no problem finding relevant experts for the litigants and court to use in the trial and appeal.

337. See Frederick M. Lawrence, Resolving the Hate Crimes/Hate Speech Paradox: Punishing Bias Crimes and Protecting Racist Speech, 68 Notre DAme L. ReV. 673, 680 (1993). Connecticut, Florida, Georgia, North Carolina, and Virginia enacted statutes designed to combat the Ku Klux Klan, and these statutes have been used to address cross burnings and using hoods or masks in public. Id. at 680 n.32. 


\section{A. Canada, Hate Speech, and Refined Comparativism}

A refined comparativist Court could have used comparative constitutional law both to help it find a workable principle of law to apply and also to provide it with a series of constitutional facts. Looking to Canada would be especially helpful in this case. The Canadian Charter of Rights and Freedoms, enacted in 1982, "guarantees the rights and freedoms set out in it subject only to such reasonable limits prescribed by law as can be demonstrably justified in a free and democratic society." 338 One of these "rights and freedoms" subject to that limitation is Charter Section 2(b)'s guarantee that "[e]veryone has the following fundamental freedoms... (b) freedom of thought, belief, opinion and expression." ${ }^{339}$ Charter Section 15(2) speaks of equality, ${ }^{340}$ and Charter Section 27 notes that the Charter attempts to protect the multicultural heritage of Canada. ${ }^{341}$

The Canadian Supreme Court has applied these provisions in the test created by Regina v. Oakes ${ }^{342}$ to create a workable principle to see if a restriction on freedom of speech is permissible. First, the court must determine whether the purpose of the governmental intrusion on the freedom is so compelling as to justify limiting the right. ${ }^{343}$ The means chosen to limit that right must be proportional to the purpose promoted: (1) they must be rationally connected to the objective of the limitation, ${ }^{344}$ (2) they must impair the protected rights as little as possible, ${ }^{345}$ and (3) the effects of the

338. CAN. Const. (Constitution Act, 1982) pt. A (Canadian Charter of Rights and Freedoms), § 1 .

339. Id. $\$ 2$.

340. Id. \$15; see also Colleen Sheppard, Equality in Context: Judicial Approaches in Canada and the United States, 39 U.N.B.L.J. 110, 113 (1990).

341. CAN. CONST. (Constitution Act, 1982) pt. A (Canadian Charter of Rights and Freedoms), $\$ 27$ ("This Charter shall be interpreted in a manner consistent with the preservation and enhancement of the multicultural heritage of Canadians.").

342. [1986] 1 S.C.R. 103, 135-42 (deciding that a statutory presumption that possession of narcotics by defendants means that trafficking by defendant can be inferred violated the presumption of innocence guaranteed by the Canadian Charter of Rights and Freedoms and was unconstitutional because it was not "demonstrably justified in a free and democratic society").

343. Chief Justice Brian Dickson, the author of the majority opinion in Keegstra, noted in Oakes that this

standard must be high in order to ensure that objectives which are trivial or discordant with the principles integral to a free and democratic society do not gain section 1 protection. It is necessary, at a minimum, that an objective relate to concerns which are pressing and substantial in a free and democratic society before it can be characterized as sufficiently important.

Id. at 138 .

344. Id. at 139.

345. This has obvious similarities with the American "least restrictive alternative" standard, although there are some differences. Regina v. Edward Books and Art, Ltd. [1986] 2 S.C.R. 713, 772 (using language that the restriction on the individual freedom must impair freedom as little 
state regulation on individual liberty must be proportional to the governmental objective. ${ }^{346}$

The Canadian Supreme Court applied the Oakes test in a number of hate speech cases, most notably Regina v. Keegstra, ${ }^{347}$ a case decided before R.A.V. that upheld a criminal prosecution for hate speech. In Keegstra, the defendant, James Keegstra, taught social studies in an Alberta high school. He argued to his students that history could be understood through analyzing the "International Jewish Conspiracy," which he claimed has been responsible for many of the world's problems. Keegstra was dismissed as a teacher and later criminally prosecuted for promoting racial hatred. The Canadian Supreme Court found that Keegstra's Section 2(b) rights had been implicated, ${ }^{348}$ and therefore it had to decide whether the limitation on those rights could be justified under the Oakes test.

The Canadian Court generally agreed that the purpose or objective of the limitation on freedom of speech was a "pressing and substantial concern in a free and democratic society." ${ }^{349}$ Chief Justice Brian Dickson, writing for the Court, noted that hate crimes worsened victims' sense of self and decreased victimized groups' participation in public life. ${ }^{350}$ The Court's disagreement was over whether the restriction on speech was proportional to the objective. The majority felt it was proportional because of the minimal value of hate speech expression, ${ }^{351}$ while the dissent was concerned that prosecuting those convicted of hate speech may actually make them martyrs and increase the frequency of hate speech. ${ }^{352}$

as reasonably possible); Pamela A. Chapman, The Politics of Judging: Section 1 of the Charter of Rights and Freedoms, 24 OsGOODE Hall L.J. 867, 886, 889-90 (1986) (analyzing the relationship between Edward Books, Oakes and the least restrictive alternative test).

346. Oakes, 1 S.C.R. at 139. This element of the Oakes test first appeared in Justice Dickson's opinion in Regina v. Big M Drug Mart [1985] 1 S.C.R. 295. This element of the Oakes analysis necessarily "will vary depending on the circumstances," Oakes, 1 S.C.R. at 138, because "courts will be required to balance the interests of society with those of individuals and groups." Id. at $139-40$.

347. [1990] 3 S.C.R. 697.

348. Id. at 725-34; id. at 826-42 (McLachlin, J., dissenting). Chief Justice Dickson noted that:

Apart from rare cases where expression is communicated in a physically violent form, the

Court [has] viewed the fundamental nature of the freedom of expression as ensuring that

"if the activity conveys or attempts to convey a meaning, it has expressive content and prima facie falls within the scope of the guarantee."

Id. at 729 (quoting Irwin Toy, Ltd. v. Quebec [1989] 1 S.C.R. 927, 969).

349. Oakes, 1 S.C.R. at 138-39.

350. Keegstra, 3 S.C.R. at 701-08.

351. Id. at 759-86.

352. Id. at 852-53 (McLachlin, J., dissenting). 
1. The Virtues of Looking to Canadian Constitutional Law on Hate Speech

What could the R.A.V. Court have learned from Keegstra? The Canadian Court had comparative advantages because it had addressed the issue earlier, made binding decisions, and observed how these decisions had operated in the real world. The contextual differences between hate speech in the Canadian context and hate speech in the American context are not so great for the U.S. Supreme Court not to be able to learn anything. First of all, the U.S. Supreme Court could have studied Keegstra for its Oakes proportionality test, and considered adopting that test and applying it in American hate speech cases. The Canadian Court faced the same problem that the U.S. Court should have realized it faced: the battle between liberty and equality. American sources were unclear in helping the R.A.V. Court come up with a workable principle; it faced the same issue as the Canadian Court, and therefore it could have adopted the Oakes proportionality test. The Oakes proportionality test would be a helpful test for American constitutional law; it embraces candor and realism, making it an attractive principle and supporting the better solution virtues of refined comparativism.

Also, the R.A.V. Court could have used the Canadian experience to help it gauge some relevant constitutional facts. How has Canadian regulation of hate speech worked? If it has worked very well, then that might make it a stronger argument that in the American context regulation of hate speech is a "compelling end." How have different Canadian regulations worked? Has Canada used other regulations that restrict speech less than the St. Paul regulation? These types of comparative constitutional law questions assist with the means-end examination in the American context. The R.A.V. Court, for example, stated that "St. Paul has sufficient means at its disposal to prevent such [hateful] behavior without adding the First Amendment to the fire. ${ }^{\prime 353}$ Looking at the Canadian experience with hate speech regulation can prove whether or not this is the case-have other Canadian regulations worked? Does St. Paul have "sufficient means" to combat hate speech? The R.A.V. Court, as part of its means-end test, may have been concerned, as the dissent in Keegstra was, that restricting hate speech will increase its prevalence because it will make martyrs of those prosecuted. Looking at the Canadian experience to see whether this is so can be helpful evidence to discover if this worry about martyrdom has mate-

353. R.A.V. v. St. Paul, 505 U.S. 377, 396 (1992).

354. Id. 
rialized. ${ }^{355}$ The Canadian experience, and the accessibility of that experience to the American judge, would have helped overcome the type of institutional limitations facing judges in hate speech cases. Judges in hate speech cases inquire, for example, how hate speech affects minority communities. Because of the sociolegal changes discussed earlier, ${ }^{356}$ however, this type of inquiry has become harder and harder for a judge to perform. A court needs to rely on other sources to complete this inquiry-perhaps lower courts, perhaps policymaking bodies, but also comparative constitutional experience.

More fundamentally, an analysis of the Keegstra case, especially after comparing it to the U.S. Supreme Court's decision in R.A.V., helps illuminate some of the assumptions behind the American reasoning. The R.A.V. Court, or a court later deciding whether or not to apply R.A.V., could use Keegstra to help it see the unstated assumptions of American jurisprudence on hate speech. ${ }^{357}$ The American opinion paints no private actor as being as threatening as the state. The R.A.V. Court insists that the "danger of [state] censorship" ${ }^{\$ 38}$ is so great that any regulation focusing on the content of communication will be viewed with great suspicion. Justice White argues that the dangerous state is reason enough for the stringent overbreadth doctrine. ${ }^{359}$ In R.A.V., the majority argued that the ability of "the Government... [to] drive certain ideas or viewpoints from the marketplace ${ }^{\$ 36}$ could eventually lead to a state without civil liberties. By contrast, the Canadian opinion views the state as pursuing, albeit in a less than

355. The Canadian Supreme Court itself used comparative constitutional law to help it find relevant constitutional facts. The dissent referred to the experience in pre-Nazi Germany that, the dissent argued, featured an increase in hate speech following the criminalization of various types of speech. Keegstra, 3 S.C.R. at 854 (McLachlin, J., dissenting) (discussing the regulation of various types of speech in pre-Hitler Germany). The court-appointed expert could use this comparative constitutional law data in the American context. Although the relationship between the criminalization of certain behavior and its frequency is complex, and translating foreign data about this even more complex, a judge could glean some insights from data through the use of experts.

356. Supra text accompanying notes $147-150$.

357. The assumptions behind R.A.V. would obviously not have been available for the R.A.V. Court to analyze, but these assumptions that I am indicating were present in R.A.V. are also present in all of the cases relevant to R.A.V. Thus, the R.A.V. Court could have looked to these precedents and their assumptions and to Keegstra and its assumptions to help it determine how to decide the case.

358. R.A.V., 505 U.S. at 395 (quoting Leathers v. Medlock, 499 U.S. 439, 448 (1991)).

359. Id. at 411 ("'The possible harm to society in permitting some unprotected speech to go unpunished is outweighed by the possibility that protected speech of others may be muted' [by the state]." (quoting Broadrick v. Oklahoma, 413 U.S. 601, 612 (1973))).

360. R.A.V., 505 U.S. at 436. 
perfect fashion, the public interest. ${ }^{361}$ Is this difference in attitudes towards the state justified? Is the skeptical attitude towards the Orwellian state manifested in R.A.V. as justified in an age of mass media scrutiny-or does the pervasiveness of the administrative state make the American government even more dangerous? ${ }^{362}$ This would have certainly been a helpful subject of inquiry for an American court, one that would be helpfully illuminated by an analysis of the Canadian opinion.

Second, R.A.V. paints the hateful speaker as harmless and idealistic, describing the hate speech punished by the St. Paul ordinance as simply discussion of "disfavored subjects" ${ }^{363}$ and as a "particular idea." 364 Those who utter hate speech are simply the constitutional representatives for all citizens who want to engage in speech or expressive activities. By contrast, Keegstra paints hate speech in a much less flattering light. ${ }^{365}$ Third, R.A.V. barely discusses the victim or victims of hate speech. Justice Scalia only mentions, at the very end of his opinion, the Court's "belief that burning a cross in someone's front yard is reprehensible." ${ }^{\$ 66}$ The interest in promoting hate speech laws, to the extent the R.A.V. Court recognizes one, is purely private. $^{367}$ Chief Justice Dickson's opinion for the Keegstra majority, however, begins its analysis by mentioning why the regulation of hate speech is important, and by mentioning certain public interests such as equal participation in public life and democracy. ${ }^{368}$ Finally, the R.A.V. Court views hate speech regulation as an extension of the subversive advocacy cases, and as an example of a procedural, Schumpeterean model of democracy. If the state silences anyone, it distorts the processes of democracy, the

361. Hate speech legislation, directed by the state, is aimed at ensuring equal citizenship and the participation of all in public life. See Charles Taylor, Can Canada Survive the Charter?, 30 AlberTA L. REV. 427, 429 (1992) (noting that Canadians are happy with their social programs, and that hate speech in particular ensures attention to the "collective provision").

362. Perhaps American history, as exemplified by the McCarthy era and the Alien and Sedition Acts, serves as proof of the possibility of state censorship of all forms of speech. Canada, however, has its own history of censorship. THOMAS R. BERGER, FRAGILE FREEDOMS: HumAN RIGHTS AND DISSENT IN CANADA (1981).

363. R.A.V., 505 U.S. at 391.

364. Id. at 393.

365. The Keegstra opinion includes a discussion of the Nazi experience with hate. Regina v. Keegstra [1990] 3 S.C.R. 697, 770.

366. R.A.V, 505 U.S. at 396. Justices that disagreed with Scalia's opinion did paint a differing picture of hate speech. Id. at 402 (White, J., concurring) (arguing that cross burning is an expression of violence and of racism).

367. Indeed, even American scholarship supporting hate speech regulation seems to conceptualize the interests furthered by hate speech laws as private, individual freedoms rather than as public interests. Supra note 336.

368. Keegstra, 3 S.C.R. at 705-09. 
"marketplace of ideas," and the competition of ideas. ${ }^{369}$ By contrast, the Keegstra Court views democracy as substantive, and values such as equality and the dignity of every human being as central to the democratic project. $^{370}$

The Keegstra Court also seems willing to grapple with the real-world consequences of its decision in a way that the R.A.V. Court may not have realized it was failing to do. The Keegstra Court rejected the clear and present danger test ${ }^{371}$ of American constitutional law, ${ }^{372}$ because it recognized that serious harms might not be so identifiable immediately after harmful speech. Harmful speech may have subtle effects that rely on fear and ignorance over time that may be hard to detect, but it may eventually cause more harm than the harm the clear and present danger test attempts to prevent. Also, the Brandenburg v. Ohio ${ }^{373}$ requirement that violence must be imminent to be proscribed may be objectionable. The Keegstra opinion recognizes that different listeners respond to speech in different ways, and that the type of violent, sudden response that Brandenburg focuses on may privilege a particular type of macho reaction to speech without a concern for a more serious yet subtle imminent harm.

The Court could have benefited from studying Keegstra, either before or after writing its R.A.V. opinion, if for no other reason than that it might help the Justices realize all of the unstated assumptions they are making, and make them question whether those assumptions are justified. A later U.S. Supreme Court relying on R.A.V. could also benefit by studying Keegstra, because it will have an even greater ability to see unstated assumptions by comparing the opinion in R.A.V. with that in Keegstra. Seeing these unstated assumptions may have led to a change in legal analysis, or it simply may have led to a more realistic use of judicial rhetoric; either way, it would be preferable to the opinion that does not use comparative constitutional law. The Keegstra method of recognizing the clash between liberty and equality and its balancing test have some of the virtues of

369. Joseph A. SCHUMPeTER, CAPITAlism, SOCIALiSM AND DEMOCRACY 269 (3d ed. 1950) (stating that constitutional democracy is the "institutional arrangement for arriving at political decision in which individuals acquire the power to decide by means of a competitive struggle for the people's vote").

370. Thus, perhaps Canadian constitutional democracy is closer to the German version of a "militant democracy." BVerfGE 5, 85 (139) (F.R.G.), translated in KOMMERS, supra note 9, at 223; see also Gregory H. Fox \& Georg Nolte, Intolerant Democracies, 36 HARV. INT'L L.J. 1 (1995).

371. Schenck v. United States, 249 U.S. 47, 52 (1919) ("The question in every case is whether the words used are used in such circumstances and are of such a nature as to create a clear and present danger that they will bring about the substantive evils that Congress has a right to prevent.").

372. Keegstra, 3 S.C.R. at 740-44.

373. 395 U.S. 444 (1969). 
candor and frankness that have long been noted by American scholars in conjunction with their praise of explicit constitutional balancing. ${ }^{374}$

\section{Criticisms of Looking to Canadian Constitutional Law on Hate Speech}

The critic of refined comparativism may have several problems with using comparative constitutional law in the R.A.V. case. First, one could argue that the Oakes proportionality test already exists in American constitutional law. While there are some cases that do generally deal with proportionality, ${ }^{375}$ however, these cases do not deal with proportionality in the context of hate speech as the Canadian cases do. The Canadian cases address the concern of whether the regulation of hate speech may be excessive compared to its purpose, looking at equality, liberty, and a number of other factors that the American opinions, to the extent they even do use proportionality, ignore. Second, the contextual differences between Canada and the United States are real but not fatal. Section 15 of the Canadian Charter is much broader in scope and has wider substantive protections and more prohibited grounds of discrimination than the Fourteenth Amendment. This could have alerted the U.S. Supreme Court not to borrow all aspects of Canadian hate speech cases, but it would not defeat the entire enterprise of constitutional borrowing. No matter how broad the protection for equality concerns, Canada found a way to balance equality and liberty - how exactly it did that is one of the details the U.S.

374. E.g., Thomas I. Emerson, Toward a General Theory of the First Amendment, 72 YALE L.J. 877, 912-16 (1963); Laurent B. Frantz, The First Amendment in the Balance, 71 YALE L.J. 1424 (1962); Laurent B. Frantz, Is the First Amendment Law?-A Reply to Professor Mendelson, 51 CAL. L. REV. 729 (1963); Charles Fried, Two Concepts of Interests: Some Reflections on the Supreme Court's Balancing Test, 76 HARV. L. REV. 755 (1963); Alexander Meiklejohn, The First Amendment Is an Absolute, 1961 SuP. CT. REV. 245, 255-57; Wallace Mendelson, The First Amendment and the Judicial Process: A Reply to Mr. Frantz, 17 VAND. L. REV. 479 (1964); Wallace Mendelson, On the Meaning of the First Amendment: Absolutes in the Balance, 50 CAL. L. REV. 821 (1962); Charles A. Reich, Mr. Justice Black and the Living Constitution, 76 HARV. L. REV. 673, 737-44 (1963). See generally T. Alexander Aleinikoff, Constitutional Law in the Age of Balancing, 96 YALE L.J. 943, 972 (1987).

375. E.g., BMW v. Gore, 517 U.S. 559 (1996); Dolan v. City of Tigard, 512 U.S. 374 (1994). Balancing approaches roughly similar to proportionality have appeared in dormant commerce clause cases. E.g., Pike v. Bruce Church, Inc., 397 U.S. 137, 142 (1970) (finding that a statute is acceptable "unless the burden imposed ... is clearly excessive in relation to the putative local benefits. If a legitimate local purpose is found, then the question becomes one of degree."). In First Amendment jurisprudence, the Court in upholding the Smith Act, 18 U.S.C. $§ 11$ (1994), did use a form of balancing that resembles proportionality analysis. Dennis v. United States, 341 U.S. 494 (1951). 
Supreme Court could have addressed when it decided how much of the Canadian analysis it wanted to incorporate.

Canadian courts do play a different role in the Canadian constitutional system than American courts play in the American constitutional system. The Non-Obstante Clause ${ }^{376}$ and other factors may mean that Canadian courts have more authority to conduct balancing tests. ${ }^{377}$ The United States, by contrast, may require "rules" rather than "standards" because it is a large, diverse republic with lower courts that rely on the Supreme Court for guidance, and because there is a substantial history of skepticism of judicial discretion. Again, however, this simply may limit the scope of the constitutional borrowing rather than defeat the entire enterprise. Canadian courts may have more authority to conduct balancing tests, but American courts already use balancing all of the time-this may simply mean that American courts should conduct more narrow Oakes proportionality tests.

Similarly, perhaps differences in the roles of other legal institutional actors may caution against using Keegstra in American hate speech cases. As Mark Tushnet noted in his Yale Law Journal article on comparative constitutional borrowing, there are substantial differences in the structure of prosecutorial authority in Canada and the United States. ${ }^{379}$ Prosecution decisions are made by a more centralized authority in Canada than in the United States and therefore there is a greater risk in the United States of singling out speech by racial minorities as the only hate speech that should be prosecuted. This claim, however, does not seem particularly persuasive. For one thing, the rise of the mass media means that prosecutorial abuses by local officials in the United States will fairly frequently be publicized and brought to the attention of central authorities and therefore prosecutions might end up being filtered in the same way as they are in Canada. At a more basic level, this criticism does not affect the above analysis of Keegstra because the data about the potential for abuse-from Canada and from the United States - can be used to shape the exact nature of hate speech regulation allowed in the United States. Canada provides data about the possibility of abuse given centralized prosecution structures, while the American

376. CAN. CONST. (Constitution Act, 1982) pt. A (Canadian Charter of Rights and Freedoms), §33.

377. See, e.g., Patrick Monahan, The Charter, Federalism and the Supreme COURT OF CANADA 30-32, 53-60, 78-79 (1987) (arguing that Canadian courts should conduct balancing tests).

378. Sullivan, supra note 64.

379. Tushnet, supra note 12 , at 1282-85. 
experience might provide alternate data about localized prosecution systems and hate speech regulation.

A critic of using refined comparativism in this case may also worry that Canadian culture has generally favored the mosaic version of multiculturalism while American culture has favored the melting pot version. ${ }^{380}$ In the face of cultural diversity, Canada has favored at least occasional particularism and accommodation. Thus, for Canadian politicians such as Pierre Trudeau, and for Canadian constitutionalists, accommodating Quebec or the increase of immigration meant recognizing cultural difference. By contrast, in the United States, dealing with multiculturalism has meant appealing to the universal rather than to the particular.

These possible differences do not obscure the fact, however, that both countries are sociologically diverse, have internal language differences, and have native populations that have historically been suppressed. ${ }^{381}$ The Canadian mosaic may mean that the stringency of the test adopted into the American context may differ, but it does not mean that the legal principle cannot be borrowed or that the type of constitutional facts the Canadian experience can provide are not relevant. American constitutional law, despite its claims of universality and categorical interpretive techniques, has always incorporated some form of balancing tests in recent times. This supposed distinctive American universalism is therefore more imagined than real. Even without the benefits of refined comparativism in the context of hate speech that result from actual doctrinal borrowing, there are still many benefits to be gained by using refined comparativism, even if this particular-universal contextual difference stands up after examination: The range of background assumptions discussed above can highlight what undergirds even an American constitutional universalism.

\section{B. Europe, Hate Speech, and Refined Comparativism}

Individual countries on the Continent and supranational bodies on the Continent have dealt with hate speech issues. Most famously, in the Irving case in Germany the Constitutional Court held that orders prohibiting the convening of a conference at which the "revisionist historian" David Irving was to speak did not violate Article 5(1) of the Basic Law. ${ }^{382}$ Article

380. See, e.g., Lorraine Weinrib, Canada's Charter: Rights Protection in the Cultural Mosaic, 4 CARDOZO J. INT'L \& COMP. L. 395 (1996).

381. For a more extensive analysis of the similarities between the United States and Canada and its implications for constitutional law, see Alan F. Westin, The United States Bill of Rights and the Canadian Charter: A Socio-Political Analysis, in THE U.S. BILl OF RIGHTS AND THE CANADIAN CHARTER OF RigHTS AND FREEDOMS 27 (William McKercher ed., 1983).

382. Judgment of Apr. 23, 1994, Bundesverfassungsgerichts (BVerfGE), 1994 N.J.W. 1779. 
5(1) guarantees freedom of expression in the following terms: "Everyone shall have the right freely to express and disseminate his opinion by speech, writing and pictures and freely to inform himself from generally accessible sources. Freedom of the press and freedom of reporting by means of broadcasting and films are guaranteed. There shall be no censorship." ${ }^{383}$ The boundaries are limited by paragraph two, which states that "these rights are limited by the provision of the general laws, the provisions of law for the protection of youth, and the right to inviolability of personal dignity." 384 Germany's experience with the role of personal dignity in hate speech cases could have been helpful for the R.A.V. Court in its search for a workable principle. Also, the European Convention lists eleven limitations on the freedom of expression under Article 10(2). ${ }^{385}$ Its justifications for these limitations, and how these limitations have worked in the courts and in society, all could have been helpful subjects of study for the R.A.V. Court.

\section{CRITICISMS}

\section{A. Normative Objections}

\section{Completely Theorized Constitution}

Refined comparativism is a contingent strategy of interpretationcontingent on the recognition of ambiguity in the domestic constitutional sources used to resolve a given constitutional case. If hard cases were relatively rare, then refined comparativism would not be used as much. A more dramatic criticism of refined comparativism, however, would argue that American constitutional sources do provide all of the answers in constitutional cases, even hard cases. ${ }^{386}$ The Calabresi opinion in United States $v$. Then ${ }^{387}$ that advocated the borrowing of the suspensive veto from

383. Grundgesetz [GG] [Constitution] art. 5(1) (F.R.G.)

384. Id. art. 10(2), art. 5(2).

385. The EuROPEAN CONVENTION ON Human Rights 426 (Francis G. Jacobs \& Robin C.A. White eds., 2d ed. 1996). For each of the eleven exceptions in Article 10(2), there have been a number of cases that use interesting principles to balance expression and other interests. The experience of Europe with these eleven limitations could certainly have helped the R.A.V. Court.

386. Consider this the idea of the "completely theorized" Constitution, as opposed to Cass Sunstein's idea of "incompletely theorized agreements," CASS R. SUNSTEIN, LEGAL REASONING AND Political CONFlict 35 (1996), and the partial Constitution. CASS R. Sunstein, The PARTIAL CONSTITUTION (1993).

387. 56 F.3d 464, 466-69 (2d Cir. 1995) (Calabresi, J., concurring). 
Continental constitutional law ${ }^{388}$ might be criticized, for example, by reference to Calabresi's opinion in Quill v. Vacco, ${ }^{389}$ the right to die case. Once Calabresi undertook a more extensive analysis of the domestic constitutional sources in that case, he found an "answer" from American sources and did not have to look abroad for a constitutional answer. The constitutional theory that believes in a "completely theorized constitution," whether this totalism is drawn from text, ${ }^{390}$ history, ${ }^{391}$ structure, ${ }^{392}$ or national experience, ${ }^{393}$ may have comparatively little use for refined comparativism.

Even within the completely theorized constitution, however, there is room for the use of comparative constitutional law. On one hand, of course, in their role as advice givers ${ }^{394}$ who use dicta to achieve various ends, judges can cite to comparative constitutional law. More importantly, however, even the completely theorized constitution will sometimes run into ambiguity. A completely theorized account of federalism for example, may find that our constitutional law clearly supports a "dual federalism" ${ }^{\text {"395 }}$ understanding of our constitutional system. The totalist may argue, therefore, that there is no need to look abroad for answers. But the completely theorized constitution may not lead to a series of principles that help judges deal with cases. Dual federalism, viewed through the lens of

\footnotetext{
388. Id. at $468-89$.

389. 80 F.3d 716, 731 (2d Cir. 1996).

390. E.g., Akhil Reed Amar, Intratextualism, 112 HARV. L. REV. 747 (1999).

391. E.g., Antonin Scalia, Originalism: The Lesser Evil, 57 U. CIN. L. REV. 849 (1989).

392. E.g., CHARLES L. BLACK, JR., STRUCTURE AND RELATIONSHIP IN CONSTITUTIONAL LAW (1969)
}

393. Bruce Ackerman, for example, has written:

America is a world power, but does it have the strength to understand itself? Is it content, even now, to remain an intellectual colony, borrowing European categories to decode the meaning of its national ... identity?

....

To discover the Constitution, we must approach it without the assistance of guides imported from another time and place. Neither Aristotle nor Cicero, Montesquieu nor Locke, Harrington nor Hume, Kant nor Weber will provide the key. Americans have borrowed much from such thinkers, but they have also built a genuinely distinctive pattern of constitutional thought and practice.

ACKERMAN, supra note 175, at 3. But see Richards, supra note 174, at 584-86. Ackerman has elsewhere criticized the "emphatic provincialism" of American constitutional theory, Ackerman, supra note 3 , at 773 , and argued that comparative constitutional law can provide "a formidable fund of experience." Id. at 775.

394. Katyal, supra note 63.

395. E.g., Heath v. Alabama, 474 U.S. 82 (1985) (protecting states' power to enforce their own criminal laws); Abbate v. United States, 359 U.S. 187 (1959) (discussing the efficiency of federal law enforcement); Bartkus v. Illinois, 359 U.S. 121 (1959), reh'g denied, 360 U.S. 907 (1959) (attempting to preserve the balance of prosecutorial powers between federal and state governments); United States v. Lanza, 260 U.S. 377 (1922) (protecting the government's power to fully prosecute an offense that violates both federal and state law). 
purely American sources of constitutional meaning, can lead to a number of different judicial principles. However, combining these American sources of constitutional meaning with the additional data points provided by comparative constitutional law can help a judge see how different principles actually work.

More fundamentally, however, it is rather implausible to argue for the completely theorized constitution. The originalist account for complete theorization must consider the Founders' limited ability to foresee the future, ${ }^{396}$ and the inherently incomplete nature of their political compromises that led to the Constitution. ${ }^{397}$ This political compromise was partly attributable to the circumstances in which the Founders operatedin a situation of crisis with serious time constraints. ${ }^{398}$ The textualist must also account for the inevitable generality of the constitutional text, whether read in clause-bound fashion ${ }^{399}$ or intratextually. ${ }^{400}$

\section{Cultural Particularism}

The particularist may argue that American constitutional experience has been distinctly American, and to use comparative constitutional sources violates the constitutive nature of American constitutional law. ${ }^{401}$

396. James Madison, speaking in the first Congress in opposing the creation of the national bank, stated that: "It is not pretended that every insertion or omission in the Constitution is the effect of systematic attention. This is not the character of any human work, particularly the work of a body of men.” 2 ANNALS OF CONG. 1899 (1791) (quoting James Madison).

397. Hylton v. United States, 3 U.S. (3 Dall.) 171, 177-78 (1796) ("The constitution has been considered as an accommodating system; it was the effect of mutual sacrifices and concessions; it was the work of compromise."). Justice Joseph Story concluded that the Constitution was therefore incomplete, and "no uniform rule of interpretation can be applied to it ... [it] positively demand[s] ... many modifications in its actual application to particular clauses." Prigg v. Pennsylvania, 41 U.S. (16 Pet.) 539, 610 (1842).

398. Jon Elster, Forces and Mechanisms in the Constitution-Making Process, 45 DUKE L.J. 364, 370-71 (1995). Recent foreign experiences drafting constitutions confirms the time-bound nature of the practice. E.g., A.E. Dick Howard, The Indeterminacy of Constitutions, 31 WAKE FOREST L. REV. 383, 396 (calling the Polish "Little Constitution" of 1992 a "compromise" constitution); Howard \& Fontana, supra note 18 (discussing the time pressures facing constitution drafters in central and eastern Europe after 1989).

399. Cf. ELY, supra note 89, at 11-41 (criticizing "clause-bound" textual constitutional analysis).

400. Amar, supra note 390.

401. E.g., William P. Alford, On the Limits of "Grand Theory" in Comparative Law, 61 WASH. L. REV. 945, 946-47 (1986) (arguing that "assumptions and values... shared [by society]" constitute our law and therefore make legal borrowing undesirable); George P. Fletcher, Constitutional Identity, 14 CARDOZO L. REV. 737, 739 (1993) (arguing that hard constitutional cases reflect an "element of yearning" in a culture and therefore it is problematic to borrow legal solutions); Frederick Schauer, Free Speech and the Cultural Contingency of 
Refined comparativism, however, does not use comparative constitutional law in such a radical way as to displace the centrality of American sources. It creates a workable judicial principle by looking at American sources, deciding that theses sources lead to a particular concept, and affixing a particular comparative conception to that concept. The institutions that American courts are borrowing from are not that different from our courts - they are engaged in some of the same basic tasks. Constitutional courts around the world are all reflective institutions. In a very real sense, they represent political man writ large writing and thinking about where to draw the line between the liberties of the individual and the power of the state. The cultural linkages between these constitutional courts and our courts are even more obvious now than they have been in the past. Whether or not refined comparativism would have been justifiable eighty years ago, the constitutive nature of constitutional identity sketched out earlier ${ }^{402}$ makes the constitutional law of other countries part of our cultural fabric as well. Because a growing number of citizens come from parts of the world whose traditions are not reflected in traditional American constitutional law, refined comparativism is a strategy of inclusion and of giving expression to our culture through the use of comparative constitutional law.

\section{B. Pragmatic Objections}

\section{Pragmatic Particularism}

Comparative law has long featured a debate about the degree to which the transplantation of legal rules from one legal system to another will work. ${ }^{403}$ Most famously, Otto Kahn-Freund employed Montesquieu's view ${ }^{404}$

Constitutional Categories, 14 CARDOZO L. REV. 865, 877 (1993) (noting the centrality of "cultural experience and cultural history" in constitutional law).

402. Supra text accompanying notes 161-162.

403. E.g., Oscar G. Chase, Legal Processes and National Culture, 5 CARDOZO J. INT'L \& COMP. L. 1, 1-2 (1997). Oscar Chase argues that

the relationship between national culture and dispute resolution processes ... takes on new urgency with the acceleration of globalization.... [I]nstitutional differences ... implicate and reflect different and deeply held attitudes about the appropriate relationship between individuals and authority. [For example, t]he German system ... reflects a willingness to accept structures of authority that are inimical to the more individualistic Americans.

Id.; see also John H. Langbein, Cultural Chauvinism in Comparative Law, 5 CARDOZO J. INT'L \& COMP. L. 41, 41 (1997) (arguing that Chase wrongly bases his views on "ethnic stereotypes").

404. 1 Charles De SeCONDAT MONTESQuieu, De L'ESPRIT DES LOIS ch. 3 (Geneva, Barrillot \& Fils 1748) ("[The political and civil laws of each nation] should be so closely tailored to the people for whom they are made, that it would be pure chance [un grand hazard] if the laws of one nation could meet the needs of another."). 
that law will not be easily transferable from country to country. ${ }^{405}$ Alan Watson argues that Kahn-Freund misunderstands the transplantability of legal rules. ${ }^{406}$ In the context of refined comparativism, however, this debate about the workability of legal transplants does not appear as relevant. ${ }^{407}$ First of all, refined comparativism essentially involves courts making very broad and general rules, whose specific content will be filled in by subsequent cases coming from the American social context. ${ }^{408}$ Kahn-Freund and Watson, as did many others, viewed legal transplants primarily in terms of the transplant of legislation, ignoring Roscoe Pound's admonishing instruction that "a fruitful comparative law ... has to do much more than set side by side sections of codes or . . legislation." ${ }^{409}$

Also, it must be kept in mind that refined comparativism does not contemplate the type of radical, wholesale transplants that Kahn-Freund and Watson address. A refined comparativist judge only uses comparative constitutional law after deciding that contextual factors and cultural differences will not impinge on the transferability of the constitutional principle or fact, assisted very often by a comparative law expert. If the refined comparativist judge decides to use comparative constitutional law but still remains concerned about the transferability of the constitutional principle or fact, the judge has the power over precedent to mitigate possible problems - the judge can refuse to adopt wholesale the precedents of another country and can just adopt one particular case, and in the domestic context can decide that the case using comparative constitutional law should not have precedential effect for a certain period of time, or will receive less precedential power. ${ }^{410}$ There can be refined comparativist "maximalists" and refined comparative "minimalists." Furthermore, the impact of differing social contexts on the transferability of legal rules has taken on a different dynamic given social conditions in the early twentyfirst century. The United States is relatively heterogeneous, and the geographic space affected by a refined comparativist decision may be more

405. Otto Kahn-Freund, On Uses and Misuses of Comparative Law, 37 MoD. L. REV. 1, 7 (1974). These concerns about the workability of foreign legal rules might be heightened in a postRealist world, in which almost everyone agrees that legal texts are unclear and require reference to extratextual sources, extratextual sources that are inherently culturally contingent.

406. WATSON, supra note 4, at 95-96.

407. There might be other "intertextual" sources that would be more relevant and less subject to the problems of particularism. These sources, such as state constitutions, may be a better source of comparative insight, but often they too will not yield a clear answer, thus still making the case before a court a "hard" case.

408. When a court faces a case that involves much more specific and idiosyncratic action, it should not use comparative constitutional law. Supra text accompanying note 96.

409. Roscoe Pound, Comparative Law in Space and Time, 4 AM. J. COMP. L. 70, 75 (1955).

410. Supra note 90 . 
culturally similar to a part of another country than it is to another part of the United States. It is precisely this fact that makes lower courts the better laboratories for trying refined comparativist experiments-for using comparative constitutional law when its benefits may not be as clear.

\section{Judicial Application}

Another criticism of refined comparativism would focus on the ability of judges to play the role visualized by refined comparativism. American legal education does not provide judges with the type of comparative constitutional training that they need. Furthermore, non-English speaking countries must have their legal materials translated, ${ }^{411}$ most judges speak only English, ${ }^{412}$ and translation always involves interpretation. This may result in an Anglophile refined comparativism, ${ }^{413}$ with the best example

411. The issues raised by legal translation are rarely discussed, with some notable exceptions. E.g., Williams v. Arndt, 626 F. Supp. 571, 577 (D. Mass. 1985) (comparing the "mere clerical function" of a computer programmer writing code to someone translating "any foreign language"); Sacco, supra note 4, at 20 ("The complexity of the problems involved in legal translation makes the carelessness with which they are approached seem incredible."); Peter W. Schroth, Legal Translation, 34 AM. J. COMP. L. 47, 47 (Supp. 1986) ("Despite its great practical importance, legal translation is little discussed; despite its difficulty, it is frequently assigned to translators without legal training. Plainly both the importance and the difficulty are commonly underestimated.").

412. John G. Sprankling \& George R. Lanyi, Pleading and Proof of Foreign Law in American Courts, 19 StAn. J. InT'L L. 3, 35 (1983); see also SuSAN BERK-SELIGSON, THE BiLinguAL COURTROOM: COURT INTERPRETERS IN THE JUdiCIAL PROCESS 17 (1990). There are plenty of examples of a judge using his or her knowledge of a foreign language to translate relevant materials from a foreign language by him or herself. E.g., In re The Prahova, 38 F. Supp. 418 (S.D. Cal. 1941).

413. This is particularly true when one considers what materials law libraries are likely to hold-primarily the materials of wealthy countries, who will disproportionately speak English and have ample money to publish their judicial opinions. Comparative law scholarship has reflected this ethnocentrism. For example, Japanese legal studies receive relatively little attention in comparative law. As Frank K. Upham has discovered:

In the forty-six years from 1950 to the middle of 1996, the AJCL [American Journal of Comparative Law] published approximately 1450 book reviews. Sixty percent of reviewed books were written in English and the rest in other European languages, including thirtyfive percent in German or French. One book was in a non-European language, Chinese.... Of over 1100 articles during this period, twenty-six or 2.32 percent concerned Japan. There were twenty-seven about China. In the same period there were ninety-one and seventy-four articles about Germany and France, respectively. Europe as a whole occupied 41.12 percent versus 8.67 percent for Asia, including South Asia ....

Frank K. Upham, The Place of Japanese Legal Studies in American Comparative Law, 1997 UTAH L. REV. 639, 641.

This may be changing now that publishers like Kluwer, Nijhof, Oceana, Butterworths, and Mohr have published comparative constitutional law materials. There has also been a proliferation of American scholarly publications on comparative and international law. Cf. Roger C. Cramton, "The Most Remarkable Institution": The American Law Review, 36 J. LEGAL EDUC. 1, 8 (1986). The Internet, Lexis, and Westlaw provide instant access to foreign materials translated 
being Bowers v. Hardwick, ${ }^{414}$ in which the Court for no good reason focused only on English language materials in performing its comparative constitutional law analysis. ${ }^{415}$ In short, even if refined comparativism is a good idea, can judges pull it off? $?^{416}$

The first and most important thing to remember about refined comparativism is the role of experts. ${ }^{417}$ Judges have already been immersing themselves in foreign law as the American economy has globalized, ${ }^{418}$ and have done so on many occasions with the assistance of foreign law experts. ${ }^{419}$ These foreign law experts should have the ability to both speak the language of the host country and should have some background or experience with that country's legal system. Translation, as Lawrence Lessig has noted, ${ }^{420}$ involves both familiarity and equivalence in meaning.

into English, and allow judges and scholars to more easily communicate with their foreign counterparts. M.D. Kirby, The Role of the Judge in Advancing Human Rights by Reference to International Human Rights Norms, 62 AUSTRALIAN L.J. 514, 516 (noting the increasing ability of courts to look to foreign sources with the improvement of contemporary technology).

414. 478 U.S. 186 (1986).

415. This is reminiscent of Justice Black's argument that there is no reason, in looking to what rights were incorporated against the states after the Civil War, to focus only on Englishspeaking countries. Supra note 240.

416. I take no position about the impact refined comparativism would have in general on American constitutional jurisprudence. It is not clear whether borrowing from the constitutional law of other countries would have any effect on the ideological position of American constitutional law, or whether it would move it to the left or to the right. Because this is a method Article-arguing for a particular interpretive technique-I consider the effect on outcomes, as long as the outcomes will be reasonable, outside the scope of this Article. For general discussions of the need to consider systemic consequences when evaluating questions of interpretive method in constitutional law, see Richard H. Fallon, Jr., How to Choose a Constitutional Theory, 87 CAL. L. REV. 535 (1999); and Cass R. Sunstein, Must Formalism Be Defended Empirically?, 66 U. CHI. L. REV. 636 (1999).

417. Add to this the role of the litigants. Because refined comparativism is an idea for the federal courts, and one that will be more relevant for federal appellate courts, litigants appearing before the court will disproportionately be resource-heavy and have the ability to hire translators and employ their own experts-if they do not speak foreign languages themselves. Those being represented by lawyers with fewer research resources would be assisted by the professionalization of comparative constitutional law that I addressed earlier. Cf. Robel, supra note 90, at 946-55 (discussing the impact of unpublished opinions on the research abilities of less well-funded parties to litigation); supra text accompanying notes 105-108.

418. See generally David S. Clark, The Use of Comparative Law by American Courts (I), 42 AM. J. COMP. L. 23, 40 (Supp. 1994) (cataloging the judicial use of comparative materials in international law, international civil procedure, service of process of foreign defendants, civil discovery of evidence in foreign countries, choice of foreign law in civil cases, enforcement of foreign country civil judgments, and criminal proceedings). There are many areas of American law that rely on American judicial analysis of foreign law. E.g., United States v. Gecas, 120 F.3d 1419, 1424-27 (11th Cir. 1997) (analyzing foreign law to determine the possibility of foreign prosecution after the deportation of a litigation party); United States v. Balsys, 918 F. Supp. 588, 592-97 (E.D.N.Y. 1996), rev'd, 524 U.S. 666 (1998) (same).

419. Supra note 122.

420. Lessig, supra note 190. 
Lessig defines familiarity as "develop[ing] modes of thinking that reconnect [one] ... with the dynamic field of words, modes of thinking that will allow them to explore meaning associations within a word and making connections created by words in a specific context." ${ }^{\text {"21 }}$ Moreover, the skilled comparativist must be able to analyze comparative constitutional law within the context of general institutional practices. One of the key contributions of translation theory in the 1980s was "the discovery of the importance of first establishing what norms govern translation behavior before analyzing specific translations," process is governed by norms." 423

The judge comparing legal systems is performing the task of comparison and analogy at the heart of legal reasoning. ${ }^{424}$ With the assistance of an expert (preferably one schooled in the language, culture, and law of the foreign country), or even without one, this process of comparison and analogical reasoning is nothing new to the judge. The judge of the future, and the lawyer of today, has practiced law or taught law in the era of globalization, when a lawyer must be familiar with some aspects of foreign law. ${ }^{425}$ The judge has practiced the art of comparing the laws of different jurisdictions on many other occasions. Judges interpret statutes by looking to the laws of many different states, ${ }^{426}$ have to apply foreign law in many

421. Id. at 1196 (quoting Rainer Schulte \& John Biguenet, Introduction to THEORIES OF TRANSLATION (Rainer Schulte \& John Biguenet eds., 1992)).

422. EDWIN GENTZLER, CONTEMPORARY TRANSLATION THEORIES 136 (1993).

423. Id.

424. Cf. Vivian Grosswald Curran, Cultural Immersion, Difference and Categories in U.S. Comparative Law, 46 AM. J. COMP. L. 43 (1998). Thus, many of the criticisms of the proposals by those like Posner that judges attempt to use social science do not apply. With the benefit of translation, technological advancement, and experts, refined comparativist judges do not face the extent of problems that social science judges do. For a discussion of the limitations facing judges attempting to perform nonlegal analysis, see, for example, Scott Brewer, Scientific Expert Testimony and Intellectual Due Process, 107 YALE L.J. 1535 (1998). Posner, the paradigmatic example of an interdisciplinary constitutional theorist, makes several errors in his interdisciplinary analysis from time to time. Martha C. Nussbaum, Still Worthy of Praise, 111 HARV. L. REV. 1776, 1782 (1998) (criticizing Posner's Holmes Lectures for mischaracterizing elements of academic philosophy); $c f$. Brian Leiter, Intellectual Voyeurism in Legal Scholarship, 4 YALE J.L. \& HUMAN. 79 (1992).

425. In re Roel, 144 N.E.2d 24, 28 (N.Y. 1957) ("When counsel . . are admitted to the Bar of the State ... they are responsible to the client ... to know the law of ... foreign State[s]."). For a discussion of changes in technology and publishing that make it easier to be a refined comparativist, see supra note 413. The difficulty in being a comparativist at all, however, does counsel in favor of refined comparativist judges sticking to formal legal texts. Supra note 4.

426. One example of this is "law canvassing," supra note 74, when a judge looks at the law of many states to make a particular conclusion. In a similar vein, for examples of cases interpreting one statute in light of other statutes from different jurisdictions, see, for instance, Lorillard $v$. Pons, 434 U.S. 575 (1978); and Cartledge v. Miller, 457 F. Supp. 1146 (S.D.N.Y. 1978). Some cases take this to an extreme: In Connecticut v. Doehr, 501 U.S. 1 (1991), the U.S. Supreme Court 
international business cases, ${ }^{427}$ and so are used to all forms of comparative legal reasoning. Indeed, many courts in the world are quite used to (and have been quite successful at) creating a body of integrated and coherent law that combines the laws of different jurisdictions; the European Court of Human Rights, for instance, and other supranational adjudicatory bodies around the world, are quite experienced at practicing comparative constitutional law. ${ }^{428}$ Being aided in this process by experts and by the arguments of litigants about comparative constitutional law, a judge will have a wealth of different resources and interpretations of comparative law to rely upon in reaching a decision. ${ }^{429}$

looked at the prejudgment attachment rules of all fifty states, comparing them and contrasting them at a very specific and nuanced level. Id. app. at 24-26.

Indeed, a true understanding of comparative knowledge demonstrates that Justice Scalia is not quite the opponent of using comparative constitutional law that he might at first glance appear to be. As discussed supra note 40, Scalia does use comparative constitutional law in some of his opinions. McIntyre v. Ohio Elections Comm'n, 514 U.S. 334, 381 (1995) (Scalia, J., dissenting) (suggesting that the prohibition of anonymous campaign speech in foreign democracies supports prohibition in the United States). Even beyond that, however, Justice Scalia has elsewhere advocated the use of original intent as the lodestar of constitutional interpretation. Scalia, supra note 391. Properly understood, original intention analysis is itself a form of comparative analysis (albeit a form of temporal comparativism rather than the geographical comparativism of refined comparativism).

427. Supra note 418. These are just some examples of how judges have already been performing comparative legal analysis. Judges also have been forced to interpret treaties from different jurisdictions, which involves not only interpreting a treaty but also other national laws that relate to treaties. Judges have also had to supervise discovery taking place in other countries. Euromepa S.A. v. R. Esmerian, Inc., 51 F.3d 1095, 1101 (2d Cir. 1995).

428. These courts that themselves have lots of experience in being comparativist could provide a wealth of knowledge for American courts utilizing the refined comparativist method.

429. There might be a possible distributive critique of refined comparativism. By making comparative constitutional law relevant to deciding constitutional cases, the cost of litigation increases. Litigants with fewer resources will not have the ability to effectively research comparative constitutional law, let alone hire experts or translators. This mirrors some of the debates about unpublished opinions having precedential value. Lauren K. Robel argues that not publishing opinions poses problems for poor litigants. She claims that wealthier litigants are more likely to know about unpublished opinions and thus are more likely to be able to spot trends invisible to litigants with fewer resources. Robel, supra note 90, at 946-55.

I have several thoughts about this criticism. First, lawyers will be able to find published and online copies of opinions and studies from the countries that will supply most of the comparative constitutional insight for refined comparativist judges. This is true for a number of reasons. First, the countries with the most extensive constitutional law are the most relevant under refined comparativism because they have compiled a lot of information about the operation of their constitutional rules. As it works out, the countries with the most constitutional data also are significantly more likely to make relevant materials widely available. Also, these countries with long constitutional traditions are most likely to be the ones relevant under refined comparativism because they have the fewest number of social and legal differences compared to the United States. So, countries like Germany, France, and even South Africa and India now publish their opinions in many places, as do scholars of their courts. 
Moreover, the refined comparativist judge is not doing all that much with comparative constitutional law. It is true that for a source of meaning to be persuasive in the way I have described comparative constitutional law, one must first understand the source. But remember, the refined comparativist judge is just making very broad rules ${ }^{430}$ and does not need to know everything about the constitutional law he or she is borrowing. Even when using American sources, judges do not know all that much. When the Warren Court decided Brown v. Board of Education, ${ }^{431}$ it may have known something about the South, but did it really know what would happen in the years following its decision? The refined comparativist judge is performing a similar task: announcing broad rules, and waiting to see how they actually work. The basic seed is coming from abroad; the seed is growing in American soil.

\section{CONCLUSION}

American constitutional law must enter the new century with a willingness to deal with a rapidly changing world. All around, countries are developing sophisticated judicial systems with talented judges who write cogent and compelling opinions. At the same time, at home, America is becoming a multicultural country unlike anything ever seen before on the planet. Will American constitutional law-particularly American constitutional scholarship_-deal with these changes, or will it remain in the last century?

Another response to this distributive concern would be to implement in constitutional adjudication what courts have done for other areas of American adjudication-allow court-appointed experts to play a larger role to make up for inequalities between parties, or have the courts actually help pay for individual litigants' experts. This will be complemented by the professionalization of comparative constitutional law discussed elsewhere in the Article. Supra text accompanying 105108. This would make relevant research materials more widely available.

A final response to the distributive critique of refined comparativism is that it seems to misunderstand the probable operation of refined comparativism. Constitutional cases that present challenging "hard cases" and that will lead to abstract rules (remember, of course, that refined comparativism requires a judge to be issuing a general principle if he or she is to use comparative constitutional law) will usually feature litigants who have lots of resources. Litigants in cases in which comparative constitutional law is relevant will disproportionately be wealthy and experienced because "hard cases" will almost always occur at the federal appellate and Supreme Court level.

430. The refined comparativist judge also has the power to be a "refined comparativst maximalist" or a "refined comparativist minimalist"-if the judge is worried about how little he or she knows about another country, or is worried about how using comparative constitutional law will translate into the American context, the decision can apply just to the facts of the one case before the court, the court can decide the issue but agree to revisit it anew to see how the use of comparative constitutional law worked, and so on. Supra note 90 and accompanying text.

431. 347 U.S. 483 (1954). 
Refined comparativism offers a workable system for the American judge of the new century. Because the law values experience over experimentation, especially at the appellate level, judges will be helped in becoming refined comparativists by the experience of foreign countries and by the (generally unrecognized) tradition of American constitutional opinions using comparative constitutional insights. As countries around the world continue to move towards liberal democratic constitutionalism, and judges at home inevitably look to these countries' insights, that reservoir of experience will only increase. Indeed, given the increasing contact between judges from around the world, and the increasing availability of comparative legal materials, citing to comparative constitutional law seems inevitable. It would be much better, therefore, to recognize this, and talk about when it might be helpful and when it might not be so helpful. Such is the agenda for the twenty-first century American constitutionalist-and I hope refined comparativism is a good start. 